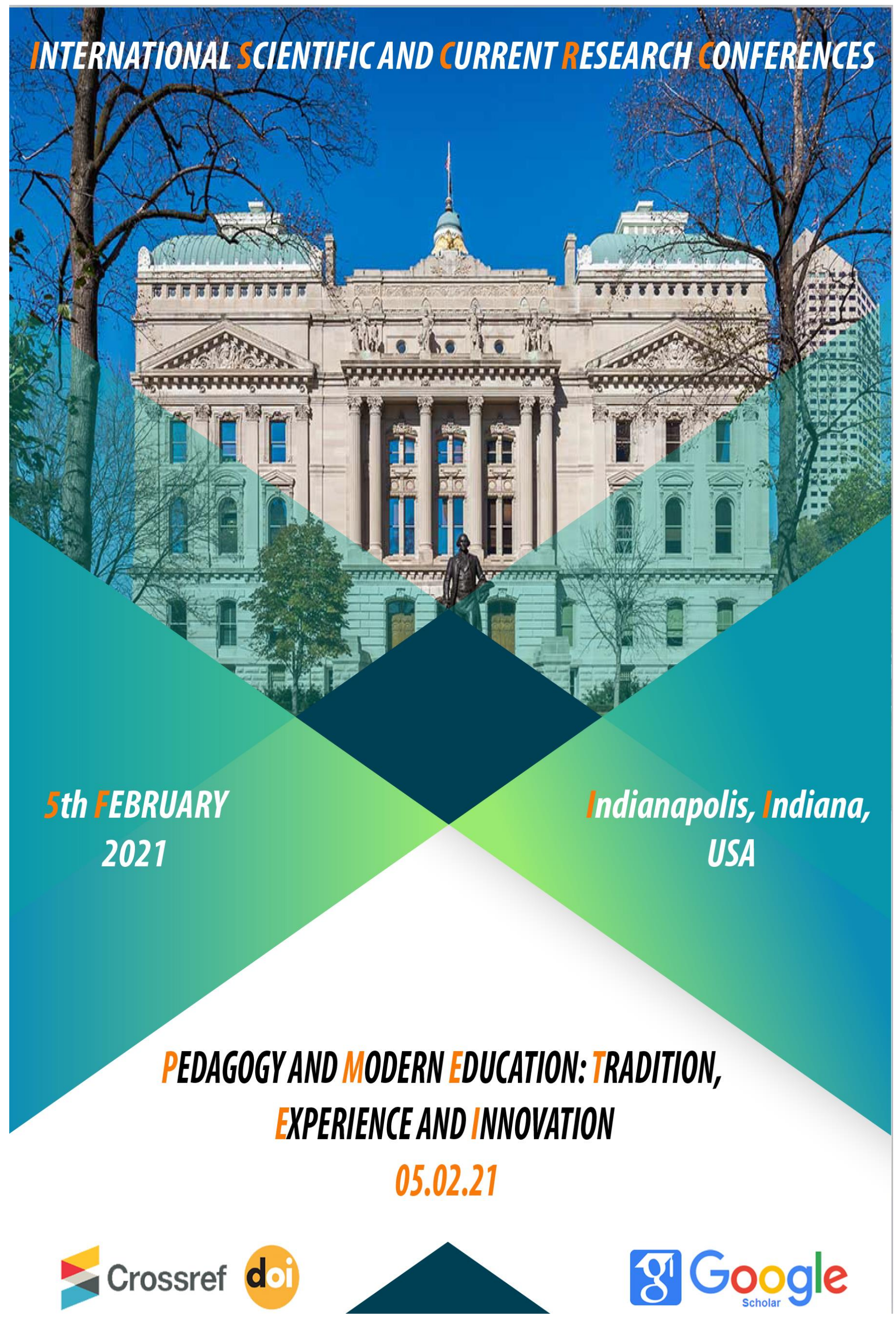




\section{INTERNATIONAL SCIENTIFIC AND CURRENT RESEARCH CONFERENCES}

“PEDAGOGY AND MODERN EDUCATION: TRADITION, EXPERIENCE AND INNOVATION"

\section{CONFERENCE DATE}

$$
\text { 05-02-2021 }
$$

DOI - https://doi.org/10.37547/iscrc-intconfo2

\section{INTERNATIONAL SCIENTIFIC AND CURRENT RESEARCH CONFERENCES}

Indianapolis, Indiana

$$
\text { USA }
$$

4 Crossref doi gil Google 


\section{PEDAGOGY}

Pedagogy, most commonly understood as the approach to teaching, is the theory and practice of learning, and how this process influences, and is influenced by, the social, political and psychological development of learners. Pedagogy, taken as an academic discipline, is the study of how knowledge and skills are imparted in an educational context, and it considers the interactions that take place during learning. Both the theory and practice of pedagogy vary greatly, as they reflect different social, political, and cultural contexts.

Pedagogy is often described as the act of teaching. The pedagogy adopted by teachers shapes their actions, judgments, and other teaching strategies by taking into consideration theories of learning, understandings of students and their needs, and the backgrounds and interests of individual students. Its aims may range from furthering liberal education (the general development of human potential) to the narrower specifics of vocational education (the imparting and acquisition of specific skills). Conventional western pedagogies view the teacher as knowledge holder and student as the recipient of knowledge (described by Paulo Freire as "banking methods"), but theories of pedagogy increasingly identify the student as an agent and the teacher as a facilitator.

Pedagogy is a term that refers to the method of how teachers teach, in theory and in practice. Pedagogy is formed by an educator's teaching beliefs and concerns the interplay between culture and different ways to learn. In order to help students to build on prior learning, meaningful classroom relationships must exist.

\section{EDITOR IN CHIEF}

Jayant Shah, National Institute of Education, Singapore 


\section{SUPPORTING EDITORS}

Sudarshan Panigrahi, The Maharaja Sayajirao University of Baroda, India Jean-Louis Derouet, Institut National de Recherche Pédagogique, Lyon,

France

Tomáš Janík, Masaryk University, Brno, Czech Republic

Mary Koutselini, University of Cyprus, Nicosia

Isabella Wong Yuen Fun, National Institute of Education, Singapore

Ana Moreno Núñez - Autonomous University of Madrid, Spain

Chua Boon Liang - National Institute of Education, Nanyang Technological

University, Singapore

Hairon Salleh - National Institute of Education, Nanyang Technological

University, Singapore

Kehk Bee Lian - National Institute of Education, Nanyang Technological

University, Singapore

Lam Bick Har - The Education University of Hong Kong

Leonel Lim - National Institute of Education, Nanyang Technological

University, Singapore

Loh Chin Ee (also Book Review Editor) - National Institute of Education, Nanyang Technological University, Singapore

Barbara Pieronkiewicz, Pedagogical University of Cracow, Poland Dilek Tanışlı, PhD, Anadolu University, Turkey

Dorit Patkin, PhD, Kibbutzim College of Education Technology \& Arts, Israel

Eyüp Artvinli, PhD, Eskișehir Osmangazi University, Turkey

Marcelo Afonso Ribeiro, PhD, University of São Paulo, Brazil

Maria Eduarda Duarte, PhD, University of Lisbon, Portugal

Mehmet Kandemir, PhD, Kırıkkale University, Turkey

Mustafa Güler, PhD, Trabzon University, Turkey

Olivera Đokić, PhD, University of Belgrade, Serbia 
1. Muhayyo Fakhriddin kizi Sultanova

2. Ethan $\mathrm{H}$.

3. Azizbek Yokubjonovich Nazarov

4. Aykan Asil M.

5. Farkhod Muhammadievich Alqarov

6. Khurshida Olimjonovna Pardaeva

7. M. Irfan Khan

8. Orifjon Naziralievich Usmankulov

9. Muborak Saidobdullaevna Salaeva, Nargiza Djurabaevna Salimova

10. Rustamjon Isoqov

11. Ilhom Akbarov, Murotbek Boydadayev, Madraximov Alloberdi Madraximov

12. Otabek R. JURABOEV

13. Aziza Bakhriddinovna Kobilova

14. B. F. Botirov, J. Usmonov, R. I. Ablyakimova

15. J.A. Djuraev, Sh.F. Fayozov

16. J.A. Djuraev, F.N. Norjigitov

17. Dilfuza Imomova, Shamsiya Imomova

18. Mirkomil Gudalov, Matluba Gozieva

19. Zilola Abduhakimovna Sanakulova, Mahfuza Sangirova
The Role Of Tour Bases In The Development Of Tourism In Uzbekistan

Psychology Towards Research Among Post Graduate In Business School (Bs), Canada

Classification Of Documents Of Turkestan Scientific Societies Kept In The National Archive Of Uzbekistan

Instructor Comprehension In Grammar Learning: A Report Of Turkish EFL Vocabulary

Energy And Environment - Environmental Protection

The Behavioral Role Of Hupotalamic And Sensamotor Posts In Specification

Classify And Authorize A Pedagogical Program Of Global

Citizenship Pedagogy In Foundational School Of Iran's

Scholastic Structure

Method For Separation Of Platinum From PlatinumContaining

$28-31$ Waste Solutions

Interrelationship Between Life Quality And Vegetative Nervous System In Patients With Asthma

Xiva - Museum Under Open Sky!

Optimal Technological Modes For Producing BitumenRubber Compositions

About The Decoration Of Manuscript Books Of The Timurid Period

Periphrases Used Instead Of Medicinal Plants Combination Of National Styles And Modern Innovations

Rhinoplasty In Combined Deformations Of The Nose

Features Of The Course Of Chronic Tonsillitis In Rhinosinusitis

$60-62$

Aydar-Arnasay Lakes System Soil Structure And Its Chemical Composition

Eco-Trail Routes In Zaamin National Park 
20. Nasiba Karshiboeva

21. Shakhnoza Akhmedovna Siddikova, Zukhra

Ziyatovna Yakhshieva

22. G.A. Sharipova

23. D. Rajabov, J.A. Djuraev

24. J.Kh. Razzokov, J.A. Djuraev

25. Marufjon Shodmonovich Moyliev, Husniddin Akrom Ogli Boboyorov

26. Sapura Mustafakulovna Nematova

27. Kh.Kholmurodov

28. Shohista Saydievna Ahmedova

29. Feruza Abdujalilova

30. I.Ergashev

31. Lola Akhrorova Iminovna

32. A.Sh. Kaipnazarov

33. Shahzoda Fayzullaeva

34. Umida Farxadovna Elmuratova

35. Allaberdiev R.X., Raximova M, Esov R.A.

36. Eshonkulova Surayyo Isomiddinovna

37. Primov Mukhiddinjon Omonovich

38. Javlon Karimjon O`G ' Li Zoilboev
Rare Plants In The Turkestan Range (Dzhizak Regions)

Republic Of Uzbekistan

Functional Literacy In Living Challenges (Pisa Study)

Developing Students' Multicultural Competencies Through Extracurricular Economic Education

Voice Functional Impairments In Children And Adolescents

$88-90$

Adenoiditis: A Modern Look In Diagnostics And Treatment

$91-93$

Central Bukantov Mineral Associations Of Gold Mining And

$94-96$

Their Composition (On The Example Of Kaskirtov, Boztov, Jelsay Fields)

A New Worldview In Alisher Navoi's Commentary

$97-98$

Transformation Of Farhad's Image In The Diwan "Bada'i

99-101 AlBidaya" By Alisher Nava'i

About A Poem

102-104

Features Of Phrases In Uzbek Language

Issues Of Introduction Of E-University In The Context Of Rapid Development Of Digital Technologies

About Togay Murad's Novel "The Fields Left By My Father"

111-114

Stages Of Development Of Interaction Between Society And

115-117 Nature In The Soviet Period (Late Xx - Early Xxi Century)

Increasing The Responsibility Of Lawyers And Ensuring The Human Right To Professional Legal Assistance

The Modernization Of Education System In Uzbekistan Is A Actual Problems In Public Policy

Morpho-Biological Properties Of Hibiscus Syriacus L. And Hibiscus Hybrid

Artistic Interpretation Of Events In Nadira Poetry

129-132

On The History Of Training Of Cartographers In Uzbekistan (20s-30s Of The XX Century)

Requirements For The Adoption And Administration Of An Administrative Document (Act) By Public Administration Bodies 


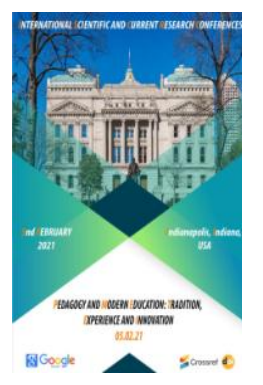

\title{
The Role Of Tour Bases In The Development Of Tourism In Uzbekistan
}

\author{
Muhayyo Fakhriddin kizi Sultanova \\ Lecturer at the Department of Design Faculty of Design The National Institute of Art and \\ Design named after K.Behzad
}

\section{ABSTRACT}

As a result of the special attention paid by the head of our state to the tourism sector, the tourism potential of our country is growing. New modern hotels and resorts are being built. New tourist routes are being developed and services are being improved. This will be an important factor in expanding the flow of foreign tourists to our country, the development of domestic tourism, the creation of new jobs and increasing the welfare of the population. This article also discusses the level of tourism in Uzbekistan and the role of tourist destinations in it.

\section{KEYWORDS}

Camp, tourism, service, ecotourism, geotourism, recreation, zone.

\section{INTRODUCTION}

Our country is among the top ten countries in the world for the number of historical monuments. There are more than 7,000 architectural and archeological monuments in our country, and such a priceless heritage is the inexhaustible wealth of our people.
The nature of our country is very colorful and unique. There are majestic mountains, steppes, rivers and lakes. It is important in the development of ecotourism, the organization of interesting trips, increasing the tourism potential of the region. 
Extensive work is being done to promote these opportunities, to improve the activities of resorts and tourism organizations, and to implement targeted programs based on the specifics of each region, its internal capabilities. For example, extreme tourist services such as ecotourism, geotourism, offroad trips, mountaineering and rafting in mountainous areas are organized. In addition, the Republic of Karakalpakstan, Navoi, Jizzakh and Khorezm regions have built a number of camps, camps, recreation and health facilities. New tourist routes have been established along the Ugam-Chatkal State National Nature Park, the shores of the Amudarya and Aydarkol lakes, the Kyzylkum Desert, the Nurata and Boysun mountain ranges.

Today, in accordance with the regional programs approved by the Cabinet of Ministers of the Republic of Uzbekistan, the development of tourism continues. Projects aimed at restoring cultural heritage sites, construction and repair of tourist facilities, development of new tourist routes, diversification of tourist products, promotion of tourism potential of the country are being implemented. We know that in the field of tourism, its rapid development and the development of tourism activities also depend on the activities of the hotel.

In our country, too, attention has been paid to the development of these aspects since the early days of independence, and today tourism has risen to the level of the main state policy. In this regard, President Sh.M.Mirziyoev said: "We have now approved only the issues related to the structure, which deals with the development of tourism. These measures should be strengthened by concrete measures to increase the contribution of tourism to the development of the Uzbek economy, to promote our historical and cultural values, as well as to replenish foreign exchange reserves."
Our country pays attention not only to the above-mentioned tourism, but also to the number of hotels and tourist attractions in order to increase the flow of tourists to our country and provide them with quality services and leisure. We can see many examples of this so far. Not far from the capital, we can cite the example of several hotels and tourist attractions in the mountainous areas of Tashkent region alone. Another proof of this is the mountain resort zone "Amirsoy", opened in the mountainous area of Bostanlyk district of Tashkent region, $80 \mathrm{~km}$ from the city of Tashkent.

\section{METHODS}

One of the most important steps in the development of tourism in Uzbekistan is the design of tourist attractions and bringing them up to world standards. For this purpose, in the design of tourist attractions:

- Increasing the role of tourist destinations in the tourism industry of Uzbekistan;

- Expansion of tourist attractions and their demand in cities and regions with historical and cultural heritage;

- To study the factors influencing the development of the tourist area;

- Analysis of the state of development of tourist attractions in Uzbekistan and increase the efficiency of existing tourist attractions;

- Creation of tourist attractions in accordance with the requirements of urban planning and architectural design;

- When designing a tourist attraction, special attention should be paid to the development of modern architectural and interior design solutions.

A tourist base is a tourist complex in the direction of active transport, which includes facilities for active recreation of tourists. Tourists are usually attracted by active means of transport: mountains, water, skiing, travel. As a rule, tourist camps are important because 
they are located in beautiful places, along ravines, rivers and lakes, on the edge of the forest. Unlike year-round accommodation hotels, tourist camps can be year-round and seasonal. Tourist bases differ in terms of location, living conditions, type and quality of services provided. One of the distinguishing features of tourist camps from hotels is the presence or absence of breakfast, lunch and dinner. The package of additional services of tourist camps depends on the consumer and to whom it is directed, but mainly these services are traditional: restaurant, bathroom, swimming pool, guarded parking, for various sports sports grounds, sometimes beauty salons, massage rooms, tourist services.

The essence of the task of planning (designing) a tourist area is to develop a model of the tourist and recreation system the location of interconnected tourist facilities and infrastructure, the development of tourist routes, and so on. The main objects of design are tourist and recreational facilities, enterprises and organizations, tourist and supply infrastructure. The placement of design objects is based on a comprehensive assessment of the potential of the area, taking into account the geographical, architectural, planning, engineering and environmental conditions. Tourist attractions can have from 100 to 500 rooms, usually far from the city and near the reservoirs, located in beautiful places, which increases the interest in it and the flow of tourists. Tourist attractions offer a full range of services: many sports facilities, including playgrounds.

The interior of the building depends on the composition of the buildings of each major functional group, such as the seating area, level of comfort, number of floors and location. Internal communications include vertical (elevators, stairs) and horizontal (corridors) connections. For residential buildings, the internal height connection includes service elevators for the transport of servants and goods, which can be combined into an autonomous transport center with access to spaces from service corridors Corridors - accommodation - Horizontal connection on residential floors - provides communication between residential buildings. An important element of the functional relationship of all groups of rooms is the vestibule, which forms the main stream of vacationers. The vestibule is the main communication center that provides connections to residential floors, dining areas and office rooms. The functional organization of the main groups of buildings determines their planning decisions and shapes the architectural and spatial composition of the recreation facility building.

\section{RESULTS}

The decision of the recreation zone on urban planning should be based on a comprehensive plan for the development of the national economy in the region, taking into account the progressive directions of development of all its components and ensuring the protection of recreational resources in the region. The functional typology of a tourist institution and its associated architectural and compositional solutions are as follows:

- The first category: buildings of modern architectural form, taking into account the characteristics of the natural landscape, using modern materials and structures on the basis of individual or custom design. These types include almost all tourist hotels and city motels.

- The second category: regional architecture, modern and national forms of synthesis of new buildings of tourist institutions using the basic principles and ethnographic architectural forms. These types include tourist camps, camps, one-day shelters, huts, youth camps.

- The third category: old, adapted buildings for tourist facilities of historical or ethnographic 
significance; buildings that fully replicate the forms and methods of regional architecture while preserving new traditional materials and structures.

- The fourth category: type of seasonal or mobile buildings and structures (tents, caravans, tourist ships, trains).

- The fifth type: tourist buildings and structures, attractive and traditional in form and style.

The interaction of the buildings of tourist facilities with the natural environment creates optimal conditions for the creation of landscapes, integrated architectural and spatial compositions and the organization of various forms of tourism, which ensure the preservation of the most valuable nature.

The architectural and planning structure of tourist hotels is influenced by their location in cities, rural recreation and tourist zones and specialized sports and wellness zones.

\section{DISCUSSION}

Today, architects around the world are looking for new ways to combine the uniqueness of architectural and compositional solutions of buildings and recreation complexes with the requirements of maximum industrialization. The application of a radically new style of design - the variability of the spatial planning elements of buildings allows resorts to solve this problem.

As a result of the collected data and research, we can see that the demand for camps is growing in our country. In this case, the main document and reference tool used in the design of the camps is the QMQ, which is used in construction in our country. According to it, the buildings of the Republic of Uzbekistan are divided into four levels according to the normal service life: the service life of buildings of the first level is more than 100 years; Level II from 50 to 100 years; III degree from 20 to
50 years; Level IV is 5 to 20 years. Another important requirement for buildings is fire safety.

In addition, in order to achieve promising results in this area, it is possible to effectively use the experience of tourism in developed countries and many scientists and famous architects who have conducted research in this area. Decree of the Republic of Uzbekistan "On measures to ensure the accelerated development of tourism"; Decree of the President of the Republic of Uzbekistan dated February 3, 2018 No PF-5326 “On additional organizational measures to create favorable conditions for the development of tourism potential of the Republic of Uzbekistan"; Resolution of the President of the Republic of Uzbekistan dated August 16, 2017 No PP-3217 "On priority measures for the development of tourism in 2018-2019" can also be used as a normative document.

\section{REFERENCES}

1. Decree of the President Shavkat Mirziyoyev dated December 2, 2016 "On measures to ensure the accelerated development of tourism in the Republic of Uzbekistan."

2. Qurbonov J.M., Mamarasulov Z.E., Qurbonov J.J. Lecture course "Organization of the hotel industry" Part I. -S .: SamISI 2011y.

3. THE ROLE OF FURNITURE IN THE FORMATION OF THE RESTAURANT'S INTERIOR:. (2020). International Engineering Journal For Research \& Development, 5(9), 5. Retrieved from http://iejrd.com/index.php/

/article/view/1450.

4. Mukaddaslsakova.(2020).Influence of Colors On Children's Mentality In Children's Institutions, Research And Analysis of Psychologists And Designers. International Journal of Scientific \& Technology Research, 9(2), 5549-5551. 
Published: February 05, 2021| Pages: 1-5

5. Qizi, A. N. X., \&Nazokatkhon, A. (2020). Factors influencing the creation of a comfortable microclimate and environmental control of zone by landscape design. ACADEMICIA: An International Multidisciplinary Research Journal, 10(5), 2040-2049.

6. Sh. F.Tursunova. (2020). HISTORY OF ADVERTISING IN UZBEKISTAN. International Engineering Journal For Research \& Development, 5(9), 10. https://doi.org/10.17605/OSF.IO/TFA5Z

7. Southern mesopotamia in the first half of the 3 rd millennium bc MI Razikberdiev - Asian Journal of Multidimensional Research (AJMR), 2020

8. Formation of Landscape Design in Japan OS Kasimov - European Journal of Business and Social Sciences, 2018

9. Sayfullaev, N. Current Issues on Fine ARTS Education: Continuity and Prospects for Development. Religación, 4, 192-194.

10. Абдурашидовна, Қ. Д. (2020). АЭВИД ФОНДИ ВА КОЛЛЕКЦИЯЛАРИДАГИ ЎЗБЕКИСТОННИНГ X АСРИГА ОИД АШЁЛАР ВА УЛАРНИНГ ЎЗИГА ХОС ХУСУСИЯТЛАРИ. Маданият чоррахалари, 4(2). 


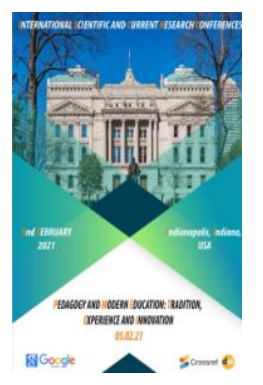

\section{Psychology Towards Research Among Post Graduate In Business School (Bs), Canada}

\section{Ethan $\mathrm{H}$.}

Department Of Business Management University Of Alberta Public University In Edmonton, Canada

\section{ABSTRACT}

This investigation set out to look at the Masters understudies' mentalities towards research part of their program. It was directed in (BS) in Canada. A phenomenological subjective examination approach was utilized. The respondents had the option to portray their accounts on their own experience when undertaking research. The choice of the 17 respondents who partook in this investigation was finished utilizing purposive procedure. To be chosen as a respondent in this examination, one must be an understudy of BS seeking after a MBA program and needed to have finished the coursework segment of their work yet had deferred in the program because of inability to finish their exploration part as expected. The understudy needed to in any case being occupied with research without having looked for a "dead period", an authority time of withdrawal before resumption, or having inside chosen to offer the course a reprieve. The discoveries uncovered that the understudies' mentalities towards research was fundamentally affected by oversight, the understudies' own capacities and their new climate now and again causing uneasiness and inconvenience. Thinking about the outcomes, it is suggested that the Business school be adaptable as far as determination of directors and furthermore concoct satisfactory direction program on exploration.

\section{KEYWORDS}

Attitude, MBA, exploration, and course work part, graduate investigations

\section{INTRODUCTION}

Individuals go through an interaction of deciphering their experiences with their current circumstance which frames a psychology. In this manner, they structure 
alternate points of view which may upgrade or diminish their advancement. This takes the psychological, full of feeling and conduct points of view, to deliver a psychology towards articles, individuals, or occasions. Inspirational mentalities are a pointer that an individual being referred to, accepts that what they are occupied with is beneficial. Such a psychology in this manner, serves to produce positive energies and inspiration to seek after guaranteed.

\section{INSTRUMENTS}

A meeting guide was set up to help in information assortment. The guide contained a bunch of foreordained inquiries that for the most part pointed toward evaluating the understudies' encounters and their decisions towards the equivalent. It likewise gave space to additional examining.

\section{METHODOLOGY}

The investigation included leading eye to eye meet with every respondent at their particular time. All the meetings were directed inside the college BS. The normal time went through with every interviewee was one and a half hours. Upon demand, all the respondents acknowledged to have the meetings recorded was finished utilizing advanced cells. One of the two questioners would take short notes predominantly on the respondents' nonverbal signals that couldn't be caught by the PDA.

\section{RESULTS}

Various issues were progressed as significant variables that impacted the understudies'

demeanor as explained under the accompanying subheadings:

Producing a Research Topic
As indicated by the respondents, apprehension overwhelms the time of concocting a subject. Lion's share of the respondents contended that they scarcely had a thought of a fitting exploration point. Surely, a large number of them had more than three examination subject thoughts yet upon investigation they later discovered that couple of would pass for a researchable point. At one point a few understudies would get disappointed after all the themes they had at the top of the priority list were dismissed by their managers. To some this took them over a time of two months.

\section{CONCLUSION}

This examination set out to inspect the disposition of the exploration segment of the understudies seeking after alumni learns at BS. The 17 chose respondents gave an understanding of how they felt and noticed that uneasiness, sensations of forlornness and being focused by either the directors or the choices made by the personnel of graduate investigations cause them to have low confidence and not appreciate the entire interaction of exploration.

\section{REFERENCES}

1. Ahan, H. and Mohemmad, D. (2006). Grasp beginning slowed down exploration understudies. Creative Higher Education Systems, 29(5), 248-256.

2. Aniney, L. (2012). Maintenance and ideal graduation team report submitted May 2012.

3. Jils, K. (2009). Administrators' originations of examination and the ramifications for manager advancement. Worldwide Journal for Academic Development, 10 (2), 185-198.

4. Consumes, U. and Groves, T. R. (2009). The act of nursing research: lead, 
PEDAGOGY AND MODERN EDUCATION: TRADITION, EXPERIENCE

AND INNOVATION - INTERNATIONAL CONFERENCE

Published: February 05, 2021| Pages: 6-8

scrutinize, usage (seventh Ed.)

Philadelphia, PA: Elsevier Saunders. Kvale, S. also, Brinkmann, S. (2007).

5. Y. (2015). Worldwide students" challenges in scholarly composition: A contextual investigation from a conspicuous U.S. College. Diary of Language and Linguistic Studies, 53(5), 408-419.

6. Choudhary, K. G. Cheung, O. H., and Li, A.C (2007). An investigation on the impression of understudies towards instructive weblogs. Worldwide Journal of Informatics in Education Systems, 6(3), 533-554. 


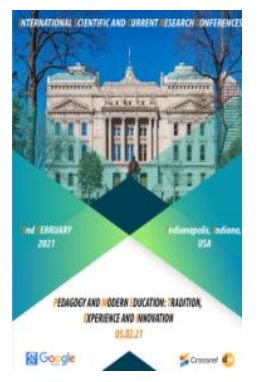

\title{
Classification Of Documents Of Turkestan Scientific Societies Kept In The National Archive Of Uzbekistan
}

\author{
Azizbek Yokubjonovich Nazarov \\ Senior Lecturer Department of Source Studies and Archival Studies Faculty of History, \\ National University of Uzbekistan
}

\section{ABSTRACT}

This article is devoted to the study of archival funds kept in the National Archives of Uzbekistan by scientific societies operating in the Turkestan region in the late XIX - early XX centuries. The article examines the status of documents that contain information about the emergence and activities of scientific societies. The condition of the papers in the archives is analyzed.

\section{KEYWORDS}

Governor-General of Turkestan, society, National Archive of Uzbekistan, fund, list, storage unit, document, print, manuscript, paper.

\section{INTRODUCTION}

Document analysis is one of the most widely used effective methods of gathering basic information. Documents at various levels contain information about the results of human activities. Valuable information can be obtained during the study of archival documents.

Documents of scientific societies operating in the Governor-General of Turkestan are stored in the National Archive of Uzbekistan [1]. In particular, the $1-69$ Foundation is the Turkestan branch of the Russian Imperial Geographical Society. The fund contains documents on the activities of the society in 1896-1927 [2]. It consists of a total of 84 storage units.

I-71 Foundation - Turkestan Amateur Archaeological Circle. The I-71 fund consists of 
30 compilation volumes combined into a single list [3], and chronologically, the documents in the fund cover the years 18951917. The collection includes documents related to the formation and activities of the club: its charter, list of club members, minutes of meetings, correspondence with local researchers, metropolitan and foreign researchers, reports on the activities of the club [4].

I-103 Fund - Fund of Turkestan Agricultural Society. The society operated from 1885 to 1921. The fund contains the company's charter, minutes of board meetings, statements and reports on the company's activities. The fund also includes correspondence of the society on various issues, a list of members of the society, estimates and similar documents. It consists of a total of 317 storage units [5].

\section{THE MAIN FINDINGS AND RESULTS}

Fund I-361 - Tashkent branch of the Imperial Society of Oriental Studies. The fund contains information from 1901 to 1917, that is, until the department ceased to exist. It consists of a total of 13 storage units. The activities of the department consisted mainly of organizing and conducting various presentations at the meetings of its members [7].

I-591 Foundation - Central Asian Scientific Society. From the point of view of archival sources, the fund I-591 contains documents from 1869 to 1972, ie the period of the society's activity. It consists of a total of 6 storage units [8]. They are included in a list.

Documents in the funds can be divided into the following groups:

- print (protocols, decisions, reports and scientific and methodological publications, work plans, letters of government and local authorities);
- Manuscript (conclusions, graphs and agreements, draft letters).

- It is expedient to study the archival funds of the scientific societies operating in the Governor-General of Turkestan in the following groups.

- The first group - decrees, laws, orders, circulations, resolutions, orders, decisions, instructions, guidelines, etc. on documents.

- The second group - instructions, programs, regulations, charters, contracts, estimates and other documents.

- The third group - reports, minutes, acts, operational information, newsletters, statistics, minutes of meetings.

Among the above, the reports themselves can also be divided into several categories. For example, shorthand reports, reports, cartograms, diagrams.

When analyzing the status of paper documents in the archives, it is necessary to pay attention to their paper, ink, writing instruments.

Most documents, such as a brief historical essay, report, financial report on the activities of the company, consist of accounts produced in a special printing house with a tabular view, $27 \mathrm{~cm}$ long and $23 \mathrm{~cm}$ wide. There were also small sheets of $12 \mathrm{~cm}$ long, $22 \mathrm{~cm}$ wide and 16 $\mathrm{cm}$ wide and $13 \mathrm{~cm}$ wide. The papers are 17.5 $\mathrm{cm}$ long and $12 \mathrm{~cm}$ wide. The size of the documents in the funds varied. For example, $22 \mathrm{~cm}$ long and $19 \mathrm{~cm}$ wide; length $18 \mathrm{~cm}$, width $21 \mathrm{~cm}$; length $28 \mathrm{~cm}$, width $22 \mathrm{~cm}$; length $35 \mathrm{~cm}$, width 23; length $21 \mathrm{~cm}$, width $15 \mathrm{~cm} ; 27$ $\mathrm{cm}$ long and $23 \mathrm{~cm}$ wide.

The letter from Berlin was $29 \mathrm{~cm}$ long and 21 $\mathrm{cm}$ wide. Most of the letters from abroad were typed.

Archival document papers are quality white papers produced in the 19th century. The 
signatures of the officials in the order, extract from the order, protocol, report types of documents are written in ink. Inks are found in blue, black. We can see that some telegram documents were signed in red ink.

Dark gray, blue, purple, and black rags were used in archival documents. Most of the documents are handwritten, some of the documents in the fund are typed. The purple text of the typewritten documents was not well preserved, blurred and invisible, while the black text was well preserved.

There are also assemblies that have been replaced with modern covers by the refurbishment department, but have not been repaired, as the storage condition and covers of the assemblies are much older.

When archival collections were analyzed from the outside, the collections of most collections were thick and well preserved, with a thickness of $0.3 \mathrm{~cm}$, a length of $38 \mathrm{~cm}$, and a width of $23 \mathrm{~cm}$, while the blue entries were blurred and the black entries were clear and well preserved [10].

\section{CONCLUSION}

Among the documents belonging to the scientific community in Turkestan, typewritten documents make up more than manuscripts. The first typewriters appeared in 1887 after the invention of the typewriter. After that, many valuable documents began to be typed. The uppercase letters in the typewritten texts of the Turkestan Scientific Society are $0.3 \mathrm{~cm}$, and the lowercase letters are $0.2 \mathrm{~cm}$ (corresponding to the current 14-point font of Microsoft Word).

According to source scholars, "any document can be a source of information about the past" [11] or "an archival document can be a historical source when it is popular and popular and can be used without hindrance" [12]. Therefore, the analysis of archival source studies of archival collections today should be reflected in research.

REFERENCES

1. Nazarov, A. Y. (2019). The fund of National Archive of Uzbekistan about the scientific institutions in Turkestan. ISJ Theoretical \& Applied Science, 10 (78), 587-589

2. Nazarov, A. Y. (2020). Scientific societies in the Turkestan governorate-general as an instrument of colonial statehood (archival source study). Journal of Critical Reviews, 7(7), 1068-1073.

3. ЎзМА. И-71-фонд, 1-рўйхат, 3-орқа варақ.

4. Nazarov, A. (2020). History Of The Emergence And Development of Scientific Societies In The GovernorGeneral Of Turkestan. The American Journal of Social Science and Education Innovations, 2(10), 82-88.

5. Nazarov, A. (2020). Analysis of historical and geographical research conducted in the governor-general of Turkestan. ACADEMICIA An International Multidisciplinary Researc $h$ Journal issn: 2249-7137 Vol. 10 Issue 11, November 2020 Pp. $865-870$ DOI: 10.5958/2249-7137.2020.01386.5

6. ЎзМА. И-з61-фонд, 1-рўйхат, 1йиғмажилд, 3-варақ.

7. Путеводитель. Центральный государственный исторический архив УзССР. Сост. Агафонова 3.И., Халфин Н.А. -Ташкент, 1948. С-144.

8. ЎзМА. И-591-фонд, 1-рўйхат, 1-варақ.

9. ЎзМА. И-69 фонд, 1-рўйхат, 5йиғмажилд, 102-103- варақлар.

10. ЎзМА. И-69, И-71, И-103, И-369, И-591 фондлар йиғмажилдлари тахлили.

11. Медушевская О. М. Источниковедение: теория, история, метод. - М.: Рос. гос. гуманит. ун-т, 1996. - С. 80.

12. Козлов В. П. О некоторых современных теоретико-методологических 
PEDAGOGY AND MODERN EDUCATION: TRADITION, EXPERIENCE

AND INNOVATION - INTERNATIONAL CONFERENCE

Published: February 05, 2021 | Pages: 9-12

проблемах архивоведения и

источниковедения. // Отечественные архивы. - М: 1995. № 2- С. 5-9.

13. Назаров, А. Ё. (2016). Организация использования документов Центрального Государственного архива кинофотофонодокументов Республики Узбекистан. Документ. Архив. История. Современность.-Екатеринбург, 2016, 484-489.

14. Adilov, J. K. (2019). THE CAMPAIGN OF ALEXANDER BEKOVICH-CHERKASSKY IN THE WORKS OF VV BARTHOLD. Theoretical \& Applied Science, (10), 572574.

15. Саидбобоев, 3. А., Рахмонкулова, 3. Б., \& Адилов, Ж. Х. (2016). Подготовка кадров архивистов в Узбекистане. Документ. Архив. История. Современность.-Екатеринбург, 2016, 514-518. 


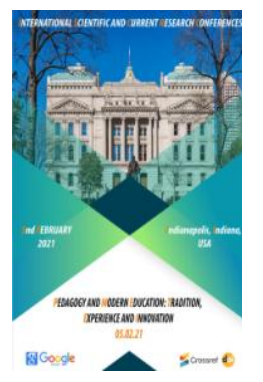

\section{Instructor Comprehension In Grammar Learning: A Report Of Turkish EFL Vocabulary}

Aykan Asil M.

Department Of Learning And Education Istanbul Okan University In Istanbul, Turkey

\section{ABSTRACT}

This Language Instructor Comprehension (LIC) study primarily explores language Instructors' beliefs and practices about a common Advised Second Language Procurement (ASLP) construct: Grammar Learning (GL). This study also aims to investigate to what extent Instructor beliefs and practices compromise with each other and cognitive and contextual factors behind their comprehension. The data were collected through interviews, observations, and stimulated recall with the Instructors. The findings after a cross-case analysis revealed that course book-based beliefs, experience-based beliefs, lack of theoretical knowledge and inclination for communicative activities influence what Instructors believe about GL. There are both congruent and incongruent relationships between beliefs and practices varying from one Instructor to another due to the effect of experiential knowledge, unconscious decisions, and some contextual factors. The findings can contribute to the integration of LIC into ASLP studies, and to LIC framework by exploring the effects of many variables on Instructors' decision-making processes.

\section{KEYWORDS}

Language Instructor comprehension (LIC), grammar learning (GL), Instructor beliefs(IB), Instructor practices(IP).

\section{INTRODUCTION}

Language Instructor comprehension studies drew substantial attention especially in the last 25 years, and the number of studies conducted in this research domain has dramatically increased. Instructor comprehension as a theoretical framework refers to a complex combination of knowledge, beliefs and thoughts hold by 
PEDAGOGY AND MODERN EDUCATION: TRADITION, EXPERIENCE AND INNOVATION - INTERNATIONAL CONFERENCE

Published: February 05, 2021 | Pages: 13-15

language Instructors regarding their instructional decisions and actions (Borg, 2006). It is also foregrounded that this complex cognitive activity of Instructors has its roots from their experience-based, personalized and context- sensitive perspectives and attitudes (Farrell \& Lim, 2005). On the basis of this complexity, the relationship between Instructors' beliefs and their instructional practices has been the interest of many studies in the field of Language Instructor Comprehension (LIC).

There is lack of generalizability in L2 learning studies in terms of the outcomes because of several factors including learning styles, individual learner differences, power relationships, gender identities, religious beliefs and more (Long, 2017). Hence, the problem of generalizability requires examining other confounding variables such as Instructors, their beliefs and their learning more closely to have a deeper understanding of each instructional context and specific instruction that is implemented in that context. The inclusion of Instructor comprehension into grammar learning studies can be beneficial in that Instructors' epistemological beliefs shape the way they teach grammar, and it may be unlikely to change these beliefs with Instructor education or research findings without creating an awareness and reflection opportunity to revise the aforementioned beliefs (Basturkmen, 2007; Borg, 2011). Thus, this study will offer a learning context to be analysed on the basis of grammar learning to bridge the gap between ASLP and LIC.

\section{METHOD}

Research Participant and Data Collection

This study was conducted at a preparatory school of an English medium instruction university in Turkey. The preparatory school where the study was carried out hosts more than 1000 students. The lessons, 24 hours per week, include integrated skills taught under the title of main course, which means all skills including reading, writing, speaking, listening, grammar and vocabulary are taught by means of a course book and complementary packs. 24 main course lessons are shared by three Instructors for each class, and these Instructors are expected to keep up with each other and complete the requirements of the weekly and monthly lesson plans. Additionally, these Instructors complete 24 hours of learning in a week in different classes.

\section{INSTRUMENTATION}

Selection of a small sample consisting of particular units of analysis and the aims of the study led me to use a qualitative case study methodology by employing cross-case analysis (Creswell, 2007; Merriam \& Tisdell, 2016). Case study methodology was chosen because it provides a chance for in-depth investigation of a contemporary social phenomenon within the context where the phenomenon and context are bounded (Yin, 2018). Likewise, case study methodology helps researchers to collect data considering the need for in-depth analysis of the multi-faceted aspect of the reality that is related to the context itself (Yin, 2018). For this reason, descriptive, explanatory, and exploratory research questions constitute the skeleton of this study in order to meet the requirements of case study methodology, which aims to have a holistic and naturalistic perspective towards individuals, group practices, and institutional processes and policies (Yin, 2018).

\section{FINDINGS}

The findings inform about these four EFL Instructors' beliefs, practices and contextual factors influencing their beliefs and practices of grammar learning in accordance with convergences and divergences among them. This cross-case analysis aimed to provide a more comprehensive framework that can enable us to compare what the Instructors 
PEDAGOGY AND MODERN EDUCATION: TRADITION, EXPERIENCE AND INNOVATION - INTERNATIONAL CONFERENCE

Published: February 05, 2021 | Pages: 13-15

working in the same institution believe and practise, and to what extent contextual factors affect these beliefs and practices.

\section{CONCLUSION}

To conclude, this study aimed to provide a particular perspective towards what language Instructors believe concerning L2 grammar learning, how they perform considering their stated beliefs and cognitive and contextual factors influencing their instructional decisions in order to contribute to the growing body of research conducted both in SLA and in LIC. This study also intended to bridge the gap between SLA and LIC by providing a reflection of how theoretical knowledge is perceived by language Instructors and to what extent their implementations are aligned with what SLA suggests. As a possible contribution LIC, this study aimed to offer a comprehensive framework to have a better understanding of Instructor comprehension rather than relying on a single variable. In this sense, I paid attention to consider the variables studied in the literature such as learning experience, previous language learning experience, and educational background. Selection of participants within the scope of these variables enabled me to compare and analyse the effects of these variables together compared to the studies focusing on the impact of a single variable.

\section{ACKNOWLEDGEMENTS}

I would like to extend my special thanks to the participant Instructors for helping me to conduct this study. They willingly shared their valuable time for the interviews and observation sessions, which made it possible to conduct this study. Also, I would like to thank the anonymous reviewers for their comprehensive and constructive feedback that guided me to improve the manuscript.

\section{REFERENCES}

1. H.Andre, O. P. X. (2009). The effects of implicit and explicit instruction on simple and complex grammatical structures for adult English language learners. Tesl-Ej, 12(3), 1-15.

2. Aslan, X. (2007). Instructor beliefs and Instructor training. The Instructor Trainer, 23(1), 12-32.

3. Basturkmen, X., Loewen, H., \& Ellis, k. (2005). Instructors' stated beliefs about incidental focus on form and their classroom practices. Applied Linguistics, 26(3), 443-472.

4. Borges, I. (2004). Studying Instructor comprehension in second language grammar learning. System, 30(2), 20-32. 
PEDAGOGY AND MODERN EDUCATION: TRADITION, EXPERIENCE AND INNOVATION - INTERNATIONAL CONFERENCE

Published: February 05, 2021 | Pages: 16-18

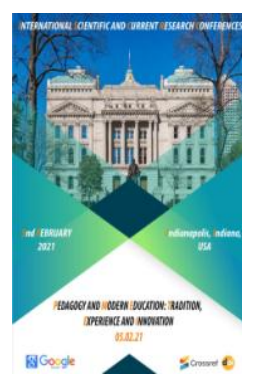

\author{
Energy And Environment - Environmental Protection \\ Farkhod Muhammadievich Alqarov \\ Lecturer Of Academic Lyceum Of Jizzakh State Pedagogical Institute, Uzbekistan
}

\title{
ABSTRACT
}

Energy, electricity, power plants, environmental impact, thermal energy. Within all sectors of the economy, such as oil, gas, coal, and nuclear energy, energy has a major impact on the environment. He grew at an incredible rate, and his strength increased. The growing demand for electricity can now be met in a variety of ways: a sharp increase in coal, oil and gas production, or the rational and integrated use of extracted resources.

\section{KEYWORDS}

Energy and environment petroleum products fluorine.

\section{INTRODUCTION}

The impact of energy on the environment is very diverse and is mainly determined by the types of energy devices. World practice shows that energy, chemistry and other sectors of modern production cannot be absolutely harmless. Human demand must be met with minimal impact on the environment and without harm to one's health. Undoubtedly, the use of solar and wind energy among energy sources is the most environmentally friendly.

1. In the structure of thermal energy, electricity generation, thermal power plants currently occupy a leading position. One third of the fossil fuel mined in MHD goes to this network. This is not only converted into energy in the process of burning fossil fuels, but also into millions of tons of sulfur oxides, 
PEDAGOGY AND MODERN EDUCATION: TRADITION, EXPERIENCE AND INNOVATION - INTERNATIONAL CONFERENCE

Published: February 05, 2021| Pages: 16-18

nitrogen dioxide, dry matter and more. About $14 \%$ of this is released into the atmosphere.

The sewage water of thermal power plants is polluted with wastes of technological cycles, containing vanadium, nickel, fluorine, phenols and petroleum products, which change the quality of water in the basin and affect aquatic organisms when they are discharged into water bodies.

2. The problems of nuclear energy, nuclear energy are now worrying millions of people. Different opinions are expressed. Some are in favor of further developing it in the future, while others are. They are proposing to eliminate all nuclear power plants. Such offerings have increased especially since Chernobyl and the disaster.

Nuclear power accounts for $25 \%$ of the world's electricity generation. Electricity generation at nuclear power plants is an environmentally friendly source and today is the only way to generate energy without emitting greenhouse gases. NPPs have a number of advantages:

a) In many countries, the energy produced by nuclear power plants is much cheaper than the energy produced at other stations (burning oil, gas and even coal);

b) countries with nuclear power plants fully meet their domestic energy needs;

c) The use of nuclear energy ensures the rational use of fuels such as oil, coal and gas, which are valuable raw materials for industry:

d) Nuclear energy is one of the most environmentally friendly sources, if they work well, its impact on the environment is much less than other sources.

Since the advent of nuclear power plants, there have been four major nuclear accidents: a reactor accident in Windskey (UK) in 1957, the Trimal Island nuclear power plant (USA) in 1979, and the Chernobyl nuclear power plant in 1986 and the Japan nuclear power plant in 2012-2013.

In the aftermath of these catastrophes, some states have worked to stop the use of nuclear energy.

3. Hydropower, hydroelectric power plants are characterized by the recovery of energy resources without consumption, environmentally friendly type of energy, low cost, high capacity and integrated use of water resources for economic purposes. However, the construction of power plants is associated with the flooding of large areas of land, which is detrimental to nature.

Agriculture will not only lose fertile land spent on the construction of reservoirs, but will also suffer great damage in the sheep parts of rivers where hydropower plants have been built. Because in this case the spring flow of the river decreases. In low-moisture pastures, productivity decreases.

4. Alternative energy sources, non-traditional renewable energy sources Sunlight, sea urchins, internal temperature of the earth, organic waste are increasingly used in electricity. German and Japanese scientists have proposed the types of solar devices used in the national economy. They can be used to heat homes, provide electricity and many other purposes.

5. Geothermal energy, the use of geothermal water is much more convenient from the point of view of nature protection.

The earth's crust has rich sources of heat energy. According to approximate figures, 8$1017 \mathrm{k} \mathrm{J}$ of geothermal energy can be obtained from a layer up to a depth of $3 \mathrm{~km}$.

The first underground hot water power plant was built in Italy in the early twentieth century. It was later built in New Zealand, the United States and Japan. 
PEDAGOGY AND MODERN EDUCATION: TRADITION, EXPERIENCE AND INNOVATION - INTERNATIONAL CONFERENCE

Published: February 05, 2021| Pages: 16-18

Geothermal waters are very strongly mineralized. They are not easy to use directly. The potential of geothermal energy is much lower, i.e. the temperature of the water or steam coming out of the well is not high. This affects the efficiency of the use of such energy. At present, the temperature of the heat source must not be less than 150 for electricity generation. In this case it is sent directly to the turbines. The cost of energy obtained in this way will be much more expensive.

6. Solar energy, the amount of solar energy coming to the earth is about 20 times more than the amount of energy produced in the world. However, the density of solar current is low, so it is very difficult to accumulate this energy. As a result, energy becomes more expensive. A well-developed direction today is to convert solar energy into potential heat. It uses agricultural products in the construction of heating, hot water supply of houses. The conversion of sunlight into electrical energy is possible in powerful geostations located in orbits.

7. Wind energy is one of the alternative sources of electricity that only wind can generate enough energy without harming the environment.

8. Wave energy is environmentally friendly. The use of such energy provides the energy of sea water to heat houses in winter and coolness in summer.

\section{CONCLUSION}

The alternative sources of energy under consideration are of local importance and cannot radically change the fuel energy structure of the state. However, the use of environmentally friendly energy sources will increase in the future.

REFERENCES
1. SultonovR.S. Fundamentals of Ecology and Environmental Protection.-T. "Music", 2007.

2. Ergashev A.E., Sheraliev A.Sh, Suvonov X.A, Ergashev T.A. Ecology and nature protection. Tashkent "Fan". 2009.

3. X.V.Salimov Ecology. Textbook. Navoi2015.

4. Alibekov, L. A., Alibekova, S. L., Nazarov, I. K., \& Gudalov, M. R. (2012). About some regularities of geosystems' degradation in Central Asia. Oecologia Montana, 21(1), 42-44.

5. Mirkomil, G., Bakhtiyor, Z., \& Dilfuza, I. (2020). Predicting Changes In Landscapes Around The Aydar-Arnasay Lake System. The American Journal of Engineering and Technology, 2(10), 6-12.

6. Абдурашидовна, Қ. А. (2020). АЭВИД ФОНДИ ВА КОЛЛЕКЦИЯЛАРИДАГИ ЎЗБЕКИСТОННИНГ Х АСРИГА ОИД АШЁЛАР ВА УЛАРНИНГ ЎЗИГА ХОС ХУСУСИЯТЛАРИ. Маданият чоррахалари, 4(2).

7. Курбанова, А. А. (2015). К ВОПРОСУ О ПРЕДМЕТАХ, ОСВЕЩАЮЩИХ ДРЕВНЮЮ ИСТОРИЮ УЗБЕКИСТАНА, ХРАНЯЩИХСЯ НЫНЕ В МУЗЕЕ АНТРОПОЛОГИИ И ЭТНОГРАФИИ ИМ. ПЕТРА ВЕЛИКОГО (КУНСТКАМЕРА) РОССИЙСКОЙ ФЕДЕРАЦИИ. Фундаментальные и прикладные исследования в современном мире, (105), $42-46$.

8. Gudalov, M. R. (2011). Analysis of natural and anthropogenic processes in the Aydar hollow. Izvestiya of the Uzbekistan Geographical Society.

9. Nematov, O., Kushbakova, M., \& Ruzimurodova, Z. (2020). SOME OF THE WORK WITH UNORGANIZED YOUTH IN THE NEIGHBORHOOD. Студенческий вестник, (11-3), 82-85.

10. Nematovich, N. O., \& Yusupovna, K. M. (2020). THE IMPORTANCE OF MODERN METHODS AND TECHNOLOGIES IN LEARNING ENGLISH. Science and Education, 1(1). 


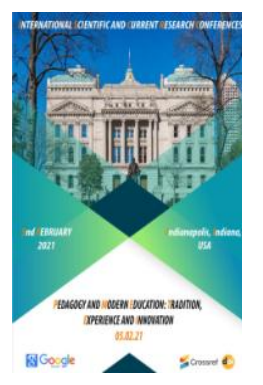

\section{The Behavioral Role Of Hupotalamic And Sensamotor Posts In Specification}

Khurshida Olimjonovna Pardaeva

Senior Lecturer Department of Biology Teaching Methods at JSPI, Uzbekistan

\section{ABSTRACT}

This article is devoted to the study of the sources that constitute the methodological foundations of the study of the hypothalamus and sensorimotor cortex behavior control in thirst.

\section{KEYWORDS}

Thirst, hypothalamus and sensorimotor cortex, behavior management, methodological basis, adaptation, neurobiology, physiological mechanism, bioenergetics of the organism.

\section{INTRODUCTION}

One of the most important and little-studied areas of modern neurobiology is the evolutionary approach to environmental laws, natural forms of adaptation, physiological mechanisms of functioning of a number of physiological systems in the process of adaptation to the habitat of animals with different phylogenetic lines and ecological specialization.

In this context, the study of the comparative role of the regulatory and motivational properties of a number of vertebrate organisms and the remarkable natural forms of their adaptation to adverse environmental conditions remains an urgent task.

E. Haeckel's fundamental views on the interconnected development of evolutionary organisms and the environment, I.P Pavlov's theory of conditioned reflexes, A.N Severtsov's theory of idioadaptive concept and aramorphosis, L.A. Orbeli's evolutionary and theoretical views, A.A .Ukhtomsky's 
dominance. The study of these areas, based on the theory of ecological and evolutionary views of D.A. Biryukov, A.I.Karamyan and A.S.Batuev on the difficult, crisis stages of development of brain integratum and activity in vertebrate phylogeny, now leads to extensive research.

\section{THE MAIN FINDINGS AND RESULTS}

Among them, one of the main tasks is to determine the variability of various functional systems in the process of oriented adaptation of the organism to extreme living conditions. However, despite the fact that the physiology of the functional interactions of the organism has been studied for several decades, not all the integrated systems of the brain have been fully studied. This is primarily due to the study of the role of the hypothalamic-cortical relationship in the organization of thirst and hunger motivation.

It is known that among the environmental factors, temperature is a factor that has a rapid impact on the body. [7; 27-29]. Quantitative criteria of temperature and their extreme fluctuations under natural conditions play a key role in supporting homeostatic processes.

Under the influence of temperature there is a significant increase in functional activity, changes in the electrical activity of organs, shifts in the regulation of metabolism and water-salt metabolism, its hormonal and neuropeptic status is determined in different physiological states of the organism. This problem has been studied regularly: Egorova N.A, Anoxin P.K, Askerov F.B, Gasanov G.G, Alekperova S.A, Nuritdinov E.N, Akhrorov D.T functional under the influence of temperature studied a significant increase in activity.

The results of these studies show that longterm and rapid exposure to high temperatures leads to the development of hyperthermia, accompanied by physiological, general- biological and physicochemical changes that cause serious disturbances in the functioning of functional systems.

Heat load leads to a significant loss of water and salts, electrolyte volume and blood composition, its elements in a certain form, the volume of loss of living mass and problems of changing the bioenergetics of the organism. It has been studied by scientists such as Gasanov G.G, Askerov F.B, Alekperova S.A,Vander T, Kerner Y, Romsos D.R, Gafurov B.G. $[1 ; 110-117 ; 2 ; 87 ; 3 ; 67-69]$

Thus, the urgency of the problem is beyond doubt and plays a very important fundamental role in relation to the activity of the organism in the extreme conditions of Central Asia. Smirnov V.M, Fudin N.A, Tkhoroevsky V.I. have studied the negative effects of high temperatures on human physical activity while Meerson F.Z, Pshennikova M.G, Sulimov A.V. scientifically study that the above-mentioned condition leads to the development of important functional disorders and stressful reactions for the organism. [4; 86-89; 5; 17-19]

Changes in the level of functional activity of some systems associated with the introduction of mechanisms serve to increase heat transfer and thermogenesis. In this regard, A.D. Slonim's [7; 44-48] have a special value. Based on the teachings of A.A Ukhtomsky, the scientist introduces individual adaptation to environmental factors into the development of systemic and structural homeostasis based on objective laws in the cells of the organism as the formation of a dominant functional system.

The concept of "motivation" began to play an important role in physiology, and the higher nervous activity of animals is now involved in the interpretation of the facts identified in the study. A. Batuev writes that, regardless of the motivating reasons for a specific goal-oriented behavior, some scientists combined behavioral analysis and were eventually 
forced to refer to concepts such as 'passion', 'desire, inclination', 'drive' which were close to the concept of 'motivation'.

Physiologist Kassil V.G. from the point of view, motivation, just like concepts that mean states such as appetite, hunger, satiety, thirst these are the mechanisms that form the basis of satisfying the biological needs of the organism. [3; 19-21]

According to the author, such an approach makes it possible to overcome the ambiguity that sometimes arises when using physiological terms. This view is consistent with I.P.Pavlov's views on basic passions, the "goal reflex" and A.A .Ukhtomsky's dominance, which determines the behavioral vector.

Thirst motivation is a typical example of the physiological dominance that occurs in the body in the absence of water and, accordingly, directs the state of search. The structures of the hypothalamus play a leading role in creating a state of subjective thirst. This problem was solved by Batuev A.S, Gafurov B.G, Batuev A.S, Li Yu.S, Lakomkin A.I. such as scientists have studied. [6;13-14]

In this case, osmoreceptors are located, activating effects are directed to other signaling devices of the brain, even to the cortex of the large hemispheres. Given the scattering and contradictions of data pertaining to the central mechanisms of thirst, we found it necessary to systematically study the mechanisms of participation of different nuclei of the hypothalamus in the formation of thirst motivation. The purpose of the study was to study the behavioral responses of cats and rats to meet the body's need for water.

It should be noted that using the objective electrophysiological method, it is possible to observe the characteristics of the lateral section of the hypothalamus and its associated cortical areas in response to the transmission of conditional signals of different importance in thirst conditions.

For these purposes, it was necessary to study the nature of how the electrical activity of these structures of the brain changes during the execution of a system of conditioned reflex runs associated with free state and saturation with different nutrients. The aim of this study was to investigate the role of the hypothalamus and cerebral sensorimotor cortex in the management of thirst. Based on this, the following specific tasks were identified:

1. Study of the biological activity of the hypothalamus and cerebral sensorimotor cortex in cats kept on a salty diet;

2. Study of basic nutrient conditioned reflex activity in rats kept on a saline diet after bilateral disruption of the posterior lateral areas of the hypothalamus;

3. To study the effect of hypothalamic dysfunction on dry and wet food selection in animals;

4. Study of the electrolyte content of blood, urine and blood proteins in the conditions of a salty diet;

5. Study of base-nutrient conditioned reflexes under high temperature conditions;

6. Study of the electrolyte content of blood, urine and blood proteins under high temperature conditions.

The scientific novelty of our study is that for the first time in animals (cats, rats) kept on a salty diet, a description of the bioelectrical activity of the posterior lateral nuclei of the hypothalamus and the sensorimotor cortex of the brain was identified. However, in a momentary bilateral disruption of the posterior lateral nuclei of the hypothalamus, conditioned-reflex activity is developed with difficulty, while absolutely positive right-sided conditioned reflexes are found to be absent altogether. Experiments have shown that conditioned-reflex runs and unconditional 
eating are present in a strictly defined order in a normal diet. Conditioned-reflex runs to unsalted food are easier to form than salty foods. On the unsalted food side, the rats ate such a salty grain in the first test that they had previously rejected it when they ran to the "salty" manger. This is confirmed by another fact: during a strong and prolonged thirst during a salty meal was observed not only a decrease in the dynamics of the right conditioned reflex, but also the cancellation of the differential braking to sound signals. All of the above confirms that the adequate analysis of pathogens that signal the nutritional properties of water-salt balance in the context of an increase in sodium chloride in the body and a shift towards water deficiency is ensured by the interaction of external taste and internal viscerochemical sensors. Thus, the emergence of thirst motivation in rats is accompanied by certain transformations in the viscerochemical field of the organism, which in turn changes the initial properties of salty food intake in the taste chemical sensitivity system.

The study also showed that the main indicator of sodium excess is an increase in its concentration. Control of the amount of sodium in the blood plasma, reduction of the percentage of erythrocytes by hematocrit, reduction of the amount of protein in the blood plasma, sodium and water retention in the body and other types of asymmetric distribution of ions are known by means of the hypothalamic-pituitary system. For this reason, the study of the concentration of sodium, potassium, and oxylions in the blood, as well as the increase in daily diuresis during a continuous salty diet in cats, is another goal of the study.

The study also found that the thirst motivation generated through a salty diet and partial water deprivation was accompanied by the formation of a stationary excitatory foci with dominant features in the lateral section of the hypothalamus. Chemical stimulation of it by direct injection of sodium chloride into the lateral hypothalamus creates a stationary excitatory foci with dominant properties. Activates behavioral acts appropriate to the state of thirst. Prolonged presence of animals in high temperature conditions requires the emergence of specific behavioral reactions of the organism. In this case, the adaptation of the animal organism to this effect takes place, and the stabilization of the new physiological background occurs.

\section{CONCLUSION}

Thus, summarizing the above, it can be concluded that the morpho-functional mechanisms of water and food reactions reflect a complex system of dominance of animal behavior, which is controlled by numerous structures of the central nervous system. The study of these issues is of great scientific and theoretical importance, as it deals with biologically interrelated behavioral reactions of human and animal organisms.

\section{REFERENCES}

1. 1.Gasanov G.G, Askerov F.B, Alekperova S.A. Dynamics of changes in the content of acetylcholineterase monoaminooxidase in some nuclei of the hypothalamus after different periods of cooking deprivation and on the background of the restoration of the cooking regime // Probl.fiziol. hypothalamus. L .: 1985, - $217 \mathrm{p}$.

2. 2.Kassil V.G. Motivation as a factor in the formation of behavior in ontogeny. $\mathrm{V} \mathrm{kn}$ : Physiology of behavior. - L .: Nauka, 1987. $-257$.

3. 3.Kassil V.G. Pishchevoe behavior in ontogeny. -L . Nauka, 1990. -218 p

4. 4.Nuritdinov E. N., Ivazov N.I. Spyachka and behavior. - Dushanbe; Donish. 1992. $197 \mathrm{p}$.

5. 5.Nuritdinov E. N. Neuropeptides and behavior. - Dushanbe .: Sino, 2002., 150 p. 
Published: February 05, 2021 | Pages: 19-23

6. 6.Nuritdinov E.N., Axrorov D.T, Neuropeptides and dnsntsefalnye mechanisms of regulation of behavior, hypobiosis and spyachki in various representatives of divergent lines of gorpedatorov. - Samarkand: SamGU, 2010. - $211 \mathrm{p}$.

7. 7.Slonim A.D. Heterothermia and fiziologicheskaya homeopa II Evolutionary aspects of hypobiosis and winter spyachki. M., Nauka, 1986. - 244 p.

8. Gudalov, M., \& Gozieva, M. (2020). Ways to develor modern ecoturism in the Zamin basin. International engineering journal for research \& development, 5 .

9. Gudalov, M., \& Zikirov, B. (2020). Metnods of studying the landscapes around the Aydar-Arnasay lake system. International engineering journal for research \& development, 5 .

10. Gudalov, M., \& Gozieva, M. (2020, December). Development Of Tourism In Zaamin National Nature Park By The Cluster Method. In INTERNATIONAL SCIENTIFIC AND CURRENT RESEARCH CONFERENCES (pp. 111-114).

11. Абдурашидовна, Қ. А. (2020). АЭВИД ФОНДИ ВА КОЛЛЕКЦИЯЛАРИДАГИ ЎЗБЕКИСТОННИНГ $Х$ АСРИГА ОИД АШЁЛАР ВА УЛАРНИНГ ЎЗИГА ХОС ХУСУСИЯТЛАРИ.

Маданият

чоррахалари, 4(2). 


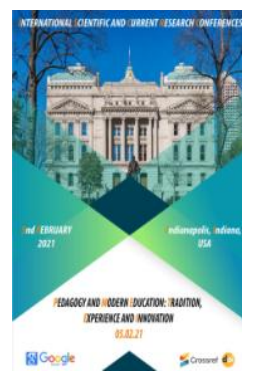

\section{Classify And Authorize A Pedagogical Program Of Global Citizenship Pedagogy In Foundational School Of Iran's Scholastic Structure}

M. Irfan Khan

Department Of Pedagogy University Of Tehran In Tehran, Iran

\section{ABSTRACT}

This Language Instructor Comprehension (LIC) study primarily explores language Instructors' beliefs and practices about a common Advised Second Language Procurement (ASLP) construct: Grammar Learning (GL). This study also aims to investigate to what extent Instructor beliefs and practices compromise with each other and cognitive and contextual factors behind their comprehension. The data were collected through interviews, observations, and stimulated recall with the Instructors. The findings after a cross-case analysis revealed that course book-based beliefs, experience-based beliefs, lack of theoretical knowledge and inclination for communicative activities influence what Instructors believe about GL. There are both congruent and incongruent relationships between beliefs and practices varying from one Instructor to another due to the effect of experiential knowledge, unconscious decisions, and some contextual factors. The findings can contribute to the integration of LIC into ASLP studies, and to LIC framework by exploring the effects of many variables on Instructors' decision-making processes.

\section{KEYWORDS}

Pedagogical program; Global Citizenship Pedagogy; Foundational School; Iran

\section{INTRODUCTION}

Globalization is on the ascent as proven by developing business sectors through a huge expansion in industrialized countries, products utilization, and the always widening utilization of innovation. Numerous teachers, lawmakers, business experts, and residents around the globe concur that essential, optional, and post-auxiliary understudies should be set up to live, work and flourish in a worldwide local area (Belt, 2016). 
In this way, worldwide citizenship schooling is one of the significant subjects that can be applied to a deep rooted learning viewpoint (UNESCO, 2014). Indeed, worldwide resident instruction is the procurement of information, perspectives, and abilities that support educated, basic, dynamic and dependable residents about neighborhood, public and particularly worldwide issues. According to Nodding's perspective, a worldwide resident is somebody who can live successfully anyplace on the planet through a worldwide lifestyle (Rapoport, 2009).

Likewise, numerous examinations have demonstrated that public citizenship training is a fundamental component of numerous proper instruction frameworks and numerous nations have now fused different parts of worldwide citizenship schooling into their pedagogical plans. In any case, worldwide citizenship instruction is a dubious, contentious and complex idea. In such manner, not just there are various changes on meanings of worldwide citizenship instruction, yet additionally some accept that this idea fairly doesn't appear to be genuine. Likewise, condemned the structure of cosmopolitan issues and worldwide citizenship. The underlying reaction to these reactions is that worldwide citizenship should be a base for the entire world on a homogeneous and all inclusive model of the western innovation; and to look for a general and widespread comprehension of a wide scope of explicit moral issues communicated that worldwide citizenship obligations and regard for social variety are predictable and fundamental certainties. Worldwide citizenship training is regularly connected with a comprehension of social variety, and attention to different societies and cooperation in multicultural trades are among the primary qualities of a worldwide resident. Likewise, worldwide citizenship is characterized as the acknowledgment of between worldwide availability and the normal relationship among individuals.
TECHNIQUE

In this blended strategies study, to investigate the construction of pedagogical program of worldwide citizenship training, the subjective technique was initially utilized; in the subsequent stage, to affirm the design in bigger example size and to improve the generalizability of the determined model, the quantitative stage was performed utilizing instructors' sentiments.

The subjective information was accumulated through close to home meetings with experienced employees (11 people), specialists (5 people) and educators (18 people) in the field of citizenship instruction. The reasonable model and topics were removed in the wake of dissecting the information. A poll was readied dependent on the information got from the subjective stage. The unwavering quality and legitimacy of the poll were affirmed and, in the quantitative stage, given to educators for approval and assessment of the model.

A semi-organized meeting was completed by certain specialists to discover what encounter they have about the issues with no direction and disposition. Likewise, to make the interviewees intellectually arranged and direct the meeting cycle, the system of the subject for the meeting was at that point planned and gave to interviewees.

The motivation behind the meeting was to choose proficient and experienced interviewees with the goal that the analyst shapes his/her hypothetical model. In this stage, information assortment was proceeded until the characterization of information and data arrived at immersion, and the hypothesis was correctly and totally clarified (Creswell, 2012). Since the point of this investigation was to investigate the elements of the pedagogical plan of worldwide citizenship training, the scientist attempted to pick the members who were pertinent to the 
exploration subject all together for viable and solid association in this undertaking. To build up the investigation hypothesis, purposive and snowball inspecting strategies were utilized to acquire a profound comprehension of the subject.

\section{DISCUSSION}

All in all, it ought to be noticed that the marvel of globalization is an inescapable cycle affecting numerous zones like training. Subsequently, neighborhood conventions and qualities can be advanced with reasonable activities especially by giving a model and planning a proper pedagogical program in this field, particularly in the grade school which is the time of the arrangement of students' scholarly and individual system, while safeguarding worldwide information and securing worldwide citizenship. The job of the instructor in verifiable learning is indispensable and significant. Since they can utilize the verifiable learning of the student through a definite Classify, and right and survey the certain discovering that is conflicting with the express pedagogical plan. Our outcomes are predictable with the aftereffects of Santos' (2004) research. Likewise, the part of the instructor in managing the mediating conditions and, obviously, with gave fitting settings, will prompt positive results in the program results like building up the segments of the information, ability, and demeanor. Aftereffects of Pugliese's exploration (2015) likewise affirm this assertion.

\section{CONCLUSION}

Worldwide citizenship training is one of the significant issues which needs exceptional consideration explicitly for underdeveloped nations because of the marvel of globalization. As we talked about in this investigation, it is extremely valuable to allude to the instructive arrangement of nations and their well-qualified's feelings to formalize this issue. Accordingly, since worldwide citizenship instruction is an instructive subject, schools, particularly foundational School, can be pioneers in this field. In such manner, it ought to be noticed that albeit the worldwide citizenship instruction should be possible outside of school, formal training gives better arrangements and it is more organized. This investigation gives a few useful rules in the pedagogical plan of worldwide citizenship training in grade schools. Initial, a model that is utilized as a calculated system for instructing worldwide residents in the rudimentary pedagogical program. This model has planned dependent on the information, comprehension, and experience of most of members in worldwide citizenship schooling request, which is a suitable measures for a more profound comprehension of the pedagogy program of worldwide citizenship instruction. Second, the part of authoritative factors particularly hierarchical help is an unequivocal job in policymaking and building up an pedagogical program which is very much tended to in this model. At last, it very well may be expressed that instruction should be viewed as a viable, comprehensive, and deep rooted responsibility. In our reality that innovation changes quickly, for students' learning, instruction should focus on the different learning possibilities and capacities of students to take an interest at neighborhood, public, and worldwide levels, instead of zeroing in on a specific social or political viewpoint.

\section{AFFIRMATIONS}

We might want to thank all the employees, specialists and educators in this examination for imparting their important insights. We additionally appreciate the mysterious commentators who invested their energy and assisted us with improving the original copy with their significant remarks. 
Published: February 05, 2021 | Pages: 24-27

\section{REFERENCES}

1. Bench, H., and Kranfelly, y. (2018). Assortments of second advancement: the cosmopolitan turn in social and political hypothesis and exploration. The British Journal of Sociology, 69(5), 609-643.

2. Geltom., H.K. A. (2019). Does worldwide citizenship training foresee distinguishing proof with all humankind?. Recovered from,

3. Earthy colored, L. j. (2018). Corroborative factor examination for applied exploration. New York, United States of America: Guilford Publications.

4. Caniyon, X. (2005). Cosmopolitan equity and social variety. World-wide Society, 18(5), 625-651.

5. Creswell, L. X. (2016). Instructive Research: Planning, Conducting, and Evaluating Quantitative 


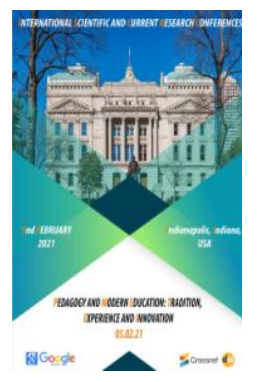

\section{Method For Separation Of Platinum From Platinum- Containing Waste Solutions}

Orifjon Naziralievich Usmankulov Head Of The Copper Metallurgy Department Of The Central Laboratory Of New Technologies Of Jsc "Almalyk Mmc", Uzbekistan

\section{ABSTRACT}

This article describes a new technology for the separation of platinum and palladium from solutions after gold electrolysis. As a result of the research, the presence of platinum metal in the solutions of the copper smelter of JSC "Almalyk MMC" was determined and work was carried out on its extraction. The concentration of platinum and palladium in the solution is low, so the method of forming an inelastic complex during their initial precipitation was used. This was followed by palladium and platinum refining steps involving several pyrometallurgical and hydrometallurgical processes. In the end, positive results were achieved and the developed new technology is applied to the production of these metals. [1]

\section{KEYWORDS}

Electrolyte, decantation, platinum, thiourea, precipitation, heating, complex compound.

\section{INTRODUCTION}

Worldwide, there is a shift towards clean energy, according to the Wall Street Journal, so investors have boosted demand for platinum, with metal prices now rising 14 percent. [2]

In recent years, the use of platinum has been expanding worldwide, especially in Uzbekistan. This is the main reason for the rise in the price of platinum. 
PEDAGOGY AND MODERN EDUCATION: TRADITION, EXPERIENCE AND INNOVATION - INTERNATIONAL CONFERENCE

Published: February 05, 2021 | Pages: 28-31

\section{Rising platinum prices in Uzbekistan}

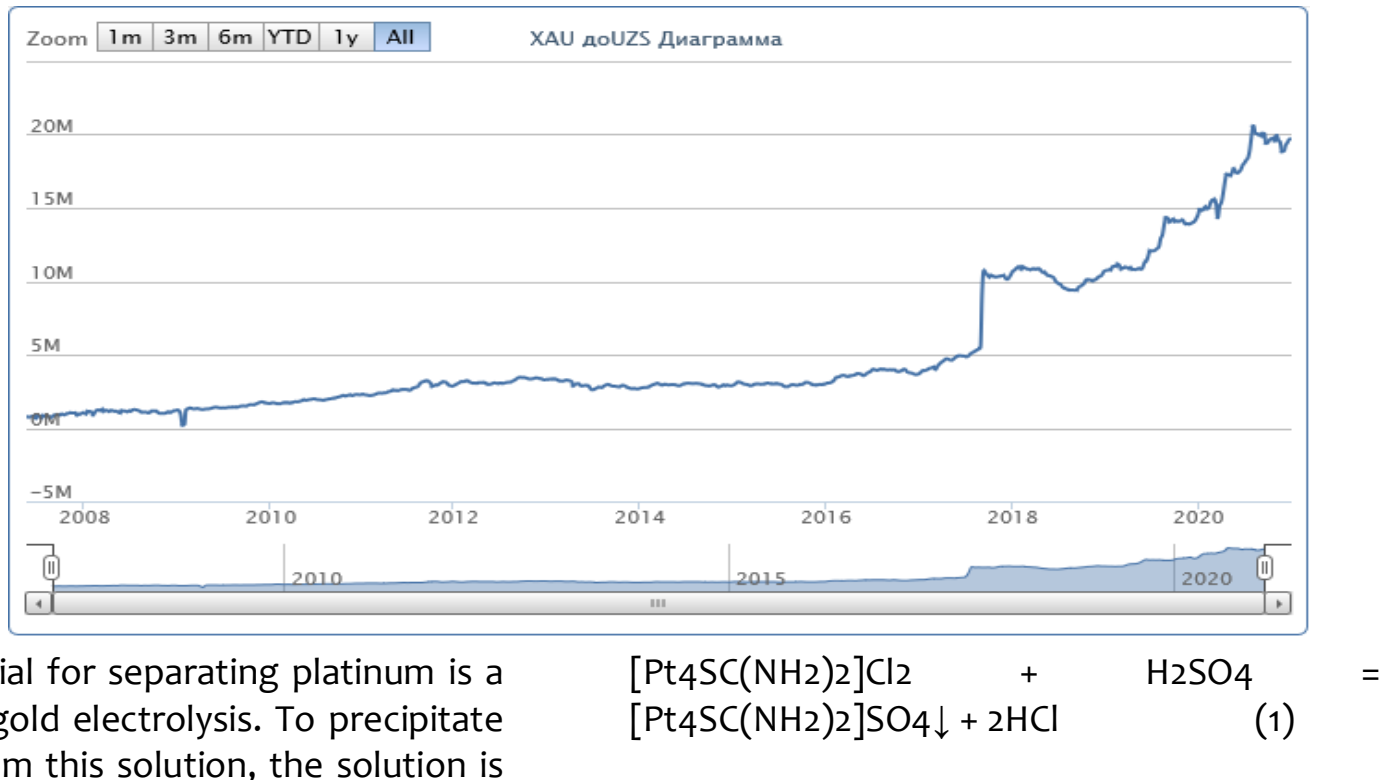

The raw material for separating platinum is a solution after gold electrolysis. To precipitate all the gold from this solution, the solution is treated with hydrazine, while the gold is reduced to a state of zero valence and precipitated. Platinum and palladium, on the other hand, are reduced from the 4-valent state to the 2-valent state, but do not sink. Then the solution is sent to the separation of platinum and palladium. Due to the low valence state of these metals in the solution, they do not precipitate under the influence of conventional precipitators. Therefore, additional measures were taken to precipitate platinum from the solution. Platinum and palladium solution is in the form of chloride $\mathrm{PtCl} 2$, the concentration of $\mathrm{PdCl} 2$ is on average $50-400 \mathrm{mg} / \mathrm{l}$.

Extraction of high purity platinum powder is carried out in the following sequence.

The initial solution is heated to $70^{\circ} \mathrm{C}$ and a thiourea solution is added to it according to the amount of platinum in the solution. For example, $1 \mathrm{~m} 3$ This forms a thiourea-soluble complex of platinum [Pt4SC $\left(\mathrm{NH}_{2}\right)$ 2] Sl2. For platinum precipitation, the solution is stirred well with $30 \%$ sulfuric acid while continuing to heat, allowing the platinum to settle completely for 40-50 minutes.
When the thiourea-insoluble complex of platinum $\left[\mathrm{Pt} 4 \mathrm{SC}\left(\mathrm{NH}_{2}\right)_{2}\right] \mathrm{SO}_{4}$ is completely precipitated, the precipitate is filtered and thoroughly washed with distilled water, and the resulting solution is directed to the separation of palladium.

The platinum-containing precipitate, washed from other water-soluble compounds and acid residues, is dried at $110-120^{\circ} \mathrm{C}$ for $1-1.5 \mathrm{~h}$. After drying, the precipitate is placed in special crucibles and baked in a muffle furnace at $1000^{\circ} \mathrm{C}$. The firing process is carried out in several stages, initially holding the temperature at $400^{\circ} \mathrm{C}$ for 30 minutes and at $500^{\circ} \mathrm{C}$ for 45 minutes, until the temperature rises to $1000^{\circ} \mathrm{C}$ and then for one hour at $100^{\circ}$ C. The burning process is based on the following reaction:

$\left[\mathrm{Pt} 4 \mathrm{SC}\left(\mathrm{NH}_{2}\right)_{2}\right] \mathrm{SO}_{4}+2 \mathrm{O}_{2} \rightarrow 4 \mathrm{Pt}+\mathrm{CO}_{2}+2 \mathrm{SO}_{2}$ $+\mathrm{N}_{2}+2 \mathrm{H}_{2} \mathrm{O}$

At the end of the process, platinum powder is obtained, which may contain small amounts of palladium and other non-ferrous metals. The insoluble property of platinum in nitric acid is used to purify the obtained platinum powder from other elements. A $20 \%$ solution of nitric 
acid is prepared and the platinum powder is thoroughly washed in this solution (S: $\mathrm{Q}$ ratio 4: 1) at $60^{\circ} \mathrm{C}$ for one hour. In this process, almost all of the palladium and other nonferrous metals are dissolved. The solution is separated from the platinum powder by filtration or decantation, the resulting wet powder is washed with bidistilled water and dried. At the same time, platinum powder with a purity of $86.9 \%$ and $99.90 \%$ purity will be produced.

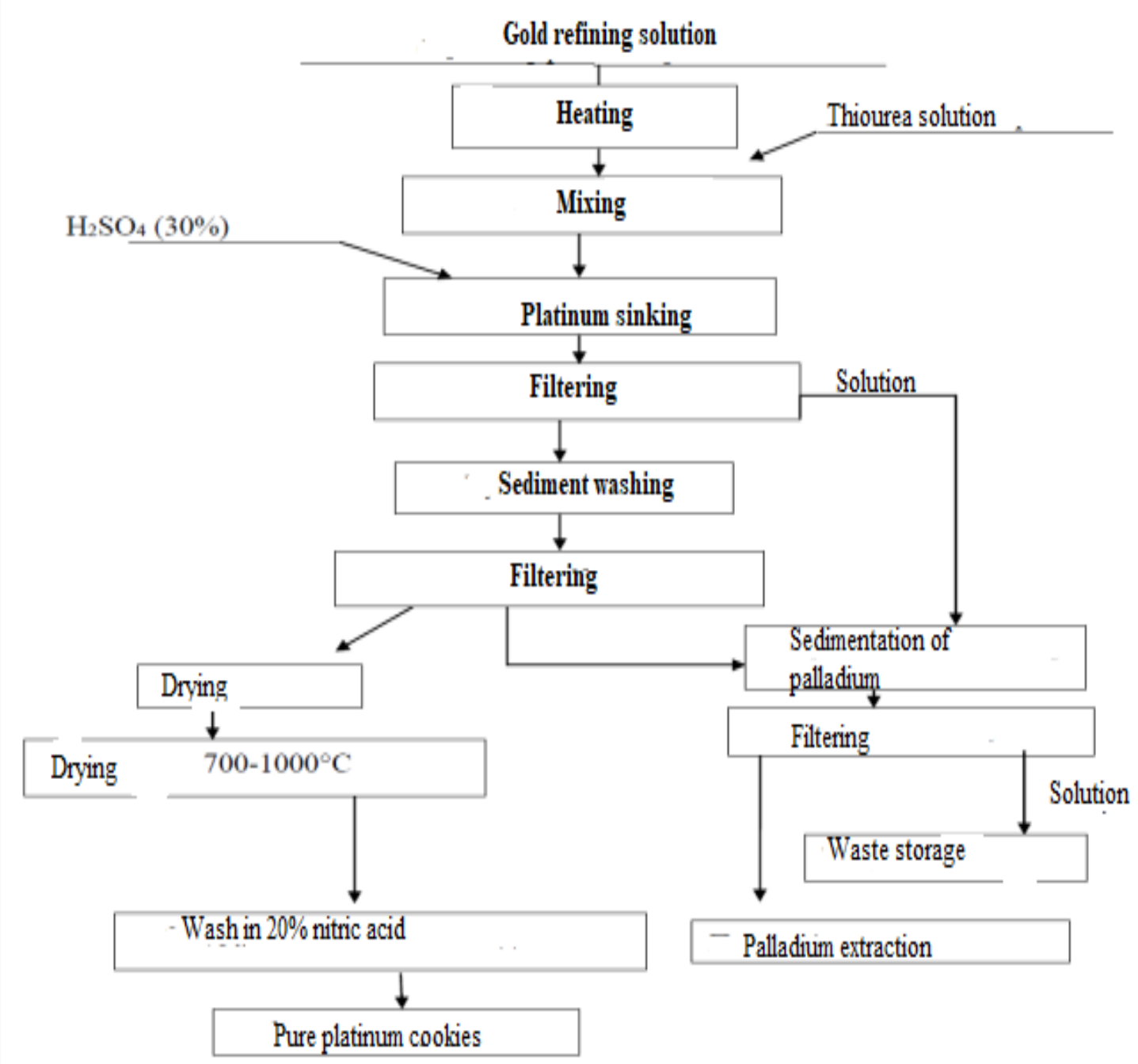

Figure 1. Scheme of separation of platinum powder from gold refining solutions

This technology is embodied:

1. The technology of obtaining refined platinum powder consists of simple, relatively easy processes and includes 16 operations.

2. Provides high efficiency (> 86\%) separation from low-platinum solutions as a result of its application. 
PEDAGOGY AND MODERN EDUCATION: TRADITION, EXPERIENCE

AND INNOVATION - INTERNATIONAL CONFERENCE

Published: February 05, 2021 | Pages: 28-31

3. The purity of platinum in the form of powder is higher than $99.90 \%$.

The application of this technology also serves to separate valuable components from waste solutions, as well as to neutralize and neutralize them.

\section{REFERENCES}

1. Metallurgy of noble metals, Book 2 Yu.A. Kotlyar, M.A. Meretukov, L.S. Strizhko. Publishing house "Ore and Metals", Moscow 2005 -Pp. 366,367 and 368

2. https://www.interfax.ru/world/739266

3. Method for extracting platinum from chloride solutions, Sidorenko Yu.A. Shulgin D.R. V.A. Nasonova Maltsev E.V. Bezprozvannykh I.V. RF patent 2175677. Publication date 10.11.2001.

4. Method for producing platinum metal powder, Antipov N.I. A. V. Tarasov RF patent2 136770 publication date: 09.10.1999. 


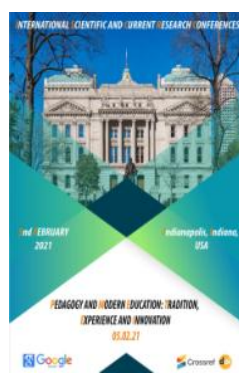

\title{
Interrelationship Between Life Quality And Vegetative Nervous System In Patients With Asthma
}

\author{
Muborak Saidobdullaevna Salaeva \\ Associate Professor Department Of Internal Diseases №2 Tashkent Medical Academy, \\ Uzbekistan \\ Nargiza Djurabaevna Salimova \\ Associate Professor Department Of Internal Diseases №2 Tashkent Medical Academy,, \\ Uzbekistan
}

\section{ABSTRACT}

The aim of this work is researching the interconnection of parameters of quality of life and the vegetative nervous system in patients with asthma.

Material and methods: Clinical and functional studies of 62 patients with asthma on the basis of Pulmonology Institute of TB and Pulmonologist Ministry of Health of Uzbekistan Republic were conducted. Quality of life was determined by the Seattle questionnaire comprising 29 questions that assess physical condition, emotional state, the state of professional competence and satisfaction with treatment.

State of the vegetative nervous system was assessed by Cardiointergraphic (CIG) on Bayes (1976). The obtained data were processed statistically using Student's t test.

Result: Patients with asthma often marked stress and disruption of adaptive-compensatory abilities of the body and reduced quality of life parameters. Patients with asthma defined relationship is more pronounced reduction in QL parameters in physical and emotional state of hypersympathicotonic and vagotonys. Reducing of QL parameters in patients with asthma is not established due of reducing these parameters on the state of the vegetative reactivity. The expansion of rehabilitation measures aimed at restoring the adaptive-compensatory abilities of the body, can help to restore and improve the quality of life of patients with asthma.

\section{KEYWORDS}

Bronchial asthma, vegetative nervous system, quality of life. 
Published: February 05, 2021 | Pages: 32--36

\section{INTRODUCTION}

Bronchial asthma (BA), is not only medical, social and economic, but also the general humanitarian problem (3).

Respiratory diseases occupy the top in prevalence in Uzbekistan. The indicator of illness over the past 5 years has increased by 2.5 times. The frequency of temporary disability and disability from COPD in the Republic increases annually. Mortality from this pathology is 1.5-2-times higher than the corresponding indicators in Russia (4). According to official statistics, in 2001 the number of patients in Uzbekistan with chronic nonspecific lung diseases was 3.5 times higher than the number of patients with diseases of cardiovascular system.

Clinician's interest is increased in study of the functional state of the vegetative nervous system (VNS) currently. VNS mediates its effect on the functional state of the bronchial tubes through the sympathetic and parasympathetic regulation mechanisms. Influences are transmitted via vagus, causing contraction of bronchial smooth muscle, through the pulmonary sympathetic plexus adrenergic effects, relaxing smooth muscle (2).

Assessment of quality of life (QL) of a person takes the major place in the clinical and sociomedical researches, assessment the degree of comfort within themselves and within their society. QL related to health, - a set of parameters describing the various aspects of human functioning: physical and psychological state, social relations, the functionality of the period of his illness $(1,8,9)$.

Found that in $A D$ is a significant decline in the quality of life of patients $(4,5,6,7)$. Interconnection between subjective feelings of the patient and objective parameters that characterize the vegetative nervous system has not been studied.

\section{Objectives}

The aim of this work is researching the interconnection of parameters of quality of life and the vegetative nervous system in patients with asthma.

\section{MATERIAL AND METHODS}

Clinical and functional studies of 62 patients with asthma on the basis of Pulmonology Institute of TB and Pulmonologist Ministry of Health of Uzbekistan Republic were conducted. Quality of life was determined by the Seattle questionnaire comprising 29 questions that assess physical condition, emotional state, the state of professional competence and satisfaction with treatment.

State of the vegetative nervous system was assessed by Cardiointergraphic ( $\mathrm{CIG}$ ) on Bayes (1976). The obtained data were processed statistically using Student's t test.

\section{RESULTS AND DISCUSSION}

According to the study the initial vegetative tonus that characterizes the adaptive ability of the organism to the disease, in patients with asthma noted that only 30\% remains adaptability, manifested Ayton (ET), at 20,9\% shows the state sympathic (ST), which determines the voltage adaptation possibilities, at 45,3\% - hypersympathicotonia (HST) and 4,8\% - vagotonia (VT), reflecting the failure of the state of adaptation options.

Comparing the state of autonomic tone with the original parameters QL of patients with asthma found that the stress and frustration 
PEDAGOGY AND MODERN EDUCATION: TRADITION, EXPERIENCE

AND INNOVATION - INTERNATIONAL CONFERENCE

Published: February 05, 2021 | Pages: 32--36

of adaptive capacity had significantly marked and emotional state (table 1).

reduction of QL parameters for the physical

Table 1

Specifications QL in patients with asthma with various conditions vegetative tonus (in basis points)

\begin{tabular}{|c|c|c|c|c|c|c|c|c|}
\hline \multirow[b]{2}{*}{ Pairmetres } & \multirow{2}{*}{$\begin{array}{c}\text { Ma } \\
\text { xpo } \\
\text { ssib } \\
\text { le }\end{array}$} & \multirow{2}{*}{$\begin{array}{c}E T \\
(n=18)\end{array}$} & \multirow{2}{*}{$\begin{array}{c}\text { ST } \\
(n=13)\end{array}$} & \multirow{2}{*}{$\begin{array}{c}\text { HST } \\
(\mathrm{n}=28)\end{array}$} & \multirow{2}{*}{$\begin{array}{c}V T \\
(n=3)\end{array}$} & \multicolumn{3}{|c|}{$\mathrm{P}$} \\
\hline & & & & & & $1-2$ & $1-3$ & 1-4 \\
\hline $\begin{array}{l}\text { Physical } \\
\text { condition }\end{array}$ & 5,2 & $3,09 \pm 0,20$ & $2,18 \pm 0,24$ & $2,38 \pm 0,09$ & $2,14 \pm 0,21$ & $<0,01$ & $<0,001$ & $<0,001$ \\
\hline $\begin{array}{l}\text { Emotional } \\
\text { condition }\end{array}$ & 7,0 & $4,02 \pm 0,37$ & $2,96 \pm 0,36$ & $2,72 \pm 0,20$ & $2,26 \pm 0,14$ & $<0,05$ & $<0,001$ & $<0,001$ \\
\hline Professional fitness & 7,0 & $4,09 \pm 0,32$ & $3,32 \pm 0,44$ & $3,09 \pm 0,19$ & $3,91 \pm 0,25$ & $>0,5$ & $<0,01$ & $>0,5$ \\
\hline $\begin{array}{l}\text { Complacen } \\
\text { cy by } \\
\text { treatment }\end{array}$ & 5,0 & $2,58 \pm 0,19$ & $2,69 \pm 0,12$ & $2,55 \pm 0,09$ & $2,5 \pm 0,10$ & $>0,5$ & $>0,5$ & $>0,5$ \\
\hline
\end{tabular}

The parameters of the physical condition of patients with asthma hypersympathicotonic were reduced - by $23 \%$, and in patients with asthma vagotony - by $31 \%$ compared to tonicity and respectively - 54\% and 59\% of the maximum possible points. Parameters of the emotional state of patients with asthma sympathicotonic reduced - by $26,4 \%$, from hypersympathicotonic - by $32,3 \%$ and vagotony - by $43,8 \%$, compared with patients with asthma and tonicity - by $57,7 \%, 61,1 \%$ and $67,7 \%$ of the maximum possible points. QL parameters fit and satisfaction with treatment in patients with asthma have been reduced to $55,8 \%$ and $50 \%$ respectively of the maximum possible values. However, without a significant decrease in these parameters depending on the initial vegetative tone.

The study of the compensatory capacity of the organism of patients with asthma, estimated by vegetative reactivity, showed that only $30.6 \%$ of patients with asthma recorded normal vegetative reactivity (NVR), reflecting preservation of compensatory abilities, in $54.8 \%$ of patients - hypersympathicotonic 
Published: February 05, 2021 | Pages: 32--36

vegetative reactivity (HSR) reflecting voltage compensation abilities and $14,6 \%$ asympathicotonic autonomic reactivity (ASVR) - failure mechanisms of compensation.
Comparing the form of the vegetative reactivity of patients with asthma with the parameters of quality of life was observed a significant reduction of the maximum possible values (table 2 ).

Table 2

\section{Specifications the patients QL with various conditions of asthma autonomic reactivity (in basis points)}

\begin{tabular}{|c|c|c|c|c|c|c|}
\hline Pairmetres & Max. & NVR (n=16) & HSR (n=34) & ASVR (n=7) & \multicolumn{2}{|c|}{ P } \\
\hline Physical & possible & & & & \\
condition & & & & & & \\
\hline Emotional & 7,0 & $2,96 \pm 0,32$ & $3,21 \pm 0,20$ & $3,08 \pm 0,45$ & $>0,5$ & $>0,5$ \\
condition & & & & & & \\
\hline Professional fitness & 7,0 & $3,22 \pm 0,26$ & $3,61 \pm 0,19$ & $3,53 \pm 0,42$ & $<0,2$ & $>0,5$ \\
\hline Complacency by & 5,0 & $2,47 \pm 0,09$ & $2,60 \pm 0,12$ & $2,77 \pm 0,17$ & $>0,5$ & $<0,2$ \\
treatment & & & & & & \\
\hline
\end{tabular}

Patients with asthma with normal vegetative reactivity parameter QL physical condition reduced - by $53,5 \%$ of the maximum possible, on the emotional - by $57,7 \%$, as a professional fitness - by $54 \%$, and treatment satisfaction - by $50,6 \%$ of the maximum possible score. Among patients with asthma and SSR ASVR quality of life parameters were also significantly reduced. However, we have not established communication with derating QL compensatory abilities of the body.

\section{CONCLUSIONS}

1. Patients with asthma often marked stress and disruption of adaptive- compensatory abilities of the body and reduced quality of life parameters. Patients with asthma defined relationship is more pronounced reduction in QL parameters in physical and emotional state of hypersympathicotonic and vagotonys.

2. Reducing of QL parameters in patients with asthma is not established due of reducing these parameters on the state of the vegetative reactivity

3. The expansion of rehabilitation measures aimed at restoring the adaptive-compensatory abilities of the body, can help to restore and improve 
PEDAGOGY AND MODERN EDUCATION: TRADITION, EXPERIENCE AND INNOVATION - INTERNATIONAL CONFERENCE

Published: February 05, 2021 | Pages: 32--36

the quality of life of patients with asthma.

\section{REFERENCES}

1. Chuchalin A.G, Belevsky A.S, Smolenov I.V etc. Is it possible to improve the quality of life in patients with asthma? (Results of a multicenter prospective study of the effectiveness of beclomethasone dipropionate, fluticasone propionate and salmeterol in patients with asthma). Pulmonology, 2004, № 2, p. 50-59.

2. Chuchalin A.G. (A member of the editorial board), Sienkiewicz N.Y. The quality of life of patients: the influence of bronchial asthma and allergic rhinitis. Ter. Archive, 1998, № 9, p. 5357.

3. Czerniak B.A, Trofymenko I.N, Belevsky A.M. Quality of life in patients with bronchial asthma and chronic obstructive pulmonary disease (EDITED Arabskoe A.G.Chuchalina.)-M, 2004, p.219-253.

4. EV Gubler, A.A. Genkin. The use of nonparametric statistics in biomedical research. - L, 1973.

5. Holgate S.T., Patridge M.R. Compliance in asthma / / Eur Respir. Rev. -1995. -Vol. 5. -P. 104-123.

6. Jones. P.W. Health status, quality of life and compliance / / Eur. Respir. Rev. -1998. -Vol. 8 (56). -P. 243-246.

7. Jones. P.W. Quality of life measurement In asthma / / Eur. Respir. J. -1995. -Vol. 8. -P. 885-887.

8. Kamalovna, N. U., \& Teacher, T. U. Creation and Use of Teaching Electronic Multimedia Books when Teaching Languages to Learners and Students in the Republic of Uzbekistan.

9. Thwaites R.M.A., Prise M.S. To reduce the burden of asthma: improving the quality of life of patients $/ 1$ Pulmonology. - 1998. - № 3. -P.19-23.
10. Ubaydullaev A.M, Functional methods for the study of bronchopulmonary apparate in pulmonology // Bulletin of the Association of Pulmonologists of Central Asia -T.-2000.- Vol. 4 (№ 1-4). p.79-95.

11. Ubaydullaev A.M, Ghafurov B.G, Kayumhodzhaev M.A. Psychovegetative disorders in patients with bronchial asthma. Ter. Archive, 1996, t.68, № 3, p. 44-47. 


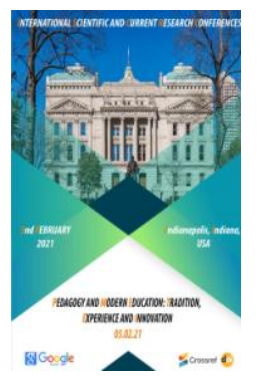

\title{
Xiva - Museum Under Open Sky!
}

\author{
Rustamjon Isoqov \\ 1st Year Master Student Of The Department Of "History And Ethnology Of The Peoples Of \\ Central Asia", Tashkent State University Of Oriental Studies Tashkent, Uzbekistan.
}

\section{ABSTRACT}

This thesis briefly highlights the city of Khiva and its role and importance in strengthening the Uzbek national identity. In addition, the city was informed about the attention paid by local and foreign organizations.

\section{KEYWORDS}

Khiva, national identity, tourism, Ichan Qala, Dishan Kala, Khorezm, World Heritage List

\section{INTRODUCTION}

The British Newspaper the Guardian has included Uzbekistan in the list of 40 recommended destinations for travelers in 2019. It is no exaggeration to say that this innovation is the result of recent reforms and innovations in the development of tourism potential in our country. In particular, direct flights from several European countries to the tourist centers of our country have been launched, and benefits for domestic tourism have been introduced.
Special government programs have also been developed to attract specialists to preserve cultural monuments and reveal their true historical significance and potential. In all of them, the main goal is to protect thousands of historical monuments in our country and further increase their tourist potential.

Our country is one of the leading countries in the world in terms of cultural heritage. There are more than a thousand cultural centers in Khorezm alone. It is known from history that the construction of cities and states in the Khorezm region dates back to the VIII-VII 
centuries BC. Thousands of years later, this place has not lost its historical value. Today, Khiva is one of the largest and most ancient cities in Khorezm, which is already included in the UNESCO World Heritage List and has been awarded the title of "Open-Air Museum". Legend has it that the city was founded in the 5 th century BC by Shem, the son of Noah. The city's popularity is due to the fact that it has been a trade route between East and West since its inception.

\section{THE MAIN FINDINGS AND RESULTS}

In the 16th century, the prestige of this city increased even more. This is because the city was designated as the capital by the Shaybani ruler Arab Muhammad Khan, and the name of the state in relation to this name is also called Khiva khanate. Khiva retained the status of the capital until 1920.

By the 19th century, the city had expanded into two parts, Ichan Qala Shakhristan (inner city) and Dishan Qala Rabot (outer city). Ichan Qala Shakhristan consists of a unique architectural structure, surrounded by a high cotton wall, the circumference of which is about 2200 meters, the height is 7-8 meters, and the thickness of the foundation is $5-6$ meters. Ichan Qala is rectangular in shape, 650 meters long and 400 meters wide, covering an area of 26 hectares, with four gates facing the four corners of the globe. The walls of the Ichan Fortress have been damaged and rebuilt several times over time.

Dishan Fortress is the outer part of the city, which was formed around Ichan Fortress in the mid-19th century. Dishan Qala was inhabited by poor artisans, artisans and small traders. The Dishan Fortress was surrounded by a high wall in 1842 and was built over a month by hashar, with the participation of more than 200,000 residents of the khanate. Agahi writes: "In the same year, 1268 AH (1842 $A D$ ), under the leadership of Muhammad Yaqub Mehtar and Otamurat, the construction of the Khiva wall began on Monday, the eighth of Rajab, and was completed in thirty days." The length of the wall surrounding Dishan Fortress was 6250 meters, and it had ten gates: Khazarasp (Sheep Gate), Pishkanik, Angariq, Shikhlar, Tozabog, Shohimardon, Doshyak, Gadoylar, Double Gate and Gandhimyon.

In addition to the settlements in Dishan Qala, the khan's summer residences had three gardens - Rofanik, Nurullabek and Nurullaboy. With the construction of Dishan Castle, the city was divided into two parts and the city area was expanded several dozen times. The age of the city was determined during the research conducted by the Academy of Sciences of Uzbekistan in 1984-1993. Archaeological excavations in Khiva show that the Ichan Qala area dates back to the 5th century BC. Artifacts (pottery and thick cotton walls) found in the lowest layer of the city testify to this. The cultural layer, pottery and a large amount of raw bricks found under the city walls confirm that the city is 2,500 years old. Today, these monuments are the only complex that has preserved its historical appearance. Castles and palaces, mosques and madrasas, mausoleums and minarets, caravanserais and baths, built over hundreds of years, have turned Ichan-Kala into a unique historical town.

Also important in Khiva are the ancient arch, the White Mosque, the Three Saints' Mausoleum, the Shergozikhan Mausoleum, the Allakulikhon Caravanserai, the Kutlug Murad Inaq Madrasa, the Muhammad Amin Inaq Madrasa, the 163-room Tashkhovli Palace built by Allahqulikhan, and others. 'are monuments of morphology, which show the mastery of the great masters of their profession in Khiva - painters, stonemasons, wood carvers. The flat towers of the buildings, the towering columns of the sky, the glazed bricks of the elegant towers, the majestic mausoleums with decorated green and blue domes, the unique beauty of the pattern with 
PEDAGOGY AND MODERN EDUCATION: TRADITION, EXPERIENCE AND INNOVATION - INTERNATIONAL CONFERENCE

Published: February 05, 2021 | Pages: 37-39

white decoration on a blue base come from the pages of oriental fairy tales. creates a wonderful urban impression.

In 1997, the 2500th anniversary of the city of Khiva was widely celebrated in our country. This was decided by UNESCO in 1995. The decision was made in order for the city to be recognized by the whole world.

\section{CONCLUSION}

In conclusion, it should be noted that the area of Ichan Castle is still inhabited. Interestingly, the locals decided to leave the houses where their ancestors lived somehow. Almost all tourists who come to our country do not return home without seeing the Khiva Ichan Fortress.

However, this does not mean that Khiva is using its full tourist potential. Cities full of architectural monuments around the world, such as Khiva, are visited by tens of times more tourists than Khiva today. So, we still have a lot of work to do. If we take full advantage of the tourist potential of our ancient cities, the number of tourists visiting our country will increase sharply, which will have a significant positive impact on the economic potential of our country.

\section{REFERENCES}

1. Askarov M.M. English-language Anthropology on the Uzbek Identity at the end of the XIX - the beginning of the $\mathrm{XX}$ centuries // Herald of Anthropology, 2020. № 1 (49). Pp. 239250. DOI: $10.33876 / 2311-0546 / 2020-49$ 1/239-258

2. Askarov M. Simbolurile naționale ale identității uzbece: 0 imagine de ansamblu // Revista de Etnologie şi Culturologie, 2020. Volume XXVII. Pp. 137-143. DOI: 10.5281/zenodo.3956788
3. Eshov B. Qadimgi O'rta Osiyo shakharlari tarikhi [History of ancient Central Asian cities]. Tashkent, 2006. Pp. 118-121.

4. National Encyclopedia of Uzbekistan. Tashkent, 2006. Vol. 9. Pp. 411-412.

5. Ogakhiy. Firdavs ul iqbal. Tashkent: Yangi Asr avlodi, 2010. Pp. 266-267. 


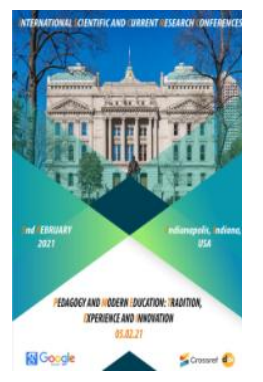

\title{
Optimal Technological Modes For Producing Bitumen- Rubber Compositions
}

\author{
Ilhom Akbarov \\ Namangan Engineering Construction Institute, Uzbekistan, Namangan \\ Murotbek Boydadayev \\ Namangan Engineering Construction Institute, Uzbekistan, Namangan \\ Madraximov Alloberdi Madraximov \\ Namangan Engineering Construction Institute, Uzbekistan, Namangan
}

\begin{abstract}
In this article highlights of determination of optimal technological modes for obtaining bituminous rubber compositions
\end{abstract}

\section{KEYWORDS}

Bitumen, technology, softening temperature, brittle temperature, elasticity.

\section{INTRODUCTION}

Elasticity, strength, water resistance, heat resistance and durability of roofing materials is an important and urgent task. When solving this problem, a special place is given to the use of modified bituminous materials that can provide elasticity, strength, water resistance, heat resistance and durability of roofing materials during the annual cycle. In this regard, there is a need to develop new compositions of polymer-bitumen materials using mineral ingredients for the production of effective, durable, roofing materials and technologies for their production for use in the construction of buildings and structures in dry and hot climates.

Analysis of the literature data and experience in the operation of roofing coverings made of traditional bituminous rolled materials have shown that in dry and hot climates, they quickly lose their original properties, prematurely collapse due to the influence of solar radiation and intensive thermal aging of the bitumen binder.

Significance of the System 
Let among the constrains (1) firstl, and among the constrains (2) firstd be the constrains of the first kind. If we In addition, one of the priorities of the developed economy of independent Uzbekistan is the localization of production and replacement of imported materials with local ones. This fully applies to roofing materials. Therefore, for the extreme climatic conditions of Uzbekistan, there is a need for scientific justification of the production of roofing bituminous materials of improved quality, with an increased service life.
In order to determine the optimal technological modes for obtaining bitumenpolymer compositions, the influence of the thermomechanical processing time, the temperature of the rubber powder destruction process, and its content on the degree of destruction of the rubber powder, as well as the softening temperature of the initial bitumen and their content were studied (figures 1.1-1.5).

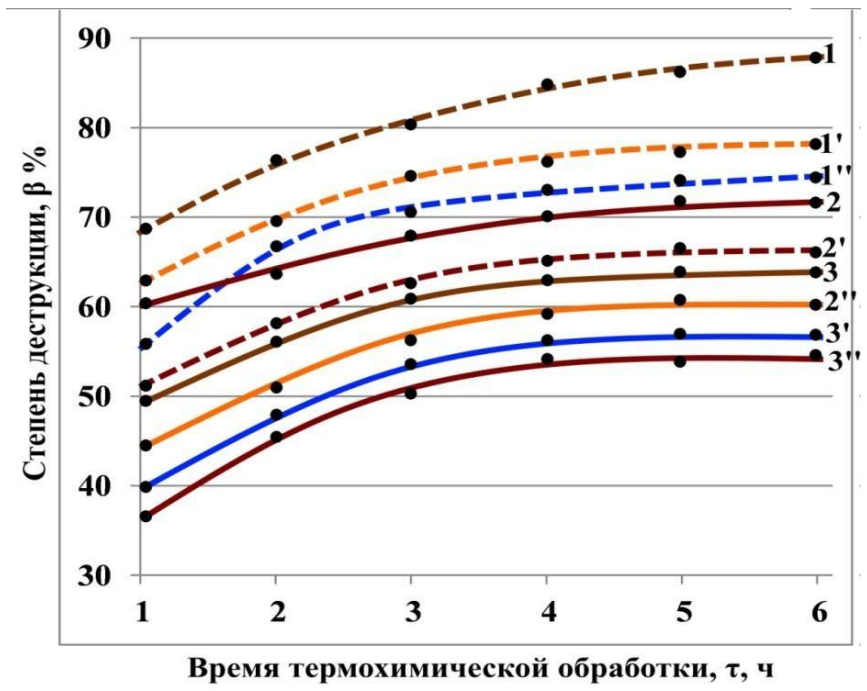

Figure 1.1. Dependence of the degree of destruction of rubber powder on the time of thermomechanical treatment in the pump-disperser of a bituminous-rubber composition with different contents of rubber powder (1, 2, 3-20 wt.h, $1^{\prime}, 2^{\prime}, 3^{\prime}-30$ wt.h, $1^{\prime \prime}, 2^{\prime \prime} n 3^{\prime \prime}-40$ wt.h and temperature of the thermomechanical treatment process $\left(1,1^{\prime}\right.$ and. $1^{\prime \prime}-230^{\circ} \mathrm{C} ; 2,2^{\prime}$ and $2^{\prime \prime}-210^{\circ} \mathrm{C} ; 3$, $3^{\prime}$ and $\left.3^{\prime \prime}-190^{\circ} \mathrm{C}\right)$.

\section{LITERATURE SURVEY}

In this article highlights of determination of optimal technological modes for obtaining bituminous rubber compositions Figure 1.1 shows the results of a study of the dependence of the degree of destruction of rubber powder on the time of thermomechanical processing in a pumpdisperser of a bituminous rubber composition, with different contents of rubber powder (20 wt. h; 30 wt.h; 40 wt.h) and the temperature of the processing process of thermomechanical processing of the composition(1900C, 2100C, 2300C).

From the curves in figure 1.1, it can be seen that in all cases, with increasing time of thermomechanical processing, the degree of destruction of rubber powder increases in all temperature modes of thermomechanical processing. The degree of destruction 
increases from $40-68$ to $55-88 \%$, respectively. It is also shown that the degree of destruction decreases with increasing content of rubber powder. Thus, with an increase in the content of rubber powder from 20 to $40 \mathrm{wt}$. h. the degree of destruction decreases from 88 to $70 \%$. The most degree of destruction of rubber powder is affected by the temperature of the heat treatment process. Thus, when the temperature increases from $1900 \mathrm{C}$ to $2300 \mathrm{C}$, the degree of destruction increases from 68 to $88 \%$, with a $20 \%$ content of rubber powder [1].

\section{METHODOLOGY}

Thus, the optimal mode of preparation of the modified bitumen-rubber composition is the temperature of thermomechanical processing of the composition-2200C, in the processing mode of 5 hours and the temperature of the initial bitumen is $380 \mathrm{C}$.

Figure 1.2 shows the results of softening of bitumen-rubber compositions, depending on the temperature of the initial bitumen, with different content and size of rubber powder particles.

With an increase in the content of rubber powder, for all the studied parameters, both at different contents and particle size, the softening temperature from the beginning is insignificant, and then, sharply increasing, tends to stabilize. In this regard, taking into account the technological and operational process, we selected the softening temperature of the initial bitumen in the range of 38-400C.

\section{EXPERIMENTAL RESULTS}

Based on the analysis, by us the optimum particle size of rubber powder were taken 0.6 $\mathrm{mm}$ and the content was in the range of $28-$ 30 wt.h.

Thus, the optimum compositions of hot bitumen of retinolacetate is the Temperature of original bitumen - 400C, content and particle size of rubber

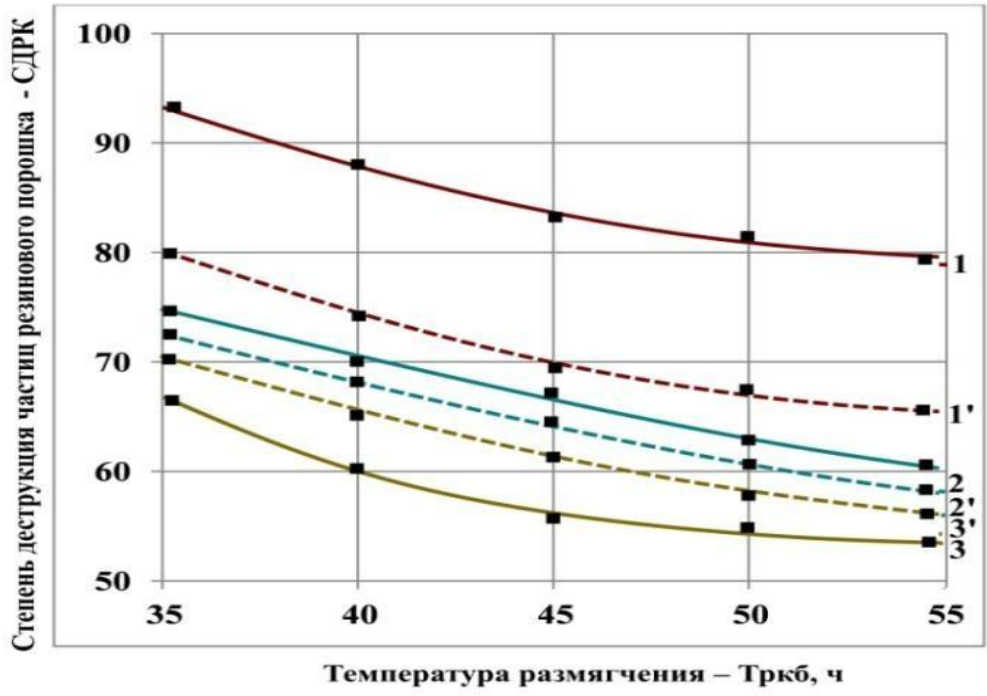

powder - 28 - 39 wt.h. and $0.6 \mathrm{~mm}$, respectively [2]. 
PEDAGOGY AND MODERN EDUCATION: TRADITION, EXPERIENCE AND INNOVATION - INTERNATIONAL CONFERENCE

Published: February 05, 2021 | Pages: 40-45

$$
\text { 1-0,3 mm; 2-0,6 mm; 3-0,9 mm; 1-20 wt.h.; 2-30 wt.h.; 3-40 wt.h. }
$$

Figure 1.2 Dependence of the degree of destruction of rubber powder on the softening temperature of the initial bitumen at different particle sizes and the content of rubber powder.

Figure 1.2 shows the results of studies of the dependence of the degree of destruction of rubber powder on the softening temperature of the initial bitumen at different particle sizes and the content of rubber powder. The curves of the figure show that the degree of degradation decreases with increasing filler content, both for different particle sizes and the content of rubber powder. As can be seen, high destruction of rubber powder in the bitumen-rubber composition is observed at a particle size of $0.3-0.6 \mathrm{~mm}$ and 20 wt.h.content.

Based on a comprehensive analysis of the above results, taking into account the technological process of the degree of destruction, the optimal softening temperature of the initial bitumen is $38-400 \mathrm{C}$, the content of the rubber powder of the bitumen-rubber composition is 28-30 wt.h. and the powder particle size is $0.3-0.6 \mathrm{~mm}$ [3].

Quantitative indicators of the degree of destruction of rubber chips in the bitumenrubber composition, depending on the duration of thermomechanical activation and the softening temperature of the initial bitumen, are also confirmed by the qualitative characteristics of the structure determined by IK spectroscopy. For this purpose, IK spectra of BRS of the composition 70\%-bitumen $+30 \%$ rubber powder were taken the initial bitumen had the initial softening temperature: 38,42 , 16,50 and $540 \mathrm{C}$, according to KISH.

\section{Conclusion and Future Work}

Thermo mechanical destruction of BPK was performed at the optimal temperature in the plastic pump for 6 hours. Every 2 hours, samples were taken and IK spectra were taken. The analysis showed that the most significant changes in the IR spectra of the studied BPK are observed in the absorption band (PP) with a frequency of $970 \mathrm{sm}-1$. This band is caused by out-of-plane deformation vibrations of the $\mathrm{CH}$-groups and 1,4-transdvion bond, which is characteristic of the structure of rubbers. Therefore, the relative content of double bonds can serve as a measure of the "dissolution" of rubber in bitumen[4].

It is known that the penetration and brittleness temperature of waterproofing and roofing materials to a certain extent characterize their elasticity. In order to justify the softening temperature of the initial bitumen in the bitumen-rubber composition for the roofing material cover composition, experimental studies were performed. Their results showed that the greatest elasticity of the bitumen-rubber composition is achieved when using bitumen with an initial temperature of 38 -and $420 \mathrm{C}$ (table 1). Therefore, in order to obtain bitumen-rubber cover roofing compositions for further research, bitumen-polymer compositions prepared on this initial bitumen are accepted. 
PEDAGOGY AND MODERN EDUCATION: TRADITION, EXPERIENCE

AND INNOVATION - INTERNATIONAL CONFERENCE

Published: February 05, 2021 | Pages: 40-45

Table 1.

Indicators of aeration and brittleness temperature of BRK.

\begin{tabular}{|c|c|c|c|}
\hline № & T r the source of bitumen & Pen, $\mathrm{x} 0,1 \mathrm{~mm}$ & T x p, ${ }^{0} \mathrm{C}$ \\
\hline 1 & 38 & 72 & 35 \\
\hline 2 & 42 & 64 & 30 \\
\hline 3 & 46 & 54 & 28 \\
\hline 4 & 50 & 43 & 26 \\
\hline 5 & 54 & 38 & 24 \\
\hline 6 & 62 & 33 & 22 \\
\hline
\end{tabular}

Based on the results obtained, the following conclusions can be drawn:

- the most significant factor is the softening temperature of the initial bitumen by KiSh. With increasing Трисх.битthe softening temperature of the filled bitumen composition also increases outside the study area. For technical reasons, the softening temperature of the initial bitumen should be limited by default and take $-380 \mathrm{c}$ :

- $\quad$ the second most important factor is the dispersion (diameter) of the rubber crumb. The obtained value of the optimal dispersion of the rubber crumb is $0.35 \mathrm{~mm}$;

the third most important factor, but no less important than the dispersion of the rubber crumb, is the degree of filling of the modified bitumen composition. As a result, the optimal value of the degree of filling of the composition is $28 \%$. Thus the optimal parameters of the modified bitumen composition should be considered $D=0,35$ $\mathrm{mm} . \mathrm{Cv}=28 \%$ итрисх.бит- $38^{\circ} \mathrm{C}$, the content of bitumen $-72 \%$.
Consequently, the conducted research confirmed the theoretical and practical prerequisites for the structure formation of a bituminous-rubber composition, which allows us to develop the optimal composition and technological mode for obtaining bituminouspolymer compositions with good physical, mechanical and operational characteristics.

The developed bitumen-polymer compositions can be used independently, as an elastic cover composition of roofing material, and for obtaining waterproofing and roofing materials.

\section{REFERENCES}

1. Negmatov S.S., Salimsakov Yu.A. and dr. «Issledovanie varochnyx i fizikokhimicheskix svoystv mestnyx bazaltovyx porod // Kompozitsionnye materialy, 2003. - № 2. -p. 44.

2. Ruzieva B.Yu., Negmatov S.S. and dr. Prospects for the use of basalt ingredients in the development of 
Published: February 05, 2021 | Pages: 40-45

composite materials. // Compositional materials, 2004.-№2.

3. Akbarov I.G., Negmatov S.S., Boydadaev M.B. Issledovanie osobennostey i fizikokhimicheskix svoystv nemodifitsirovannyx neftyanyx bitumnyx materialov // Universum: Texnicheskie nauki: elektron. nauchn. jurn. 2020. № 2 (71). URL: http://7universum.com/ru/tech/archive/ite $\mathrm{m} / 8809$.

4. Kholmurodova D.K., Negmatov. S.S., Boydadaev M.B. Esearch influence of humidity of resined screw-polymer weight on parameters of physical and mechanical properties of composite wood and plastic plate materials. International Journal of Advanced Research in Science, Engineering and Technology, Vol.6, Issue 8. 


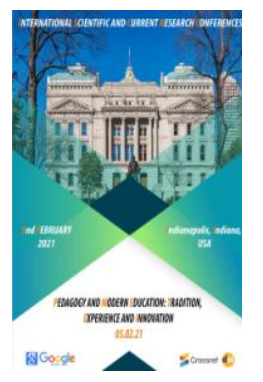

\section{About The Decoration Of Manuscript Books Of The Timurid Period}

Otabek R. JURABOEV

As. Prof. Dr., Deputy Director For Scientific Affairs Of The Alisher Navoi State Museum Of Literature Academy Of Sciences Of The Republic Of Uzbekistan

\section{ABSTRACT}

In the cultural aura of the XV century, the Timurid princes, who were the rulers of that time, occupied a place in a number of historical and literary sources of both literary figures and literary personalities. An artistic manuscript in the epoch of Timurides, as well as the other genres of that period, developed on the basis of creative assimilation of the best traditions of masters who had worked in the previous centuries. It is emphasized that this manuscript is a kind of a rare example of calligraphy and artistic design of a Timurid book.

\section{KEYWORDS}

Timurides, Alisher Navoi, divan, kitabat (book compilation), text, calligraphy.

\section{INTRODUCTION}

The category of artistic manuscripts in the epoch of Timurides (1370-1507) includes not only manuscripts decorated with miniatures, but also (and these are most numerous) maᄀnuscripts created only by calligraphers and designed by ornamentalists.

An artistic manuscript in the epoch of Timurides, as well as the other genres of that period, developed on the basis of creative assimilation of the best traditions of masters who had worked in the previous centuries. There were certainly numerous artistically designed and illustranted records of «Shakhname» by Firdausi, «Jam-at-tava- rikh» by Rashid-ad-din, «Khamsa» by Nizami as well as other unique records recopied in the XIIIXIV centuries under the rule of mongols, that were kept in public and private libraries of ancient Samarkand, Herat, Bukhara, Tebriz 
and Shiraz of the XIV and XV centuries. They could not but exert their influence on the further develop mment and formation of the new style in designing maᄀnuscripts in the age of Timurides. In the existing scientific literature dealing with artis 7 tic manuscripts the main subject of research is an oriental miniature. that took interest in oriental artistic manuscripts, dealt rhainly with the study of miniature painting as an independant genre, thus isolating it from the whole complex of artistic manuscripts.

Historical documents prove that valuable artistic maาnuscripts were indeed created at the orders of well-todo people and owners of court libraries: Shakhrukh, Ulugbek, Baisunkur, Sultan Khusein; and those were the people that acquired them for great sums of money. But the client could never predetermine the artistic solution of the design or its aesthetical norms, etc. The client could only appreciate the artistic merits of the finished work and re $\neg$ ward the artist according to his deserts.

\section{THE MAIN FINDINGS AND RESULTS}

The idea of designing manuscripts had originated and was forming in the workshops of artists in close creative contact with masters of all other genres in the art of book publishing. The craftsmanship of calligraphers, gilders, ornamentalists, miniature-painters and book-binders of the age of Timurides and the skilful synthesis of their art created unsurpassed samples of artistic manuscripts which the whole world admires up to the present time.

Illustrating by means of miniatures was common prac $\neg$ tice with fiction and historical works. It is no coincidence that the artistically designed and illustrated unique mannuscripts that are riow kept in all the large manuscript funds of the world mainly consist of records of Alisher Navoi and others. In contrast to miniatu $\neg$ res, whose sphere of use was rather limited, the use of ornaments knew no limits. Beginning with Koran, orna $\neg$ ments were used in all types of theological and secular literature.

Peculiarities of genre and the number of writings in $c$ cluded into the manuscript to be stipulated not only the size of the manuscript, but also the character of its artis 7 tic design. The handwriting (large, medium or small), placing the text in two or four columns, the quantity and type of frontispieces, headpieces at the beginning of every new work or chapter, the design of the margins, the theme, subject and quantity of miniatures and even the character of book-binding was decided by a group of artists and masters who worked at the creation of every single artis $\neg$ tic manuscript.

The harmonious combination of the creation of all the $\neg$ se masters which finally resulted in a single artistic synathesis answering the aesthetic demands of the age of Ti-mmurides was the constant care of every creator of artistic manuscripts. The development of the art of artistic manuscript and calligraphy as well as of the other spheres of life in the age of Timurides reached its culmination mainly in the second half of the XV century, when such people as Ali-sher Navoi, Kamal-ad-din Bekhzad, Sultan ali Meshkhedi, Mirik Nakkosh, Mavlyano Yari and others stood at the head of court «Kitobkhana» (library) in Herat. The great protector of science, literature and arts was Alisher Navoi.

In the XV century, in the age of Timurides, there existed Samarkand, Tebriz and Shiraz schools in the art of artistic manuscripts, and among these Herat school distinguished itself by realistic trends, by the variety of genres and by extreme skilfulness of its masters.

In S.Peterburg, in State Public Library named after Saltikov-Schedrin, there is a manuscript of an early divan (a collection of verses) by Alisher Navoi which was re-co $p$ pied in the year 
of 870/1465-1466 in Herat by the famous king of calligraphers Sultan Ali Meshkhedi (Dorn, 564). This manuscript is the earliest record of Navoi's writing and the very first manuscript by Sultan Ali Meshkhedi known to the scientific world. According to the tradition that existed at that time the names of gilders and ornamentalists, with few exeptions, were never mentioned. One shall not find the name of the author of ornaments in this manuscript too. There is every indication that this manuscript was created in the workshops of the court library of Baisankur Mirza, which are known to continue their activities both under Abul Kasim Mirza Babur and Abu Said. As a result of research carried out on the text we could ascertain that the above said manuscript belonged to the private library of Alisher Navoi.

The originality of the ornamental composition of the frontispiece and particularly of the painting and colouring indicates the appearance of a new style in the art of bookpublishing in Herat of the XV century. Also important is the fact that the above mentioned manuscript indicates the beginning of creative contacts between two great artistic geniuses of Herat - Alisher Navoi and Sultan Ali Meshkhedi, who then co-operated for nearly 40 years and maintained good friendly contacts. In the second half of the XV century calligraphy and the art of bookpublishing flourished unprecedentedly in the court library of Sultan Khusein.

\section{CONCLUSION}

The king of the calligraphers Sultan Ali Meshkhedi, the founder of Herat school of miniature painting Kamal-ad-din Bekhzad and the famous master of ornamenting books «nakkosh» (ornamentalist) of mavlyano Yari were great teachers of hundreds of masters who were creating masterpieces in the art of artistic manuscripts. Every artis $\neg$ tic manuscript taken separately was in itself a unique work of art. Thus, Tashkent manuscript «Diwan»
Alisher Navoi, even though it has no miniatures in it, can certainly be treated as one of the greatest masterpieces of Timuride. Artistic manus $า$ cripts, which are classic samples of the new original style of Herat school in the second half of XV century. The splendid ornament, rich colours and unique proportions in combining all the elements of the two above mentioned manuscripts are primarily stipulated by the high intellec 7 tual development and aesthetic demands of the age of Tiᄀmurides in the XV century.

\section{REFERENCE}

1. Juraboev, O.R. (2020) Kitabet Sanatının Bir Örneği Olarak Ali Şir Nevayi'nin "Bedayiü'l-Bidaye" Divanının Taşkent Nüshası. TRK International Journal of Humanities and Art. 2020, 1 (1), 13-27 p.

2. Sulaymon, Hamid (1969). The problems of studying artistic manuscripts and the art of calligraphy of the age of Timurides, Tashkent.

3. Sulaymon, Hamid (1968). Alisher Navoi. Ilk Devon. Faksimil nashr. Fan, Toshkent.

4. Hakimov, M. (1983). Navoiy asarlari qo'lyozmalarining tavsifi. Fan, Toshkent. 


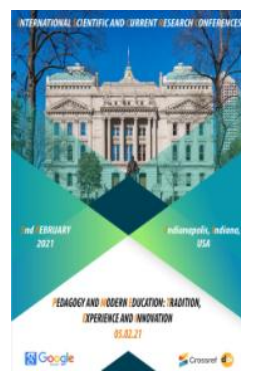

\title{
Periphrases Used Instead Of Medicinal Plants
}

\author{
Aziza Bakhriddinovna Kobilova \\ Lecturer Department of English Linguistics Researcher of Bukhara State University, \\ Uzbekistan
}

\section{ABSTRACT}

This article is devoted to the analysis of periphrases used instead of medicinal plants. The article analyzes the English periphrases used instead of medicinal plants and herbs.

\section{KEYWORDS}

Periphrasis, medicinal plants, language, linguistics, English language, description, medical linguistics, medical periphrasis, journalism.

\section{INTRODUCTION}

It is no secret that beautiful, attractive, significant, pleasant speech has always attracted humanity at all times and in all languages of the world, and such speakers were appreciated by people as preachers, orators, orators. In today's world, all professionals must be able to make their speeches effective and audible if they want to be successful in their field. In such cases, some language tools can help. One of these assistants is periphrases. First of all, what are retellings, where and when are they used?
In fiction, journalism, and many other fields, the repetition of words in the style of speech causes the appearance of paraphrases in our language, as a result of which the listener becomes bored. Periphrases are readily available in our language's vocabulary, so we classify them as regular expressions. In other words, periphrasis is the middle name of a word, or another name to prevent reuse [4, 215]. 
PEDAGOGY AND MODERN EDUCATION: TRADITION, EXPERIENCE AND INNOVATION - INTERNATIONAL CONFERENCE

Published: February 05, 2021| Pages: 49-52

\section{THE MAIN FINDINGS AND RESULTS}

The most important quality, feature, feature of the concept described in the paraphrase for the same text and situation is given priority. The main function of periphrases is to increase the expressiveness of the text, the effectiveness of the narration, therefore they are mainly found in the language of artistic, journalistic, and oral speech, and in scientific speech, they are devoid of imagery and are used as a term. The conversation is often confused with synonyms due to its frequent use in speech.

"Periphrasis" in Greek means "a detailed, broad explanation of a concise speech, the expression of a word in another word, a change in words to explain one word" $[1,553]$. This means replacing a word with a broader expression, or a broader expression of a concept using other concepts [2, 246]. In other words, this is the name of a word with a different composition, which is artistically colored. The use of white gold compositions exactly matches the periphrasis phenomenon.

Periphrasis is widely used not only in journalism but also in all other areas. At the same time, instead of plants, different periphrases are used to avoid repetition in articles or oral speech.

Pulmonaria officinalis is a beneficial herb found in herbs, peripheralized as follows: "Pulmonaria officinalis, common names lungwort, common lungwort, Mary's tears or Our Lady's milk drops, is a herbaceous rhizomatous evergreen perennial plant of the genus Pulmonaria, belonging to the family Boraginaceae" [See: www.wikipedia.org]. That is, Pulmonaria officinalis is popularly called "Mary's tears" or "Our Lady's milk drops".

Analyzing the following example, the plant turmeric is used with the periphrasis "healing spice": "Turmeric itself has also been known to be a "healing spice" and has been used to help many ailments" [See: www.nutritionstripped.com].

In English, chamomile is used as a peripheral word for herbal aspirin: "Described as "herbal aspirin", chamomile is one of the leading herbal remedies worldwide" [See: www.healthybutsmart.com]. Aspirin is medicine for headaches and various pains.

Because chamomile has the same medicinal properties, it is called natural aspirin: "How strong is the evidence base behind "nature's aspirin"?" [See: www.healthybutsmart.com].

Rosemary is described in the encyclopedia as follows: "Known as "herb of remembrance", rosemary also has long been tied to legends and traditions." [See: www.newworldencyclopedia.org/entry/Rose mary]. Since ancient times, this aromatic herb has had memory-enhancing properties. Perhaps that is why rosemary has become a symbol of fidelity and, in memory, in literature and folklore. Another source compares it not only with a symbol of memory but also with a symbol of friendship and love: Rosemary is traditionally known as the herb of remembrance and friendship. Also known as Mary's mantle and compass weed, rosemary is a lovely, sweet-scented, shrubby perennial in Mediterranean countries that can be grown as an annual in Northern climates or as an indoor potted plant [See: www.gardenmanage.com].

In the following example, a plant "cat's ear" is described as follows: "Dandelions are so similar to cat's ears (Hypochoeris) that cat's ears are also known as "false dandelions" [See: www.ricomeccanica.com]. Since the plant resembles a dandelion, it is called "false dandelion".

Oregano is peripheralized as the "joy of the mountain": "With a name derived from the Greek for "joy of the mountain" [See: 
www.newworldencyclopedia.org/entry/Orega no].

Spinach is widely used in all countries. Its benefits are enormous, especially because it strengthens the immune system. The English encyclopedia describes it like this: "The myth about spinach and its high iron content may have first been propagated by Dr. E. von Wolf in 1870 because a misplaced decimal point in his publication led to an iron-content figure that was ten times too high. In 1937, German chemists reinvestigated this "miracle vegetable" and corrected the mistake" [See:https://www.plantgrower.org/spinach.ht $\mathrm{ml}]$

Another wonderful plant is the aloe vera flower. In ancient Egypt, he was paralyzed as "a plant of immortality". We can learn this from the text of the following article: "2000 years ago, the Greek scientists regarded Aloe vera as "the universal panacea". The Egyptians called Aloe "the plant of immortality". Today, the Aloe Vera plant has been used for various purposes in dermatology" [9, 164]. This periphrasis is widely used, and we can find it also in other sources. Or another example: "According to a study published in the Indian Journal of Dermatology, in ancient Egypt, they called Aloe vera that "plant of immortality" [See: www.medicalnewstoday.com]. Another source, Nine Health Benefits and Medicinal Uses of Aloe Vera, explains that this flower is called a "wonder plant": "Aloe Vera, sometimes described as a "wonder plant", is a short-stemmed shrub. Aloe is a genus that contains more than 500 species of flowering succulent plants [See: https://www.medicalnewstoday.com/articles/2 65800].

It is no secret that coca basil is considered a useful and healing agent in all folk medicine. This was explained by British researchers in their articles with various peripheries. For example, in the encyclopedia, it is designated as "royal herb": "Basil has a long history of use, being known as the "royal herb" in ancient Greece, and employed in various cultures not only for culinary but also medicinal and religious use" [See: https://www.newworldencyclopedia.org/entry /Basil]. In another source, he is called the "king of herbs": "It is also called the "king of herbs" and the "royal herb". The name "basil" comes

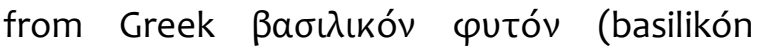
phutón), "royal/kingly plant" [See: www.evergetikon.gr].

Throughout our lives, we encounter many other periphrases representing plants and herbs. Such figurative expressions help to enrich our vocabulary and prevent the repetition of our speech.

\section{CONCLUSION}

In conclusion, paraphrases, which are part of linguistics, are one of the most common occurrences in our life. Beautiful speech, attractive speakers - from writers to our family members, all people, from journalism to medicine, even in oral speech, that is, in all areas and our daily life, such expressions are widely used. We use it sometimes voluntarily and sometimes involuntarily in our speech and create such words during a conversation. It would be a mistake to assert that not only linguists but everyone can be the author of a new paraphrasis.

\section{REFERENCES}

1. Alen P. The Oxford Illustrated English Dictionary. M.: Astrel, 2003. 553p.

2. "Annals of Nutrition \& Metabolism" , 26 Nov 2012, 61(3) 246-253p

3. Pardaeva, K. O., \& Sobirova, Z. O. (2021). Morpho-Functional Organization of Hypothalamus. The American Journal of Applied sciences, 3(01), 5-8.

4. Kobilova A.B. Features of the use of the periphrases of the Uzbek and 
English languages in journalistic texts. International Journal of Psychological Rehabilitation, Vol.24, Issue 07, 2020. Page: 8162-8168. https://www.psychosocial.com/article/ PR270794/18979/

5. Salakhova, E., Shamsitdinova, M., \& Shakhakimova, M. (2020). THE IMPACT OF INFORMATION TECHNOLOGIES ON DISTANCE EDUCATION DURING PANDEMIC IN THE REPUBLIC OF UZBEKISTAN. PalArch's Journal of Archaeology of Egypt/Egyptology, 17(6), 8962-8967.

6. Kobilova A.B. Periphrasis - as a stylistic device. Proceedings of Global Technovation 2nd International Multidisciplinary Scientific Conference. Hosted from London, U.K., December, 28th 2020. - Page: 215-216. https://conferencepublication.com 


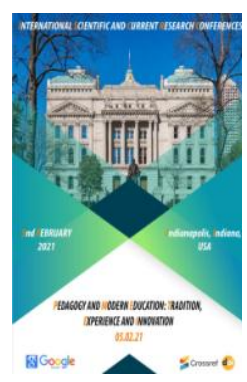

\section{Organization Of Tourism Services In Uzbekistan Based On The Combination Of National Styles And Modern Innovations}

B. F. Botirov

Associate Professor Department Of School Management, Jizzakh State Pedagogical Institute,

J. Usmonov

Senior Lecturer Department Of School Management, Jizzakh State Pedagogical Institute,

\section{R. I. Ablyakimova}

Lecturer Department Of School Management, Jizzakh State Pedagogical Institute,

\section{ABSTRACT}

The article is devoted to the dynamic development of innovative activities in the current tourism industry in Uzbekistan and the study of related infrastructure in terms of innovation, as well as practical recommendations for the scientific development of opportunities for innovative development of road tourism and tourism infrastructure in our country.

Young tourists also have the opportunity to get acquainted with rural life, nature and traditions through the organization of "Tourist Houses".

\section{KEYWORDS}

Innovation, tourism, innovative projects, car, tourism, pilgrimage tourism, gastronomic tourism.

\section{INTRODUCTION}

Currently, the concept of "Innovation" is widely used in all industries. The word innovation is an English word - 'innovative' means to introduce innovation, i.e. it is defined as changing the internal structure of a system. Innovation is an important part of practice and theory, a system of action of social actors aimed at improving the quality of socio-cultural objects. Innovations are up-to- date, important, new approaches formed in a system. They are born on the basis of initiatives and innovations and are promising for the development of economic activity. It also has a positive impact on the development of the economic system as a whole. Innovation is the end result of a technology, form, or method in a particular field of activity or production, a new approach to solving a 
PEDAGOGY AND MODERN EDUCATION: TRADITION, EXPERIENCE AND INNOVATION - INTERNATIONAL CONFERENCE

Published: February 05, 2021 | Pages: 53-57

problem, or the application of a new technological process that is known to lead to greater success than ever before.

Innovation projects - the main purpose of such projects is the development and application of new technologies, know-how and other innovations that ensure the development of enterprises.

The Main Findings and Results

This article is devoted to the dynamic development of innovative activities in the tourism industry of Uzbekistan and the study of related infrastructure in terms of innovation, as well as practical recommendations for the scientific development of tourism services and tourism infrastructure in our country.

Uzbekistan differs from many countries in the world in terms of its potential in the field of international tourism. When considering the tourist potential of the country, first of all, historical cities such as Tashkent, Samarkand, Bukhara, Khiva and Kokand, which are rich in ancient cultural and architectural monuments, have a special place.

In addition, the natural and geographical location of Uzbekistan has a very favorable natural climate, including high mountain and foothill areas, steppes and deserts, forests and groves, rivers, natural and artificial lake basins, large agricultural areas with modern urban planning. the image of anthropogenic landscapes expressed in itself also plays an important role in the cultural development of mankind. There is a great potential for the development of tourism in the unique nature of our country, national reserves, mountainous areas. In particular, the development of medical tourism, pilgrimage, car tourism and ecotourism will give a great impetus to the development of not only the economy but also the social sphere. [1]
Great work is being done in the country to develop tourism, including the construction of four- and five-star hotels that can provide a high level of service to tourists, and try to attract more tourists in the field of pilgrimage, ecology, agriculture, gastronomy, sports and local tourism.

One of the important factors contributing to the development of tourism is the use of modern computer programs that allow to automate the activities of tour operators and save unnecessary costs. The connection of tour operators to international global information systems based on GPS-position to offer tourism services, as well as the creation of local services is an important factor in increasing the tourist attractiveness of Uzbekistan. As a result, the creation of social and advertising videos, documentaries, as well as television programs about the nature, history, scholars and thinkers, attractions, national cuisine, customs and traditions of our country, their dissemination to the general public is important in the development of tourism and tourism.

According to statistics, the share of young people among active tourists around the world is growing. If in 2019 the number of tourists worldwide will reach 1.5 billion. of which 25 per cent were tourists under the age of 30. In Uzbekistan, by the end of 2020, 1.5 million foreign tourists visited, of which more than 1.5 million were young people. The average age of tourists visiting our country in 2010 was 60 years, and today it is 45 years. This shows that the number of young people visiting our country is growing. [2]

In accordance with the Presidential Decree "On measures to further develop the tourism industry in the Republic of Uzbekistan" dated August 15, 2019, to create favorable conditions for attracting young tourists to our country, to organize cultural and entertainment events, to create a system of benefits for young tourists as well as the concept of youth 
PEDAGOGY AND MODERN EDUCATION: TRADITION, EXPERIENCE AND INNOVATION - INTERNATIONAL CONFERENCE

Published: February 05, 2021 | Pages: 53-57

tourism development, which includes the construction of appropriate infrastructure.

As a result of efforts to develop domestic tourism and popularize youth tourism in our country, in 2018 the number of local tourists exceeded 14 million. In order to attract young tourists to our country, there is a need to study their wishes, as well as to create adequate conditions and infrastructure, based on their requirements. In this regard, the Presidential Decree pays special attention to the development of youth tourism in Uzbekistan, and given the urgency of the issue, clearly defines the priority measures to be taken in this regard and the task of their consistent implementation, villages and neighbourhoods (makhallas)are being established. Young tourists will also have the opportunity to get acquainted with rural life, nature and traditions through the organization of "Tourist Houses".

Development of the Concept for the development of youth tourism in Uzbekistan will further develop the types of tourism in our country. [2]
In particular, President Shavkat Mirziyoyev noted that tourism is one of the most profitable types of business in the world economy, and identified a number of problems in the development of tourism in our country.

Tourists and residents of our country visit the unique resorts of Chimgan, Bostanlyk, Zaamin, Bakhmal, Aral Sea, Aydarkol, Syrdarya, Kashkadarya, Naryn and other rivers, in the deserts of Kyzylkum, Mirzachul, large sums of money are required to build many camps to organize. The hotel fund in the country is $\mathbf{2 9 . 2}$ thousand places, so in spring, summer and autumn there is a lack of places to rest, vacationers are forced to spend the night in uncomfortable conditions or return on the same day, which is a convenient way to solve this problem.

We have issued a patent for the industrial design "Manufacture of cars, trailers in the national style" by the Intellectual Property Agency of the Republic of Uzbekistan for convenient transportation, accommodation for tourists, pilgrims and vacationers. (29.12.18y) № SAP 01861.
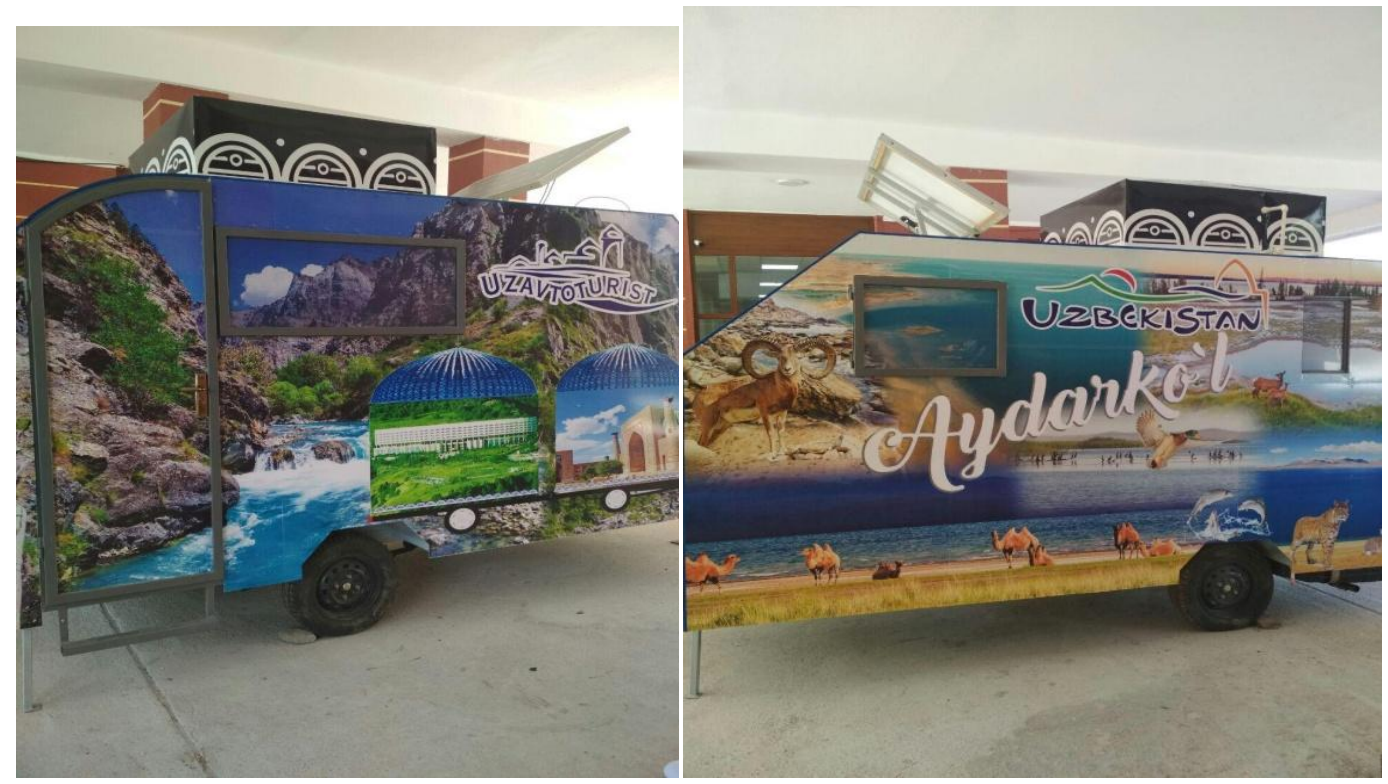
PEDAGOGY AND MODERN EDUCATION: TRADITION, EXPERIENCE AND INNOVATION - INTERNATIONAL CONFERENCE

Published: February 05, 2021 | Pages: 53-57

Based on the Resolution of the President of the Republic of Uzbekistan dated July 18, 2018 № PP-3855 "On commercialization of the results of scientific activities", the leadership of the Jizzakh State Pedagogical Institute allocated 37 million sums for the production of "national style" trailers. UZS were allocated for the preparation of a national-style car trailer. It has a double, triple room, uninterruptible power supply via solar panel, 300 liter water supply, bed, folding sofa, gas stove, TV, shower and bathroom. 60 million for each room to prepare a place for tourists in hotels. UZS, the price of the car trailer we offer for production is much cheaper and it can be placed in natural landscapes, rivers, lakes and deserts that tourists want.

Tourists visiting our country will be able to rent car trailers for our citizens, which will allow them to travel, visit, hunt and relax, which will help increase the number of domestic and foreign tourists.

Food tracks Delivery of "Uzbek and Jizzakh (other regions) national dishes" to tourists, vacationers, pilgrims coming and going to Uzbekistan and Jizzakh region on their orders will contribute to the development of gastronomic tourism, as well as the creation of additional jobs.

Today, the selling price of such trailers on the world market is 10-40 thousand US dollars. Car trailers can be exported to neighboring countries, as such road trailers are not manufactured in these countries.

\section{CONCLUSION}

As a result of this innovative idea, a new Uzavtoturist tourist route has emerged, which will significantly increase the number of tourists, pilgrims and vacationers and include many new tourist destinations, as well as the sale, service and rental of cars. allows you to create a system.

\section{REFERENCES}

1. Address of the President of the Republic of Uzbekistan Shavkat Mirziyoyev to the Oliy Majlis. December 2018.

2. OFFICIAL WEBSITE OF THE STATE COMMITTEE FOR TOURISM DEVELOPMENT OF THE REPUBLIC OF UZBEKISTAN-

https://uzbektourism.uz/

3. R. X. Ayupov, G. R. Boltaboeva "Directions of innovative development in small business and entrepreneurship" T .: TMI, 2018.

4. Botirov Bakhtiyor Fayzullaevich, \& Usmanov Azamat Juraboevich. (2020). MELON IN UZBEKISTAN - ECONOMIC EFFECTIVENESS OF INTRODUCTION OF "MELON, WATERMELON SYRUP", "WATERMELON HONEY", "MANGO" BEVERAGE FROM WATERMELONS. INTERNATIONAL JOURNAL OF DISCOURSE ON INNOVATION, INTEGRATION AND EDUCATION, 1 (4), 136-138. Retrieved from

5. Usmanov, A. (2020). UZBEKISTAN A UNIQUE TOURIST COUNTRY: HISTORICAL EVIDENCE, OPPORTUNITIES AND PROSPECTS Pp. 27-32. Archive Nauchnyx Publications JSPI, 1 (13), 1-143. izvlecheno ot https://science.i-

edu.uz/index.php/archive_jspi/article/v iew/3415

6. Alibekov, L. A., Alibekova, S. L., Nazarov, I. K., \& Gudalov, M. R. (2012). About some regularities of geosystems' degradation in Central Asia. Oecologia Montana, 21(1), 42-44.

7. Mirkomil, G., Bakhtiyor, Z., \& Dilfuza, I. (2020). Predicting Changes In Landscapes Around The AydarArnasay Lake System. The American Journal of Engineering and Technology, 2(10), 6-12. 
PEDAGOGY AND MODERN EDUCATION: TRADITION, EXPERIENCE

AND INNOVATION - INTERNATIONAL CONFERENCE

Published: February 05, 2021 | Pages: 53-57

8. Gudalov, M., \& Gozieva, M. (2020, December). Development Of Tourism In Zaamin National Nature Park By The Cluster Method. In INTERNATIONAL SCIENTIFIC AND CURRENT RESEARCH CONFERENCES (pp. 111-114).

9. Gudalov, M., \& Gozieva, M. (2020). Ways to develor modern ecoturism in the Zamin basin. International engineering journal for research \& development, 5 . 


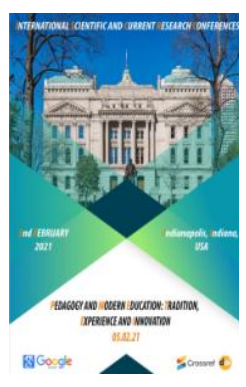

\title{
Rhinoplasty In Combined Deformations Of The Nose
}

\author{
J.A. Djuraev \\ Senior Lecturer Department of Otolaryngology and stomatology Tashkent Medical Academy \\ Tashkent, Uzbekistan \\ Sh.F. Fayozov \\ Master student Department of Otolaryngology and stomatology Tashkent Medical Academy \\ Tashkent, Uzbekistan
}

\section{ABSTRACT}

Rhinoplasty is one of the most difficult sections of plastic surgery and, above all, because the nose is the most open and visible part of the face, the smallest flaws of which are obvious.

\section{KEYWORDS}

rhinoplasty, deformities of the nose, nasal bones, surgery.

\section{INTRODUCTION}

Improving the cosmetic results of surgical treatment of combined deformities of the pyramid of the nose through the use of new technologies of rhinoplastic operations

\section{MATERIALS AND METHODS}

The study was based on 12 patients from the TMA multidisciplinary clinic, who underwent rhinoplasty operations for combined deformities of the pyramid of the nose in the period from 2020 to 2021. For the study, the main and control groups of patients were formed, each of which consisted of 6 patients. Both groups included patients with the following combined nasal deformities: rhinokyphoscoliosis (humped, crooked nose); rhinolordosis with rhinoscoliosis (saddle nose, crooked nose); rhinokyphosis with rhinolordosis (a humped nose with a simultaneous depression of the back); rhinolordosis with rhinokyphosis and rhinoscoliosis (saddle nose with a hump and retraction of the back); other combinations of deformities of the pyramid of the nose, including combinations with cicatricial deformity. In the operations performed for combined deformities of the nose in the main group, a number of specially designed instruments were used: a guiding instrument for removing the hump of the nose; a guiding 
PEDAGOGY AND MODERN EDUCATION: TRADITION, EXPERIENCE AND INNOVATION - INTERNATIONAL CONFERENCE

Published: February 05, 2021 | Pages: 58-59

instrument for endonasal removal of the nasal hump; an instrument for mobilizing the nasal bones.

\section{RESULTS OF THE STUDY}

The greatest value in assessing the effectiveness of surgical technologies for the treatment of combined nose deformities belongs to the comparison of the number of residual or repeated nose deformities after rhinoplastic surgeries performed using different methods. Therefore, the assessment of the cosmetic effectiveness of the developed and standard technologies in the main and control groups was carried out by comparing the number of residual postoperative nose deformities.

\section{CONCLUSIONS}

The use of new technologies of rhinoplasty and new instruments for combined deformities of the pyramid of the nose seems to be a promising direction in the development of rhinoplastic surgery and can significantly increase the efficiency of operations by reducing the percentage of residual and repeated deformities of the nose.

\section{REFERENCES}

1. Jumanov, Daulet Azadbek Ugli, et al. "International Journal of Biological and Pharmaceutical Sciences Archive." International Journal of Biological and Pharmaceutical Sciences Archive 1.1 (2020): 011-015.

2. VOHIDOV, Ulugbek Nuridinovich, et al. "Current issues of the treatment of chronic polypous rhinosinusitis." Journal of Biomedicine and Practice 2.5 (2020).

3. Kurbonov, Yokubjon Khamdamovich, Shukhrat Abdujalilovich Boymuradov, and Jamolbek Abdukakharovich Djuraev. "Overview Of Comprehensive Treatment of Acute Purulent-
Inflammatory Diseases of The Face And Neck." The American Journal of Medical Sciences and Pharmaceutical Research 3.01 (2021): 15-23.

4. Vohidov, U. N. "Djuraev JA ugli, Makhsitaliev, MI, \& Khamidjanov, s. O.(2020). Current issues of the treatment of chronic polypous rhinosinusitis." Journal of Biomedicine and Practice 2.5.

5. Makhsitaliev, Mukhammadbobur, et al. "The Functional State of The Mucous Membrane of The Nasal Cavity And Paranasal Sinuses After Radical And Minimally Invasive Surgical Interventions." The American Journal of Medical Sciences and Pharmaceutical Research 3.01 (2021): 31-40.

6. Шаумаров, А. 3., Х. Э. Шайхова, and ж. А. Джураев. "Assessment of the influence of nose tamponade on quality of life in the early postoperative period after septoplasty." Uzbek medical journal 5.1 (2020).

7. Жамолбек, Джураев Абдукаххорович, Хасанов Саидакрамович Улугбек, and Вохидов Нуридинович Улугбек. "Morphological characteristics of the mucous membrane of the nose and paranasal sinuses in case of chronic rhinosinusitis." Uzbek medical journal 5.1 (2020). 


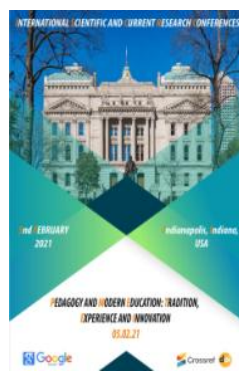

\title{
Features Of The Course Of Chronic Tonsillitis In Rhinosinusitis
}

\author{
J.A. Djuraev \\ Senior Lecturer Department of Otolaryngology and stomatology \\ Tashkent Medical Academy Tashkent, Uzbekistan \\ F.N. Norjigitov \\ Master student Department of Otolaryngology and stomatology Tashkent Medical Academy \\ Tashkent, Uzbekistan
}

\begin{abstract}
Rhinosinusitis is a bacterial or viral infection of the mucous membrane of the cavity and paranasal sinuses; it occurs in children and adults with the same frequency in all age groups. Rhinosinusitis, as one of the forms of upper respiratory tract infection, is perhaps the most common pathology faced by local therapists and pediatricians. According to American researchers, $4.6 \%$ of all visits to a general practitioner occur in cases of rhinosinusitis. The presence of 2 to 4 episodes of acute rhinosinusitis throughout the year indicates a recurrent course of the disease. According to some foreign authors, latent forms of sinusitis in adults account for 57 to $86 \%$ of cases. According to some researchers, Streptococcus pneumoniae and Haemophilus influenzae account for $70 \%$ of acute sinusitis in children. For many decades, the question of the choice of tactics for the treatment of hypertrophy of the pharyngeal tonsil (adenoids) and hypertrophy of the palatine tonsils (chronic tonsillitis) remains open. Chronic diseases of the lymphopharyngeal ring are the dominant pathology in which children are observed by an otolaryngologist and pediatrician.
\end{abstract}

\section{KEYWORDS}

Rhinosinusitis, mucous membrane, paranasal sinuses, nasal breathing.

\section{INTRODUCTION}

\section{Purpose of the study}

Prove that the cause of tonsillitis is chronic rhinosinusitis, which is latent and manifests edema (hyperplasia) of the turbinates.

\section{MATERIALS AND RESEARCH METHODS}

A total of 20 people were examined (15 children, 5 adults). Three children were examined with a diagnosis of adenoiditis (grade $2-3$ adenoid hypertrophy - 100\%). There 
was no history of acute rhinosinusitis. At the age of 2-5 years - 10 people. At the age of 6-12 years - 5 people. Difficulty nasal breathing periodically - 12 people. Difficulty nasal breathing constantly - 8 people. Of these, adenotomy was performed 1 year ago - 1 person, from 3 to 5 years ago - 3 people. The hypertrophy of the palatine tonsils of the 2nd3 rd degree - in 95\%, hyperplasia of the epithelium of the posterior pharyngeal wall in $51 \%$, a history of recurrent laryngitis - in $10.2 \%$ regional lymphadenitis of the submandibular, tonsillar, cervical lymph nodes - in $72 \%$ was associated. In clinical practice, the above nosological units in their pure form are extremely rare. Systemic reactions from the peripheral part of the immune system were revealed: 1. Adenoiditis, tonsillitis, regional lymphadenitis, hyperplastic pharyngitis. Adenoiditis, recurrent laryngitis (often with stenosis), regional lymphadenitis. 2. Adenoiditis, hyperplastic pharyngitis, recurrent bronchitis, etc. When examining the nasal cavity, attention is drawn to edema (hypertrophy) of the turbinates - in 20 (100\%); bilateral edema of only middle turbinates - in 2; edema of only the inferior turbinates - in 6, of which edema of the inferior turbinates on both sides - in 1, edema of the inferior turbinate on one (or mainly on one side) - 13. Concomitant changes - edema of the middle and inferior turbinates - in 5 All children underwent bacteriological and cytomorphological examinations of nasal swabs. X-ray of the paranasal sinuses. Also examined 5 adults with diagnoses: chronic pharyngitis (hyperplastic, mixed) - 1, chronic pharyngitis of the lateral pharyngeal ridges - 1 , periodic hoarseness - 3, chronic laryngitis - 2, chronic tonsillitis, hypertrophy of the tonsils, deep lacunae, plugs in the lacunae - 4 . Examination of the nasal cavity in adults revealed edema of the inferior turbinates - on one or predominantly one (with bilateral edema) side - in 3. Additional research methods: MPT, CT of the paranasal sinuses, cytomorphological and bacteriological examinations of nasal swabs.

\section{RESEARCH RESULTS}

The radiographs of the paranasal sinuses in children revealed changes characteristic of rhinosinusitis - parietal or total darkening of the ethmoid and maxillary sinuses. In smears from 95 to $100 \%$ of neutrophils, cocci from + to ++++ In bacteriological research, St. aureus, Str. pneumoniae, E. coli, Haemophilus influenzae. As a result of the study, in adults, in $100 \%$ of cases, changes in the paranasal sinuses from parietal to total darkening in the maxillary, ethmoid sinuses were revealed. And also the phenomenon of pansinusitis (15\% of cases). In $73 \%$ of cases, hyperplasia of the inferior turbinate is noted contralateral hyperplasia and edema in the maxillary sinus. Bacteriological research highlighted - st. aureus, str. pneumoniae, M. catarrhalis, str. pyogenes, $\mathrm{H}$. influenzae. Cytomorphological examination: neutrophils - from 70 to $100 \%$.

Thus, changes on the part of lymphoid organs: chronic adenoiditis, chronic tonsillitis, chronic hyperplastic pharyngitis, chronic pharyngitis of the posterolateral pharyngeal ridges, chronic laryngitis, regional lymphadenitis (as nosological units and their combinations) are systemic reactions from the peripheral part of the immune system and indicate for the presence of a chronic inflammatory process in the paranasal sinuses, which occurs, including in a latent form. These reactions may be markers of latent chronic rhinosinusitis. These changes can be used for additional diagnostics in case of hypertrophy (or predominant hypertrophy) of the inferior turbinate on one side revealed during examination of the nasal cavity. In this case, it is advisable to X-ray examination of the sinuses and laboratory cytomorphological and bacteriological examination of nasal swabs. If parietal or total darkening of the maxillary sinus, contralateral hypertrophy (or predominant hypertrophy) of the inferior turbinate, neutrophilic leukocytosis during cytomorphological examination and pathogenic microflora during bacteriological examination are detected, 
PEDAGOGY AND MODERN EDUCATION: TRADITION, EXPERIENCE AND INNOVATION - INTERNATIONAL CONFERENCE

Published: February 05, 2021 | Pages: 60-62

chronic rhinosinusitis is diagnosed, which proceeds latently.

\section{REFERENCES}

1. Djuraev, Jamolbek Abdukaxorovich, et al. "Results of Allergological and Immunological Research in Patients with Polipoid Rhinosinusitis." Asian Journal of Immunology (2020): 34-40.

2. Botirov, A. J., et al. "Clinical and morphological results of xenografts to use in myringoplasty." The International Tinnitus Journal 24.1 (2020): 1-6.

3. Djuraev, Jamolbek Abdukhahharovich, Ulugbek Saidakramovich Khasanov, and Ulugbek Nuridinovich Vokhidov. "The prevalence of chronic inflammatory diseases of the nose and paranasal sinuses in patients with myocarditis." European Science Review 5-6 (2018): 147-149.

4. Shamsitdinova, M. (2020). IMPLEMENTATION OF IT AND ICT INTO EDUCATION: MULTIMEDIA TECHNOLOGIES IN CREATING AND USING ELECTRONIC BOOKS. Theoretical \& Applied Science, (11), 510.

5. Djuraev, J. A., et al. "Results of an immunogistochemical study in patients with polipoid rhinosinusitis." European Journal of Molecular \& Clinical Medicine 7.2 (2020): 2526-2541.

6. Khasanov, U. S., and J. A. Djuraev. "Morphological characteristics of chronic polypous rhinosinusitis." CUTTING EDGE-SCIENCE (2020): 30.

7. Esonovna, L. D., Anvarovna, N. M., Sayidmahamadovna, S. N., Alimullaevna, N. F., \& Kakhramanovna, S. N. (2020). Pragmatic features of official texts and documents of the uzbek language. ANGLISTICUM. Journal of the Association-Institute for English Language and American Studies, 9(7), 27-34.
8. Narmurotov, Bakhtiyar Karshievich, Shukhrat Abdujalilovich Boymuradov, and Jamolbek Abdukakhkhorovich Djuraev. "Comparative Characteristics Of Rheological Properties Of Blood In Combined Face Injuries Before And After Treatment." The American Journal of Medical Sciences and Pharmaceutical Research 3.01 (2021): 67-75.

9. Nigmatov, Iftikhor Obidjonovich, et al. "Post-Traumatic Defects And Face Deformations: Features Of Diagnostics And Treatment." The American Journal of Medical Sciences and Pharmaceutical Research 3.01 (2021): 55-66. 


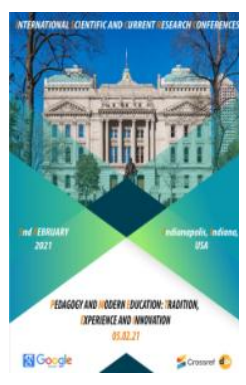

\title{
Aydar-Arnasay Lakes System Soil Structure And Its Chemical Composition
}

\author{
Dilfuza Imomova \\ Associate Professor Candidate of Biological Sciences, Jizzakh State Pedagogical Institute \\ named after Abdulla Qodiriy. \\ Shamsiya Imomova \\ Lecturer Jizzakh branch of the National University of Uzbekistan named after Mirzo Ulugbek
}

\section{ABSTRACT}

The soil structure of the Aydar-Arnasay lake system and its features are described. As a result of the analysis of the chemical elements of soil samples taken from the Boymurad fortress and Arnasay district, the amount of 33 macro- and microelements was determined for the first time.

\section{KEYWORDS}

Aydar-Arnasay lake system, elements, neutron-activation analysis, soil, ecosystem, monitoring

\section{INTRODUCTION}

The shores of the Aydar-Arnasay lake system, located at the foot of the Nurata ridge, are located in the desert part of Navoi and Jizzakh regions. The separation of the Aydar-Arnasay basin as a whole geosystem and the transfer of its natural boundaries is a rather complicated issue. The southern boundary of the Aydar-Arnasay basin is somewhat clear and passes through the foothills of the Nurata Mountains. The natural boundaries of the western, northern and eastern sides of the Aydar-Arnasay Basin were traversed through areas where changes in soil and vegetation were observed under the influence of groundwater from the Aydar-Arnasay Lakes System (AALS).
The western boundary of the Aydar-Arnasay basin corresponds to the eastern part of the Kyzylkum desert. Here, the areas adjacent to the naturally formed sandy soils and the saline sands formed under the influence of AALS were taken as the boundary of the basin.

\section{THE MAIN FINDINGS AND RESULTS}

The north-western part of the northern borders of the basin is bordered by the Eastern Kyzylkum, the northern part crosses the state borders of Uzbekistan and Kazakhstan, and the northeastern part is directly connected with the Sandy Desert. In crossing the border across the northern region, the exchange area of unsalted sandy 
PEDAGOGY AND MODERN EDUCATION: TRADITION, EXPERIENCE AND INNOVATION - INTERNATIONAL CONFERENCE

Published: February 05, 2021| Pages: 63-67

soils with saline sandy soils under the influence of AACT and, consequently, the exchange area of psammophytic plants with halophyte plants became the basis for crossing the border. The eastern boundaries of the Aydar-Arnasay basin correspond to the interchangeable areas of light gray soils cultivated with saline sandy soils.

The area is mainly covered with light gray soils, sandy soils and saline soils. Light gray soil type In the lowest areas of the region due to climate change from bottom to top, light gray soil is often composed of lyoss sands, the top layer of grass is light gray, and among the soils there are different types of saline soils. When the amount of salts in the soil exceeds $3 \%$, salts are formed, as a result of which the soil surface is covered with white and thin layers of salt. This is because in places where groundwater is close to the surface, water evaporates due to evaporation, and salts continue to accumulate on the soil surface, resulting in the formation of salts. Saline soils are rich in chlorine, sulfate and sodium salts, which are rapidly soluble in water, which worsens its chemical properties. Humus has almost no humus, only in humid and swampy soils a humus layer is formed. In sandy soils, the surface consists of $8-10 \mathrm{~cm}$ of scattered sand, and the plant roots do not branch here. Humus and nutrients are scarce in sandy desert soils. The humus content is $0.3-0.6 \%[1]$.

The climate of the region is sharply continental, reflecting the climate of the plains - desert and mountainous areas, with hot summers, cold winters and relatively mild. According to perennial weather data, the average January temperature is $1-40 \mathrm{C}$, the minimum temperature is $270 \mathrm{C}$, the average monthly temperature in July is $26-280$ C, and the maximum is $450 \mathrm{C}$. The average annual rainfall is $400-500 \mathrm{~mm}$ in the south and $250-$ $300 \mathrm{~mm}$ in the north [2].
The vegetation period of plants lasts $240-260$ days. The relative humidity is $70-80$ percent in winter and 10-30 percent in summer. [3].

The mineral, organic and some chemical elements of the soil chemical composition of the Aydar-Arnasay lake system vary, the mineral part of which is primary (quartz, feldspar, amphiboles, pyroxine, mica, etc.), secondary (montmorillonite, kaolinite, hydroslide, etc.). k.) and minerals and an organic structure. Dissolved substances occur in ionic, molecular, and colloidal forms. One of the main properties of soil is its acidity, the presence of hydrogen ions in the soil solution, as well as hydrogen and aluminum exchange ions in the soil absorption complex, which is important in the metabolism of soil microflora during vegetation [4].

The research was conducted in September 2020 on the basis of soil samples from the area around the Boymurad fortress of the Aydar-Arnasay lake system and soil water samples from the territory of Arnasay district. Soil samples for laboratory analysis were prepared at the Institute of Bioorganic Chemistry of the Academy of Sciences of the Republic of Uzbekistan and carried out at the Institute of Nuclear Physics using neutronactivation analysis in the VVR-SM research reactor.

Samples were prepared in the following order: each soil sample was taken in a separate polyethylene container, and a brief description of the time and place of their collection was recorded. The required amount was then ground in a porcelain vessel under laboratory conditions, dried at $60^{\circ} \mathrm{C}$ and sieved with a $2 \mathrm{~mm}$ sieve. Using the quarto method, soil samples were taken for detection of short-lived isotopes for neutron-activation analysis - from 20-30 mg, for detection of medium and long-lived isotopes - from 50-70 $\mathrm{mg}$. Each measured sample was then placed in moistened plastic bags and sent to the VVR$S M$ research reactor for neutron-activation 
PEDAGOGY AND MODERN EDUCATION: TRADITION, EXPERIENCE

AND INNOVATION - INTERNATIONAL CONFERENCE

Published: February 05, 2021 | Pages: 63-67

analysis to determine its chemical composition.

As a result of laboratory analysis, the content of 33 macro- and microelements in soil samples around the Aydar-Arnasay lake system was determined (table).

\begin{tabular}{|c|c|c|}
\hline Elements & $\begin{array}{l}\text { A soil sample around the Boymurod } \\
\text { fortress }\end{array}$ & Soil sample of Arnasay district \\
\hline As & 2,9 & 3,7 \\
\hline $\mathrm{Au}$ & $<0,001$ & $<0,001$ \\
\hline $\mathrm{Ba}$ & 310 & 480 \\
\hline $\mathrm{Br}$ & 70 & 2,8 \\
\hline $\mathrm{Ca}$ & 93500 & 68300 \\
\hline $\mathrm{Ce}$ & 22 & 27 \\
\hline $\mathrm{Co}$ & 3,9 & 4,9 \\
\hline $\mathrm{Cr}$ & 21 & 62 \\
\hline $\mathrm{Cs}$ & 1,7 & 1,9 \\
\hline Eu & 0,38 & 0,57 \\
\hline $\mathrm{Fe}$ & 10100 & 13200 \\
\hline $\mathrm{Hg}$ & $\mathrm{H} / \mathrm{O}$ & $\mathrm{H} / \mathrm{O}$ \\
\hline K & 9700 & 6500 \\
\hline La & 12 & 16 \\
\hline Lu & 0,19 & 0,13 \\
\hline $\mathrm{Mn}$ & 217 & 80 \\
\hline
\end{tabular}

Amount of chemical elements in some soil samples around Aydar-Arnasay lake system, $\mathrm{mkg} / \mathrm{I}$ 
PEDAGOGY AND MODERN EDUCATION: TRADITION, EXPERIENCE

AND INNOVATION - INTERNATIONAL CONFERENCE

Published: February 05, 2021 | Pages: 63-67

\begin{tabular}{|c|c|c|}
\hline Mo & 3,8 & 1,0 \\
\hline $\mathrm{Na}$ & 42800 & 6600 \\
\hline $\mathrm{Nd}$ & 11 & 6,2 \\
\hline $\mathrm{Ni}$ & $<10$ & $<10$ \\
\hline $\mathrm{Rb}$ & 35 & 66 \\
\hline $\mathrm{Re}$ & 1,0 & 1,0 \\
\hline $\mathrm{Sb}$ & 0,50 & 0,50 \\
\hline Sc & 4,0 & 4,7 \\
\hline $\mathrm{Se}$ & $\mathrm{H} / \mathrm{O}$ & $\mathrm{H} / \mathrm{O}$ \\
\hline Sm & 1,8 & 1,8 \\
\hline $\mathrm{Sr}$ & 1200 & 290 \\
\hline $\mathrm{Ta}$ & 0,32 & 0,38 \\
\hline $\mathrm{Tb}$ & 0,26 & 0,3 \\
\hline Th & 3,2 & 5,2 \\
\hline$U$ & 3,5 & 1,5 \\
\hline $\mathrm{Yb}$ & 1,2 & 1,3 \\
\hline $\mathrm{Zn}$ & 35 & 36 \\
\hline
\end{tabular}

\section{CONCLUSION}

According to the results of neutronactivation analysis of some soil samples taken from the territory of Boymurad fortress and Arnasay district of Aydar-Arnasay lake system, the content of $\mathrm{Ca}, \mathrm{Fe}, \mathrm{K}$ and $\mathrm{Na}$ elements was significantly higher, Tb, Lu, Au were relatively low. The amount of biogenic chemical elements in the soil indicates that it has a direct impact on the diversity and vegetation of plant species distributed around the AydarArnasay lake system.

\section{REFERENCES}

1. Alibekov L.A. Natural geography of Central Asia. - Samarkand: 2006. 64-70 p.

2. Qodirov G. Transformation of meadow vegetation cover on the shores of Lake 
Published: February 05, 2021 | Pages: 63-67

Aydarkol. B.s.c. written for dissertation.disser. -2008. 21-37 b.

3. Baratov P., Mamatqulov M., Rafiqov A. Natural geography of Central Asia. Tashkent: Teacher, 2002. pp. 279-318.

4. Soviet Encyclopaedic Dictionary. - M: Sovetskaya ensiklopediya, 1981. - 1599 p.

5. Go'dalov M. Impact of Aydar-Arnasay lake system on landscapes // Dissertation for the degree of Doctor of Philosophy (PhD) in Geographical Sciences. 2009. - b. 17-24.

6. Danilova E.A., Zaredinov D.A., Kist A.A. and dr. Otsenka ekologicheskoy obstanovki $v$ Tashkentskoy oblasti $\mathrm{S}$ ispolzovaniem yaderno-fizicheskix metodov // Uzbekskoy fizicheskiy zhurnal, 2012. - №2. - p 124-130.

7. Gudalov, M., \& Zikirov, B. (2020). Metnods of studying the landscapes around the Aydar-Arnasay lake system. International engineering journal for research \& development, 5 .

8. Mirkomil, G., Lapasova, U., \& Umurzakova, G. (2020). Territorial Aspects of The Organization Of Ecotourism Routes In The Turkestan Ridge. The American Journal of Interdisciplinary Innovations and Research, 2(11), 87-90.

9. СИДДИКОВ, Р. Б. (2015). ТРАДИЦИИ И НОВАТОРСТВО В ИСЛАМСКОМ ОБРАЗОВАНИИ В НЕЗАВИСИМОМ УЗБЕКИСТАНЕ. Ислам В современном мире: внутригосударственный и международно-политический аспекты, 11(4), 241-248. 
PEDAGOGY AND MODERN EDUCATION: TRADITION, EXPERIENCE AND INNOVATION - INTERNATIONAL CONFERENCE

Published: February 05, 2021 | Pages: 68-71

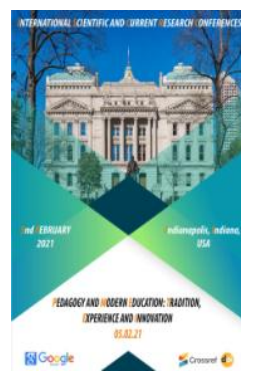

\section{Eco-Trail Routes In Zaamin National Park}

Mirkomil Gudalov

Phd, Candidate Of Geography Sciences Jspi Department Of Geography And Fundamentals Of Economics Uzbekistan

Matluba Gozieva

Director Of The Academic Lyceum Of Jizzakh Polytechnic Institute Uzbekistan

\section{ABSTRACT}

Eco-trail routes will be developed in the territory of Zaamin National Park with the study of unique corners of nature.

\section{KEYWORDS}

Turkestan ridge, Zaamin National Nature Park, nature reserve, eco-trail, route, nature, spruce, climate.

\section{INTRODUCTION}

In the western part of the Turkestan ridge is the Zaamin National Nature Park, the southern boundary of which runs along the ridge watershed and the Boykonyr River, and the northern boundary runs along the northern slope of Mount Molguzar. The National Nature Park consists of altitudes ranging from $1700-3570 \mathrm{~m}$. Administratively, it is located in Zaamin and Bakhmal districts of Jizzakh region.

If we look at the history of the Zaamin National Park, Sangzor, Bakhmal, Zaamin forests were first established in the early twentieth century. On the basis of these forestries in 1925-1926, the Guralash Nature Reserve was established on an area of about
8,500 hectares. It should be noted that the Guralash Nature Reserve is the first nature reserve in Uzbekistan.

Later, as the population around the reserve increased, more forests began to be cut down, and the environment was severely damaged as a result of overgrazing by the local population. In order to preserve the nature of this area, in 1959 the Zaamin Nature Reserve was established with an area of 15,600 hectares. An area of 31,500 hectares was added around the Zaamin Nature Reserve and in 1978 Zaamin was turned into a national park. 
PEDAGOGY AND MODERN EDUCATION: TRADITION, EXPERIENCE AND INNOVATION - INTERNATIONAL CONFERENCE

Published: February 05, 2021| Pages: 68-71

\section{THE MAIN FINDINGS AND RESULTS}

Today, the Zaamin National Nature Park is distinguished by the colorful and beautiful nature. There are 3 species of spruce (Turkistan, Zarafshan and Apricot) in the national park. The spruce tree kills germs in the air by releasing phytocidal substances from itself. That is why the mountain air is clean. In this treatment center, whooping cough (asthma), bronchitis are treated naturally.

The climate of the national park was studied on the basis of data from the Kolsoy meteorological station (2100). The climate of the region is characterized by cool and humid summers and moderately cold winters. In summer, the maximum temperature rises to 330S. This is $120 \mathrm{~S}$ lower than in Jizzakh. However, in winter the air temperature was observed to drop to -32 So. The vegetation period lasts up to 240 days and the sum of temperatures during the year is 2260 So. The relatively long growing season and cool weather conditions ensure plant diversity. The average annual rainfall is $405 \mathrm{~mm}$, of which $63 \%$ falls in spring, $17 \%$ in summer, $14 \%$ in autumn and $16 \%$ in winter. The thickness of the snow layer reaches $50 \mathrm{~cm}$ and lasts for 120 days a year without melting. The thickness and long layering of the snow leads to good wetting of the soil primer layer. For this reason, spruce and other trees and shrubs grow well.

Zaamin National Nature Park is very conveniently located by geographical location. The reason is that the territory of Zaamin National Park is located $24 \mathrm{~km}$ from Zaamin, $80 \mathrm{~km}$ from Jizzakh, $150 \mathrm{~km}$ from Samarkand and $264 \mathrm{~km}$ from Tashkent.

When entering the territory of Zaamin National Park, first of all, there are rivers with charming nature, such as Archamozor, Ayiklisay, Yongaksay and Olmasoy. Even firsttime visitors to the area can easily determine their natural geographical location, with the unique characteristics of the valleys.

At the beginning of the Archamozor gorge we can see a single tall spruce growing on the side of the road, at the beginning of Ayiklisay there is a statue of a bear, and at the beginning of Yongaklisoy we can see Boboyongoq, which is about 700 years old. These 3 ravines are located on the right side of the road, and if the trail runs along the road, it leads to the Sherbulak spring. The Almasay gorge, rich in wild apples, is located on the left side of the road, unlike the 3 ravines. At the beginning of the Almasoy valley, a unique recreation area is being built. It is worth noting that there is a spring, famous for its cold water, between the Yongaksay and Almasay ravines, on the side of the main road.

Tourists visiting the Zaamin National Park can also find here a mountain relief covered with thick pine forests, proud mountain peaks, waterfalls, karst tunnels, caves (there are more than 20 caves), rare plants and many species of animals. The eroded human-shaped rock formations (Forty Maidens), the superexotic karst processes that are not typical for the world's rare arid (arid) regions, "attract" tourists "lol", "plow" and "pits". .

Along with nature conservation and protection in the Zaamin National Park, great attention is paid to the development of international mountain tourism, ie ecotourism. The following projects should be implemented in the National Park to develop ecotourism without harming nature:

It is necessary to create a large-scale landscape map of the territory of the Zaamin National Park and to reflect the unique natural monuments;

- Identification of paths to unique natural monuments, their drawing and preparation of detailed instructions; 
- preparation of various eco-trails on foot and on horseback;

- Preparation of a separate schematic map for climbers and mountaineers. Using this schematic map, prepare a guide for the demonstration and movement of climbers and sports tourism facilities;

- Production of color photo booklets describing and advertising all tourist routes.

The National Park Administration has developed several eco-trail routes for the movement of tourists in the park area:

- Ayiqlisoy - Sherbulak eco-trail route

- Uriklisay-Tollisuv eco-trail route

- Miq Castle eco-trail route

- Sherbulak eco-trail route

- Boboyongok eco-trail route

- Waterfall eco-trail route

- A thousand-year-old spruce eco-trail route

- Four-lane eco-trail route

The above eco-trail will be able to observe all the fascinating nature of the environment as you move along the route directions. It is necessary to move without making noise when moving along the eco-trail, without damaging the flora and fauna. Below we list the most interesting ones in the Zaamin National Park, along the eco-trail route:

Ayiklisay-Sherbulak eco-trail route. This route travels from Ayiklisay to Gazaygalan Pass. During the trip, only the top of the mountain is hiked. Mountain animals include bears, wild boars, rabbits, and various birds.

Uriklisay-Tollisuv eco-trail route. From Uriklisay to Tollisuv. This route is planned for hikers to Takali Peak only on foot, enjoying the beauties of nature, short-term rest, setting up tents and a day of rest.

- Miq Castle is an eco-trail route. It starts from the village of Ettikechuv and walks along the river. When you go to Mixsoy, you can see the old, ancient Chinese castles that have been preserved there for centuries. Among the animals, jays, foxes, wolves and wild boars are common and are familiar with the characteristics of various caves.

\section{CONCLUSION}

Sherbulak-Chortangi eco-trail route. Zaamin Velvet road eco-trail route can be traveled by car and on a bicycle. The beautiful nature of Zaamin National Nature Park, its unique climate and wildlife do not leave anyone indifferent. When you reach the Chortangi gorge in this direction, you can see steep cliffs and various birds of prey. Black storks, partridges and other species of birds of prey are common here.

It is necessary to provide information on the rules for local and foreign tourists traveling along these eco-trail routes, as well as to install billboards in 3 languages, ie Uzbek, Russian and English, which operate independently without the help of a guide.

\section{REFERENCES}

1. Alibekov L, Alibekova S, Hazarov I, Gudalov M. About some regularities of degradation geosystems in Central Asia. Tatranka Javorina, Slovakia, 2012, Vol 21, № $-1,42-44 \mathrm{r}$

2. Gudalov M. Foundation of Aydar-Arnasay lakes system and their effects on the environmental landscape. Nature and Science.Volume 17, Number 11 November 25, 2019 USA New York.

3. Gudalov M., Zikirov B. Metnods of studying the landscapes around the Aydar-Arnasay lake system. International 
PEDAGOGY AND MODERN EDUCATION: TRADITION, EXPERIENCE

AND INNOVATION - INTERNATIONAL CONFERENCE

Published: February 05, 2021| Pages: 68-71

engineering journal for research \& development. Vol - 5, Issue - 7, 2020 India.

4. Gudalov M., Zikirov B., Imamova D. Predicting changes in landscares around the Aydar-Arnasay lake system. Accerted in the journal The American of Engineering and Technology. Volume - 02, Issue - 10, October 2020.

5. Gudalov M., Gozieva M. Ways to develor modern ecoturism in the Zamin basin. International engineering journal for research \& development. Vol - 5, Issue - 7, 2020 India.

6. Sharipov Sh, Gudalov M, Shomurodova Sh. Geolologic situation in the AydarArnasay colony and its atropny. Journal of Critical Reviews. Volume 7, Issue 3, 2020 Malaysia Kuala Lumpur.

7. Sharipov Sh, Shomurodova Sh, Gudalov $M$. The use of the mountain kars in the tourism sphere in cort and recreation zone of Chimgan-Charvak. Journal of Critical Reviews. Volume 7, Issue 3, 2020 Malaysia Kuala Lumpur.

8. Go'dalov, M. R. (2014). Nature of Jizzakh region and its protection.-T.:". Science and technology.

9. Курбанова, А. А. (2015). К ВОПРОСУ О ПРЕДМЕТАХ, ОСВЕЩАЮЩИХ ДРЕВНЮЮ ИСТОРИЮ УЗБЕКИСТАНА, ХРАНЯЩИХСЯ НЫНЕ В МУЗЕЕ АНТРОПОЛОГИИ И ЭТНОГРАФИИ ИМ. ПЕТРА ВЕЛИКОГО (КУНСТКАМЕРА) РОССИЙСКОЙ ФЕДЕРАЦИИ. Фундаментальные и прикладные исследования в современном мире, (105), 42-46.

10. Kobzeva Olga, Siddikov Ravshan, Doroshenko Tatyana, Atadjanova Sayora, Ktaybekov Salamat (2020) EASTERN AND WESTERN LOOK AT THE HISTORY OF THE SILK ROAD. Journal of Critical Reviews, 7 (9), 93-100. doi:10.31838/jcr.07.09.17
11. Сиддиков,
$\mathrm{P.}$
Б. (2019).
ПОЛИЭТНИЧЕСКАЯ ИНТЕГРАЦИЯ
ТУРКЕСТАНСКОГО КРАЯ В КУЛЬТУРНОЕ
ПРОСТРАНСТВО
РОССИЙСКОЙ
ИМПЕРИИ (НА ПРИМЕРЕ РУССКО-

\section{ТУЗЕМНЫХ \\ ШКОЛ). \\ In \\ КОММУНИКАТИВНАЯ КУЛЬТУРА: \\ ИСТОРИЯ И СОВРЕМЕННОСТЬ (рр. 240- 247).}

12. Gudalov, M., \& Gozieva, M. (2020, December). Development Of Tourism In Zaamin National Nature Park By The Cluster Method. In INTERNATIONAL SCIENTIFIC AND CURRENT RESEARCH CONFERENCES (pp. 111-114). 


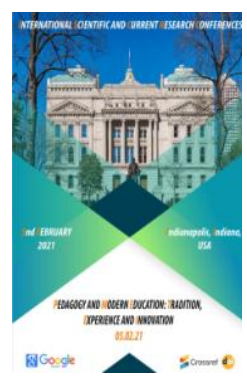

\title{
Tourist Potential Of Zaamin District
}

\author{
Zilola Abduhakimovna Sanakulova \\ Senior Lecturer Department Of General Pedagogy Jizzakh State Pedagogical Institute, \\ Uzbekistan \\ Mahfuza Sangirova \\ 1st Year Master's Degree Student In Geography Jizzakh State Pedagogical Institute, \\ Uzbekistan
}

\section{ABSTRACT}

About the natural geographical factors and objects and measures for their use, which are the basis for the development of tourism in the resort area of Zaamin.

\section{KEYWORDS}

Recreation, national park, Boboyongoq, "Suffa plateau”, Oktepa, Kultepa

\section{INTRODUCTION}

Today, we can say that tourism is one of the fastest growing industries in the world, as well as in Uzbekistan. As a strategic sector of the country's economy, favorable economic, organizational and legal conditions are being created throughout the country. A number of reforms are being carried out in the country to develop the tourism industry, create tourist zones and mountain tourism centers and increase the efficiency of their use. For example, the President of the Republic of Uzbekistan has announced a draft resolution on the activities of the tourist recreation zone Zaamin and measures to establish an international seasonal ski resort. In fact, Zaamin is a very interesting place for those who love to travel in nature. This district is one of the mountainous districts of Jizzakh region. The area is also famous for its fragrant and healing pine trees. According to experts, up to 2 tons of water accumulates around the roots of a single spruce. In addition, the maturity of this tree produces enough oxygen for a village during the day. Located at an altitude of 2,400 meters above sea level, 27,000 hectares of pine forests constantly saturate the air with oxygen. Pine extract is used to treat bronchial asthma, sore throats and a number of allergic diseases. The rich fauna of the area also feels free because of the spruce. In this case, it is safe to say that the beauty and generosity of the mountains of Zaamin depends directly on the spruce. Even in the hottest days of summer, the temperature in this place does 
not exceed 200 degrees, and at night it drops to 5-100 degrees. On the contrary, in winter the mountains are warm. But at night you have to feel the real breath of the cold. Therefore, this place is crowded with tourists in winter and summer.

\section{THE MAIN FINDINGS AND RESULTS}

In addition to all the unique natural beauties, this area is also famous for its ancient history. Here you can find the ruins of castles and monuments of different periods. However, the National Park, established in 1976 to preserve the unique nature of this place, is the main attraction. The total area of the park is $24,110,000$ hectares, most of which is forest. You can also find mountain ranges, hills and hills in the national park. The highest part of the ridge is Shavkartog, which is more than 4,000 meters high. One of the highlights of the park is the 700-year-old Boboyangak walnut tree. It is 20 meters high and almost 3 meters in diameter.

A very interesting cave was found in a village not far from the national park. Archaeologists have found the tools of primitive labor, and the walls of the cave are decorated with paintings.

Today, there are 3 sanatoriums, 4 summer camps, 4 hotels, 90 home hotels and more than 70 resorts in the foothills. In particular, there are 17 historical monuments and sacred sites in the district, such as Kok-tonli ota, Qurghontepa, Azlartepa, Boboyongok. There are also the remains of the city of Oktepa and Kultepa of the Karakhanid period, as well as the Peshagor cave with the oldest inscriptions on the walls. More than 4,500 historical exhibits found at these sites are housed in a museum in the district center.

For example, in 2019, more than 75,000 visitors visited Zomin. Despite the pandemic, more than 11,000 tourists came this year.
Memorial gifts in the Zaamin area include mysterious locked carvings, decorative bowls and many other interesting items. The potters delight tourists with dishes painted with unique local patterns. Also, the local people are ready to amaze the guests with their handicrafts.

The following is an example of the work being done to develop tourism in the region. \$100 million will be allocated for the Jizzakh free tourism zone and a recreation zone "Zomin" will be established in Jizzakh region. The Reconstruction and Development Fund will provide a $\$ 40$ million loan. The Suffa Plateau will host 2,400 international seasonal resorts and the Uriklisay tourist complex.

The fund will also receive a loan of $\$ 60$ million to finance investment projects for the construction of modern tourist infrastructure in the free tourist zone.

In the village of Duoba, 400 meters above sea level in Zaamin, a 27,000-hectare pine forest is being developed as a tourist infrastructure to treat bronchial asthma, sore throats and a number of allergic diseases.

\section{CONCLUSION}

In conclusion, every effort is being made to make the most of the district's tourism potential. In particular, on November 9, 2020, the Cabinet of Ministers adopted a resolution "On measures for integrated socio-economic development of Zaamin district of Jizzakh region in 2020-2022." This legal document envisages 98 in the field of industry, services, agriculture, 89 in the development of engineering and communication networks, 72 for the construction, repair and equipping of public facilities, improvement of irrigation and land reclamation systems. It is planned to implement 12 projects on the regulation of the district center on the basis of urban planning 
requirements. The resolution also raises the issue of establishing a tourist recreation zone "Zomin" on the Suffa plateau in the district. In particular, the organization of 4- and 5-star hotel complexes, modern cultural and health, trade, entertainment and engineering infrastructure facilities of tourist significance. At the same time, a 2,640-meter modern road will be built connecting the sanatorium on Zaamin Mountain with the ski area and the town under construction at the site. An amphitheater, a conference hall and a cinema will be built in this town. $250 \mathrm{~km}$ of roads will be repaired and built. The infrastructure created in this direction will be able to serve 1.3 million passengers. It is safe to say that in the future Zaamin will become one of the largest tourist centers in line with international standards.

\section{REFERENCES}

1. Sanakulova Zilola Abduhakimovna, Soibnazarova Mukaddas Norpulatovna. Modular training as pedagogical technology. Materials of the $\mathrm{X}$ International Scientific Conference. 2017

2. Soibnazarova Mukaddas Norpulatovna, Sanakulova Zilola Abdukhakimovna. Some psychological problems of observation in adolescence. Founders: OOO "Izdatelstvo Molodoy uchenyy" Kazan. 2016.

3. Alibekov L, Alibekova S, Hazarov I, Gudalov M. About some regularities of degradation geosystems in Central Asia. Tatranka Javorina, Slovakia, 2012, Vol 21, № $-1,42-44 r$

4. Gudalov M. Foundation of Aydar-Arnasay lakes system and their effects on the environmental landscape. Nature and Science.Volume 17, Number 11 November 25, 2019 USA New York.

5. Gudalov M., Zikirov B. Metnods of studying the landscapes around the Aydar-Arnasay lake system. International engineering journal for research \& development. Vol - 5, Issue - 7, 2020 India.
6. Gudalov M., Zikirov B., Imamova D. Predicting changes in landscares around the Aydar-Arnasay lake system. Accerted in the journal The American of Engineering and Technology. Volume - 02, Issue - 10, October 2020.

7. Gudalov M., Gozieva M. Ways to develor modern ecoturism in the Zamin basin. International engineering journal for research \& development. Vol - 5, Issue - 7, 2020 India.

8. Sharipov Sh, Gudalov M, Shomurodova Sh. Geolologic situation in the AydarArnasay colony and its atropny. Journal of Critical Reviews. Volume 7, Issue 3, 2020 Malaysia Kuala Lumpur.

9. Sharipov Sh, Shomurodova Sh, Gudalov $M$. The use of the mountain in the tourism sphere in cort and recreation zone of Chimgan-Charvak. Journal of Critical Reviews. Volume 7, Issue 3, 2020 Malaysia Kuala Lumpur.

10. Kurbanova, D. (2020). Tent Of The Emir Of Bukhara (Second Half Of The 19th Century)(History Of One Exhibit From The Collection Of The State Hermitage). The American Journal of Social Science and Education Innovations, 2(12), 180-183. 


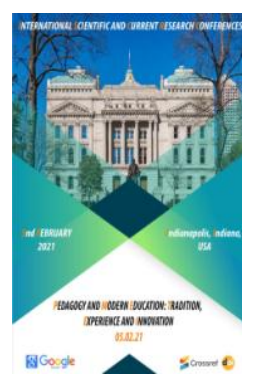

\title{
Rare Plants In The Turkestan Range (Dzhizak Regions) Republic Of Uzbekistan
}

\author{
Nasiba Karshiboeva \\ Jizzakh State Pedagogical Institute Jizzakh, Republic Of Uzbekistan, Uzbekistan
}

\section{ABSTRACT}

The article examines the rare plant species growing on the territory of the Turkestan ridge (Jizzakh region), included in the "Red Book" of the Republic of Uzbekistan

\section{KEYWORDS}

"Red Book" of the Republic of Uzbekistan, area, Pamir Alai, Turkestan ridge, Malguzar ridge, gene pool.

\section{INTRODUCTION}

The protection of the environment and the plant world is of great importance to humanity. Using nature, people change the natural landscape formed over the years and have a negative impact on it. The wrong attitude of the population to nature is also the reason for the reduction of plants.

Published the 4th edition of the "Red Book" of the Republic of Uzbekistan (2009). It includes 324 species of rare and endangered plants and fungi. In the 1998 edition of the "Red Book" of the Republic of Uzbekistan, 301 plant species are indicated.
Plants distributed in the mountain ranges of Molguzar, Western Pamir-Alai, Turkestan are included in the "Red Book" of the Republic of Uzbekistan. Turkestan ridge is located in the Jizzakh region (2045699), mainly in the Zaamin (28658 hectares) and Jizzakh (143874 hectares) regions.

Studied 31 species, which are included in 12 families of representatives of rare plants. When studying the inventory of rare and endemic species in the Jizzakh region, 67 species belonging to 22 families were identified [6].

Let's characterize several types of plants 
PEDAGOGY AND MODERN EDUCATION: TRADITION, EXPERIENCE AND INNOVATION - INTERNATIONAL CONFERENCE

Published: February 05, 2021| Pages: 75-78

- Astragalus Belolipova - Astragalus belolipovii Kamelin ex F.O. Khass. et N. Sulejm. Stemless plant $30-40 \mathrm{~cm}$. $\mathrm{H}$. Thornless leaves $20-30 \mathrm{~cm}$ long protruding white hairy, 15-20 paired. Peduncles are longer than leaves. Brushes are loose, $15-20$ flowers, $10-15 \mathrm{~cm}$ long. The calyx is bluish at the bottom, initially tubular, later swollen, white hairy $12-15 \mathrm{~mm}$ long. The flag is greenish-purple, 25-30 mm long with a rounded plate on top notched, wings 25-30 $\mathrm{mm}$ long slightly longer than the boat. Bob is unknown. Blossoms in June; bears fruit in July. Rarity 1.distributed in the Turkestan ridge of the Zaamin state reserve of the Jizzakh region. Grows in juniper, seed reproduction. The reasons for the change in the number and range have not been established. The species was cultivated by prof. I.V. Belolipov in the Botanical Garden of the Academy of Sciences of the Republic of Uzbekistan. Astragal A. speciesauratus Gontsch, A. knorringianus Boriss, A.plumatus Boriss, A. leptophysus Vved, grow in the Turkestan ridge. When studying the flora of the Zaamin State Reserve, 21 plant species were included in the "Red Book" of the Republic of Uzbekistan, and it was also recommended to include the species Astragalus russanovii in the next edition of the "Red Book" of the Republic of Uzbekistan [7].

- Shirach powerful - Eremurus robustus Regelis a strong perennial herbaceous plant 100-250 $\mathrm{cm}$ high with a shortened rhizome and radially spreading fusiform thickened roots. Leaves broadly linear, outer $4-8 \mathrm{~cm}$ wide, smooth. Raceme very dense, many-flowered, cylindrical, $35-120 \mathrm{~cm}$ long. Bracts are triangular. The lower pedicels are 1.5-2 times as long as the perianth. Tepals with 1 vein, light pink. The stamens are slightly shorter than the perianth. Fruit - spherical, smooth capsule $1.5-2.5 \mathrm{~cm}$ wide. It blooms in MayJune, bears fruit in July-August. Distributed in all ranges of the Pamir Alay. Mass collection by the population is the cause of changes in the number and range of the plant grows in fine-earth and fine-earth-stony slopes of the middle belt of mountains.

Occurs in single specimens and in small groups. Propagated by seed and vegetative. It is grown in the Botanical Garden of the Uzbek Academy of Sciences. Green-flowered shirach (E. chloranthus Popov) which belongs to the families Asphodelaceae (E. chloranthus Popov) grows in the Turkestan ridge on the upper part of the Guralash Say. The number and reason for the change have not been determined. Rarity level 0 . The plant is endemic. When studying and compiling the plants of the Zaamin State Reserve, the species Eremurus kaufmani is recommended to be included in the next edition of the "Red Book" of the Republic of Uzbekistan [7].

Ferula Fedchenkovskaya - Ferula fedtschenkoana Koso-Pol is a perennial polycarpic completely naked herb. The root is fusiform. Stem single or several, thin, often purple, corymbose branching in the upper part; branches are alternate, upper ones are opposite. Leaves are glaucous, soft, glabrous, 5-pinnately dissected; terminal lobes are narrow, 10-20 mm long. Terminal umbrellas 48 ray. Umbrellas are 10 -flowered. The calyx is short-toothed. Petals are yellow, oval, $1.4 \mathrm{~mm}$ long. Fruits are oblong oval, compressed from the back, glabrous, $6 \mathrm{~mm}$ long, $3.5 \mathrm{~mm}$ wide. Flowers in May, bears fruit in June. Distributed in the Turkestan and Molguzar ridges. Habitats - fine earth-gravelly northern slopes in the juniper belt. Occurs singly, 2-3 plants per $10 \times 10 \mathrm{~m}^{2}$. Seed reproduction. Rarity level 1 . Rare endemic species. 3 more Apiaceae species are found: F. sumbul (Kauffm.) Hoog.f. Zeravschania regeliana Korovin, Fergania polyantha (Korovin) Pimenov. When studying the species Kovrak (Ferula) [Avalboev 0. 2012]ferula helenae Rakhmankulov and Melibayev believe that the plant should be included in the "Red Book" of the Republic of Uzbekistan [4] . 
Corydalis severtsov -Corydalis sewerzowii Regel. - a perennial herb 5-12 cm in height with a flattened spherical angular tuber and an ephemeroid type of development. Stems 1-3. leaves are opposite, almost sessile, triply dissected twice, glaucous, glabrous. Flowers in a short brush, 2-5 each. corollas are orangeyellow, brown-red after flowering, 3-5 cm in length. The spur is thin, straight or slightly curved, up to $3 \mathrm{~cm}$ in length. The fruit is a capsule, oblong, slightly flattened, sharp, up to $2 \mathrm{~cm}$ long, $0.6 \mathrm{~cm}$ wide. Seeds $3-4 \mathrm{~mm}$ wide, shiny, round, slightly flattened, with filmy, caplike, sessile caruncle. Blooms in FebruaryMarch, bears fruit in April. Vegetation ends in May. It grows in clayey fine-earth gravelly slopes from foothills to the lower belt of mountains. The area of plants has greatly decreased in the Turkestan ridge. Rarity level 3 [2].

Cultivated in 1960 in the Botanical Garden. Belongs to the Fumariaceae family, included in the Red Book in 1984. Not included in the 2009 Red Book. The reasons for the change in the number and range are irrational procurement as a medicinal raw material, immoderate collection by the local population as an ornamental early flowering plant. According to the observation results, periods of growth (04/12/2020), flowering (04/20/20/20), fruiting (04/25/2020), vegetation (2.05-8.05) are visible. We recommend that the species Corydalis sewerzowii Regel be included in the next edition of the "Red Book" of the Republic of Uzbekistan .

\section{FINDINGS}

1. 31 species included in the "Red Book" of the Republic of Uzbekistan are identified as belonging to 12 families of rare and endangered plants included in the "Red Book" of the Republic of Uzbekistan in the ridges of the Western Pamir-Alai, Turkestan, Molguzar.
2. The study of species as a whole in such a territory creates the possibility of preserving the gene pool and the stability of the species of the range and the definition of the laws of their development.

3. Taking into account the above scientific research of the researchers, we recommend that the plant species Astragalus russanovii, Eremurus kaufmani, Ferula helenae, Corydalis sewerzowii be included in the "Red Book" of the Republic of Uzbekistan.

\section{REFERENCES}

1. Botirova L.A. Zomin suvhavzasining o'simliklar qoplami. Avtoreferat. biol. fan. nom. ilmiy darajasini olish uchun taqdim etilgan. Toshkent. 2012.

2. "Red Book" of the Uzbek SSR. vol. 2. Plants. Fan. Tashkent. 1984.118p.

3. O'zbekiston Respublikasi "Qizil kitobi" 1jild. O'simliklar va zamburug'lar. Chinor ENK. Toshkent.2009.

4. Rahmonqulov U., Avvalboyev O. O'zbekiston Respublikasi Jizzax viloyatining kamyob va yo'qolib borayotgan o'simliklari // Bioxilma-xillikni saqlashda muhofaza hududlarining roli.// Konferensiya materiallari. 4-5 iyun. 2012 yil 66-70 betlar.

5. Tojiboyev K. Sh, Qodirov R.U. "O'zbekiston lolalari" Toshkent. Sharq "nashriyoti. 2010.

6. Tojiboev K.Sh., Beshko N.Yu. Jizzakh and Navoi provinces of the Republic of Uzbekistan. Biodiversity of Uzbekistan monitoring and use. Tashkent. 2007

7. Esankulov A.S. Flora of the Zaamin State Reserve. Abstract of diss. for the degree of Candidate of Biological Sciences. Tashkent. 2012.

8. Adilov, J. K. (2019). THE CAMPAIGN OF ALEXANDER BEKOVICH-CHERKASSKY IN THE WORKS OF VV BARTHOLD. Theoretical \& Applied Science, (10), 572574. 
Published: February 05, 2021 | Pages: 75-78

9. Adilov, J. K. (2019). THE CAMPAIGN OF

ALEXANDER BEKOVICH-CHERKASSKY IN

THE WORKS OF VV BARTHOLD.

Theoretical \& Applied Science, (10), 572-

574.

10. Gudalov, M., \& Gozieva, M. (2020, December). Development Of Tourism In

Zaamin National Nature Park By The Cluster Method. In INTERNATIONAL SCIENTIFIC AND CURRENT RESEARCH CONFERENCES (pp. 111-114).

11. Kurbanova, D. (2020). Tent Of The Emir Of Bukhara (Second Half Of The 19th Century)(History Of One Exhibit From The Collection Of The State Hermitage). The American Journal of Social Science and Education Innovations, 2(12), 180-183. 


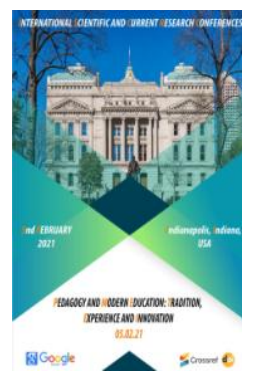

\title{
Functional Literacy In Living Challenges (Pisa Study)
}

\author{
Shakhnoza Akhmedovna Siddikova \\ Jizzakh State Pedagogical Institute, Uzbekistan \\ Zukhra Ziyatovna Yakhshieva \\ Jizzakh State Pedagogical Institute, Uzbekistan
}

\section{ABSTRACT}

The article gives the meaning of natural science literacy, considered in a broader sense as computer, political, economic literacy. The results are driven by the TIMSS (Third International Mathematic sand Science Study) and PISA (Programmer for International Student Assessment), an international mathematics and science study.

\section{KEYWORDS}

Natural science literacy, functional literacy, international studies.

\section{INTRODUCTION}

Science literacy is the ability of a person to take an active civic position on issues related to the natural sciences, and his willingness to take an interest in natural science ideas. A natural science literate person seeks to participate in a reasoned discussion of problems related to natural sciences and technology, which requires him to have the following competencies: to scientifically explain phenomena, evaluate and plan scientific research, scientifically interpret data, give evidence.

Substantiate the question arises: why do you need to change something? In modern society, it is necessary not only to write correctly, but to be able to adapt to changing working conditions and life support. Students' literacy rates are declining. The hope for learning more "later" does not bring success. All this complicates the process of adaptation to adulthood. The ability to read, write and count is no longer enough. Literacy is now fully called "functional", began to be considered in a broader sense: to include computer literacy, political, economic literacy. American researcher E.D.Hersh introduced the concept of "cultural literacy". As a result of painstaking research, he selected 4500 items, names, dates, events that Americans who consider themselves culturally literate should 
PEDAGOGY AND MODERN EDUCATION: TRADITION, EXPERIENCE AND INNOVATION - INTERNATIONAL CONFERENCE

Published: February 05, 2021 | Pages: 79-81

know. Thus, a cultured person with functional literacy should be able to solve life problems in various fields of activity.

\section{THE MAIN FINDINGS AND RESULTS}

Functional literacy is an indicator of social well-being. A high level indicates a certain cultural level of the society; low - is a warning of a possible social crisis.

The increased attention to the term functional literacy is due to the ongoing international research on the achievement of expected educational outcomes in mathematics and natural sciences TIMSS (Third International Mathematic sand Science Study) and the PISA (Programmer for International Student Assessment). The PISA International Studies Program is a skill assessment system for 15year-old students. PISA is a unique study that assesses not only the degree of mastering of educational material, but also the ability to use the acquired skills and knowledge to solve a variety of life problems, that is, the functional literacy of students. Three types of such literacy are tested: "reading literacy", "mathematical literacy", "natural science literacy".

The research is carried out once every three years - these are the so-called small cycles. In each, the focus (two-thirds of the testing time) is on one of three areas. In 2000 it was reading literacy, in 2003 it was mathematical, in 2006 it was natural science, in 2009 it was reading literacy again, that is, a new big nineyear cycle started.

The PISA program is held in 130 countries of the world every three years. In 2009, Kazakhstani schoolchildren were on the 59th position, now the goal is to move up 10 lines. So far, Japan, China, Singapore, Russia and the Netherlands have been in the lead for several years.
To basic competencies, i.e. skills to operate with knowledge of facts, formulas, laws, include literacy in reading, mathematics, and natural science.

To develop functional literacy, a teacher needs to work in the following areas:

the first direction: the development of tasks for functional literacy.

There are no functional literacy assignments in textbooks, so their development falls on the teacher's shoulders. Of course, the texts of the PISA assignments can be adapted. Although their use in a subject lesson is difficult. Therefore, it is better to carry out such tasks either as a warm-up or during class hours. All the more so since many of the texts are social, interesting and instructive.

Second direction: self-diagnosis, assessment for learning.

For this I use relay work. They used to be called "array jobs"; students are offered many tasks or problems, which he can solve according to his choice. The final test is made up of them: the more problems the student solved, the more likely they are to successfully solve the test.

Third direction: peer education + socialization. Students are already getting used to the comments of the teacher's assessments, and if in elementary school this acts as an encouragement, then in the middle and senior level the teacher's assessment of especially creative developmental tasks does not bring value to the child and does not contribute to his development. This is where peer-to-peer performance assessment helps. Using Bloom's taxonomy, the teacher sees at what level of growth and development a particular student is.

The fourth direction is working with discrete text. 
In geography, it is, first of all, working with a map, since anyone should be able to use a map for practical purposes. The methodology for the formation of skills to work with maps of various content includes: first, a deep mastery of the cartographic research method by students, for which it is necessary to provide for the performance of such tasks by students that would help them to understand the actions with which they are find a solution.

Take a trip on a physical map of Australia (choose the route yourself, use other maps in your work). Tell us what kind of nature will surround you and what kind of economic activity you will meet. Secondly, it is necessary to organize practical work with cartographic images displayed on the screens of school computers.

\section{CONCLUSION}

A student can learn to act only in the learning process, and the teacher's everyday work in the classroom, the educational models that he chooses, form the functional literacy of students. Therefore, the most important task in the development of the skill of a modern teacher is the formation of his functional competence, which includes deep theoretical training and practical experience in the productive use of modern educational models in the classroom, readiness for flexibility adaptation and modification, taking into account the individual and age characteristics of students and temporary needs.

\section{REFERENCES}

1. V. A. Slastenin Pedagogy - textbook. allowance. - M., 2001.

2. Likhaev B.T. Pedagogy: a course of lectures. - M., 2001.

3. V.S. Kukushin General foundations of pedagogy. - Rostov-on-Don, 2002.

4. N.V. Bordovskaya Pedagogy. - SPb., 2002.

5. Dann, G. (1996b) The Language of Tourism. Wallingford. CABI.
6. Yakhshieva Z.Sh., Djumabaeva J.Sh. Agritourism as a type of tourism. EPRA International Journal of Multidisciplinary Research IJMR Vol.6 August 2020.458$459 \mathrm{P}$.

7. Yakhshieva Z.Sh., Yakhshieva M.Sh. Ecotourism as a subsystem of tourism in Uzbekistan. european Journal of Research and Reflection in Educational Sciences EJRRES Vol.7 №12. 2019.220-223 $P$.

8. Yakhshieva Z.Sh. Functioning of Tourist lexis in the discursive space. Journal of Critical Reviews. Vol.7. Issue 5.2020.463$465 \mathrm{P}$.

9. Yakhshieva Z.Sh. a set of terms as the principles of their ordering and description. EPRA International Journal of Research and Development (IJRD). Volume: 5, Issue: 2 February 2020.374-376 P.

10. Yakhshieva Z.Sh., Yakhshieva M.Sh. Progressing Comforts in the Jizzakh region of Uzbekistan. Young Scientist. 2015.45-50 R. (USA)

11. Yakhshieva Z.Sh., Yakhshieva M.Sh. Development of scientific outlook of the students International Scientific Review 2016. No. 4 (14) Boston. USA. 7-8 April 2016.178-179 P.

12. Yakhshieva Z., Babadjanova G. Ibragimova D. Linguoculturology as a Scientific discipline Modern Scientific Challenges and Trends. Collection of scientific works of the International scientific conference. Issue 9. Warsaw 2018. 60-62 P.

13. Yakhshieva Z., Ochilov A., Isanova V.linguistic and Lexicographic Features of Touristic Vocabulary in Uzbek and English Languages

14. International Journal of Research. Vol.5. Issue 18. New Delhi 2018.28-29th June. 72$77 \mathrm{P}$.

15. Siddiqov, R. B. (2015). TRADITIONS AND INNOVATIONS OF ISLAMIC EDUCATION IN INDEPENDENT UZBEKISTAN. Islam in the modern world, 11(4), 241-248. 


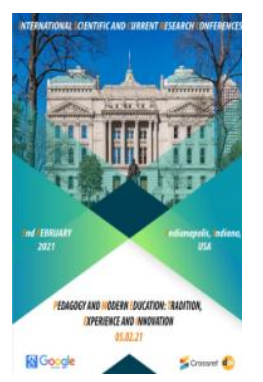

\title{
Developing Students' Multicultural Competencies Through Extracurricular Economic Education
}

\author{
G.A. Sharipova \\ Teacher At School Number 156 Tashkent, Yashnabad District, Uzbekistan
}

\section{ABSTRACT}

This article focuses on the development of cross-cultural competencies through economic education for students in extracurricular activities in mathematics.

\section{KEYWORDS}

Extracurricular activities, economic education, general cultural competencies, case study, group work, pair work.

\section{INTRODUCTION}

Living in a society based on today's market economy requires people, especially young people, to have a broad knowledge of economics. Therefore, one of the urgent tasks of today's educators is to organize extracurricular activities in mathematics in order to equip them with economic knowledge from an early age, and to provide economic education to students through these activities.

Economic education is one of the components of intercultural competence, which develops in students the ability to think about thrift, diligence, initiative, entrepreneurship, economic calculations. At the same time, it teaches students to appreciate our historical, natural, material and spiritual heritage.

The content of economic education has been constantly enriched by Eastern thinkers. In particular, Al-Khwarizmi emphasizes the importance of mathematics in human life. According to him, one should know the science of arithmetic and be diligent in one's work. Then he can measure the results of his work (and those of others) through measurements.

Abu Nasr al-Farabi, in his book On Achieving Happiness, writes: "One should know how to spend one's money wisely. Spending money and being jealous lead to 
greed. The unplanned use of money leads to recklessness"[1]

From the above, it can be seen that economic education of students has always been one of the most pressing issues.

In math classes, we focus on developing students' applied mathematical skills through examples and exercises that illustrate the practical application of these concepts to the subject, mastering the basic concepts of mathematics. Through information on the application of mathematics in nature, production, and various areas of human life, we try to teach students to solve life problems mainly through extracurricular activities.

In particular, we provide students with economic education by teaching them to solve economic problems in extracurricular activities, in order to "revive" abstract information from mathematics in the organization of this process, to provide students with interesting information and assignments with their active participation. We have established. The following is a classification of a class activity with 5 th graders called "Saving and Math in the Family". in the Family

Course Title: Saving and Mathematics

Course Objectives:

Learning Objective: To teach students to solve economic problems.

Educational purpose of the lesson: To teach students to be thrifty, business-minded, enterprising in everyday life and in the family through economic education.

Developmental Objective: To develop students' ability to think about economic calculations by solving problems.

\section{Basic competencies:}

National and cultural competencies: Explains the invaluable role of mathematics in the appreciation of national, spiritual, and cultural heritage, the rational use and conservation of natural and material resources.

Competences in science: To be able to apply the learned mathematical knowledge in the learning process and in everyday life.

Type of training: Strengthening the knowledge and skills learned

Teaching methods: Case study, brainstorming, group work, pair work.

Equipment used in the lesson: computer, projector, handouts.

\section{Course:}

I. Organizational part: Students' readiness for the club is checked, the attendance is listened to and the club's journal is continued.

II. Homework Review and Reinforcement: Homework is reviewed and discussed with students. Students will then be asked the following questions:

-Dear students, what do you mean by saving in the family? frugal?

- Is it good or bad for people to be

- How do we do mathematical calculations in the family?

The students' answers to the above questions will be listened to and discussed with the circle members.

-Dear students, today's new topic is "Saving in the family and math." Today we are 
going to discuss with you the benefits of saving money in our family and daily life by solving problems. Are you ready for today's lesson?

-"Yes, of course, Master!"

- Then we started today's training!

III. Description of the new topic:
The participants of the circle are divided into two groups. The following case assignments are then given through handouts to develop students 'ability to think about economic calculations by teaching them how to use our natural resources wisely. (See Table 1)

\section{Table 1}

\begin{tabular}{|c|c|}
\hline Case assignments for group 1 & Case assignments for group 2 \\
\hline $\begin{array}{l}\text { Unnecessary burning in the apartment for } 50 \\
\text { hours a month: } \\
\text { a) one } \\
\text { b) two } \\
\text { c) three } \\
\text { How much is the extra charge for an electric } \\
\text { light bulb? (Assume that the cost of } 1 \text { kilowatt- } \\
\text { hour of electricity is } 295 \text { soums) }\end{array}$ & $\begin{array}{l}\text { According to economists, if the tap is not } \\
\text { properly closed, it will leak } 140 \text { liters of water a } \\
\text { day. If the cost of } 1 \text { cubic meter of cold water is } \\
766 \text { soms: } \\
\text { a) How much water is wasted from this } \\
\text { unadjusted faucet in a month ( } 30 \text { days)? } \\
\text { b) How much should be paid for wasted } \\
\text { water? }\end{array}$ \\
\hline
\end{tabular}

The above case assignments will be discussed and resolved by the team members. One student from each group then draws the completed case assignments on the board and explains the problemsolving process.

Students will then be asked the following questions:

-Dear students, $5 \mathrm{~kg}$ of candy was bought for 38000 soums per kilogram. How much does it cost in total [2]?

-To do this, you need to pay $38000=5=190000$ soums.

-Congratulations dear students! So, if we denote the total amount of money paid by C, the price of the commodity by $p$, and the quantity by $n$, the relationship between these quantities can be written by the following formula:

$$
\mathrm{C}=\mathrm{p} \cdot \mathrm{n}(\mathbf{1})
$$


(1) In a case based on a formula, who can tell the formula for finding the price of a commodity?

- To find the price of a commodity, the total amount paid must be divided by the quantity of the commodity

$$
\mathrm{p}=\mathrm{C}: \mathbf{n}(2)
$$

- Dear students! (1) Who can derive the formula for finding the quantity of a commodity in the case based on a formula?

- To find the quantity of the goods, the total amount paid must be divided by the price of the goods:

$$
\mathbf{n}=\mathbf{C}: \mathbf{p}(3)
$$

The answers given by the students are written by the teacher one by one on the board. The students are then asked to work in pairs:

Problem1: A total of 78000 soums was paid for $13 \mathrm{~kg}$ of apples. Find the price of apples. Solution: We replace the letters in the formula $p=C: n$ with certain values given in the problem. As a result, we obtain the equation $p=78000: 13$. Solve it and find that $p=6000$ soums.

Answer. 6000 soums.

Students are encouraged to write the terms and conditions of the problem as follows:

Given:

$\mathrm{n}=13 \mathrm{~kg}$

$C=78000$

$p=?$
Solution:

$$
\mathrm{p}=\mathrm{C}: \mathrm{n}
$$$$
p=78 \text { 000: } 13
$$$$
\mathrm{n}=6000 \text { soums }
$$

Answer. 6000 soums.

IV. Consolidation of a new topic: Then the following problems are solved on the board together with students. The conditions for submitting the questions are shown on the slides:

Problem2: How many meters of wallpaper will the room need [3]? 


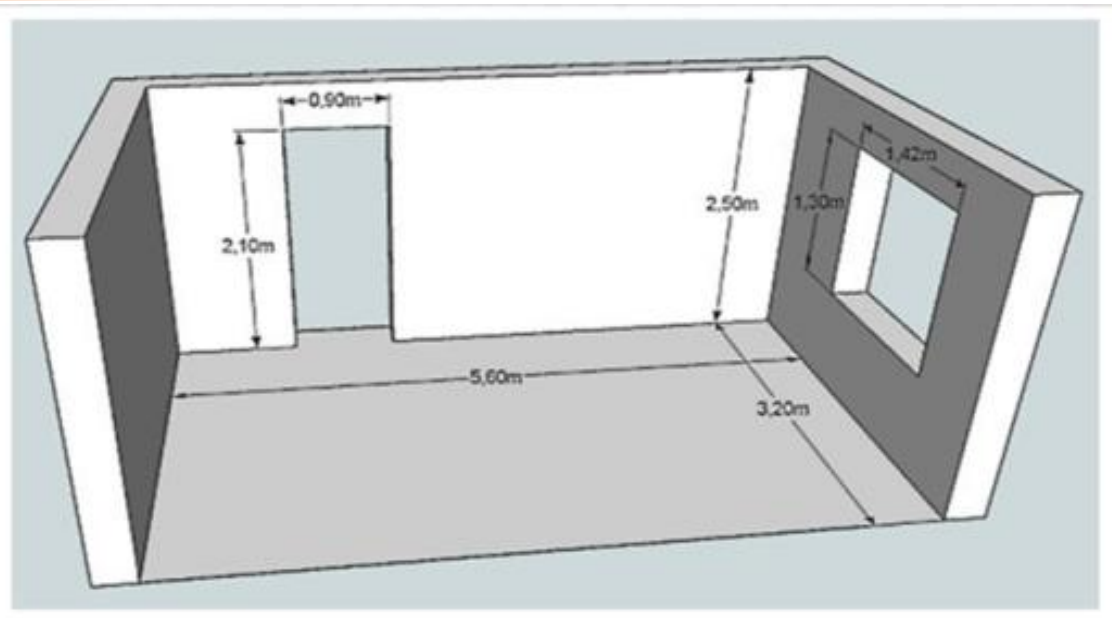

The following 4 questions are then given to students to work in pairs, and 5 questions are given to students to work in groups:

Problem3: An advertising event is being held in the store. A third will be gifted to both purchased soap packs. The price of a pack of soap is 6000 soums. How many packs of soap can you get for no more than 75000 soums.

Problem 4: You will need 200 grams of paint to paint 1 square meter of floor. The paint is sold in $3-k g$ jars. How many cans of paint do you need to buy to paint a floor that is 60 square feet in size? If the price of a can of paint is 60000 soums, how much money will be needed for painting?

V. Concluding Session: At the end of the session, students will have a short interview. They are asked the following questions:

- Did you like our student club today?

- What is the role of mathematics in our daily lives?

- What conclusions did you draw from today's lesson?

VI. Homework Assessment and Assessment: Students are asked to create and solve at least two economic problems as homework. Students who actively participate in the club will be recognized and encouraged.

\section{CONCLUSION}

In conclusion, by providing economic education to students in extracurricular activities in mathematics, it is possible to achieve the development of intercultural competencies such as thrift, business, thinking about economic calculations. 
PEDAGOGY AND MODERN EDUCATION: TRADITION, EXPERIENCE

AND INNOVATION - INTERNATIONAL CONFERENCE

Published: February 05, 2021 | Pages: 82-87

\section{REFERENCES}

1. O'.Zubaydullayev. Pedagogical bases of preparing students for economic education of primary school students. Samarkand-2013

2. B.Q.Haydarov. Mathematics 5th grade textbook. Part 1. Tashkent-2020. -p. 111

3. B.Q.Haydarov. modern approaches to teaching mathematics. Tashkent-2019. - p.125 


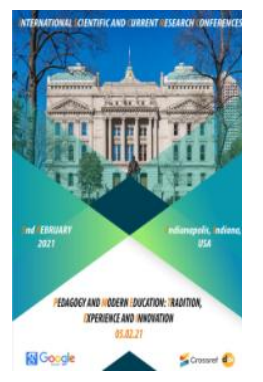

\section{Voice Functional Impairments In Children And Adolescents}

D. Rajabov

Tashkent Medical Academy Tashkent, Uzbekistan

J.A. Djuraev

Tashkent Medical Academy Tashkent, Uzbekistan

\section{ABSTRACT}

The problem of early diagnosis and timely correction of voice disorders is socially and economically significant, since the voice-speech professions in modern society are becoming more widespread. Many pathological conditions leading to impaired vocal function develop in childhood and adolescence. The pathology of the voice in a child progresses gradually and is usually not accompanied by a violation of general well-being. This explains the often inattention of parents, pediatricians and pediatric otorhinolaryngologists to the voice problem. The lack of primary screening of voice disorders in children leads to a significant prevalence of pathology, according to various literary sources constituting up to $40 \%$ or more and having a tendency to increase. The problem of the existing voice disorder becomes relevant when a young person chooses a future profession, when, according to the state of the voice function, an applicant may be recognized as unfit or partially fit for the chosen type of professional activity. Therefore, the timely detection and treatment of voice disorders in childhood is relevant.

\section{KEYWORDS}

Voice disorders, voice leading, dysphonia, vocal cord nodules.

\section{INTRODUCTION}

The purpose and objectives of the study: analysis of the pathology of the vocal apparatus in children, adolescents and students mastering the voice-speech profession.
The analysis of the pathology of the vocal apparatus was carried out according to the data on the number of visits to the phoniatrist of the otorhinolaryngology polyclinic of the multidisciplinary clinic for TMA. 
According to our data, as well as according to the literature, the most common pathology of the vocal apparatus in childhood is nodules of the vocal folds, the so-called "screamer's nodules" or "calluses". Taking into account the insufficient alertness of doctors and parents, nodules of the vocal folds in children are a chronic disease that requires long-term drug treatment and, without fail, phonopedic correction, since without changing the manner of voice-leading, conservative treatment of this pathology is not effective. Surgical treatment of vocal fold nodules in children, given the anatomical and physiological characteristics of the children's larynx, is extremely rare. Next in frequency of occurrence are acute and chronic inflammatory diseases of the larynx, often associated with chronic pathology of the nose, nasopharynx, pharynx. An important role in the development of laryngeal pathology is played by the postnasal leakage syndrome, due to the constant infection of the larynx with sputum, as well as the tension of the vocal folds with its frequent coughing. An increase in the proportion of functional disorders of the voice (dysphonia and aphonia), as well as mutational dysphonia, is observed in older children and adolescents, when the influence of the functional state of the nervous and endocrine systems of a growing patient on the vocal apparatus increases.

The increase in the number of voice pathologies is facilitated by the increase in daily emotional and vocal load associated with increased neurotization of the child population, as well as the wide development and popularity of the network of children's state and private musical and theatrical groups. Neglect of the principles of protection and hygiene of the voice in childhood, the long-standing vicious mechanism of voice formation in a child subsequently leads to the formation of persistent and irreversible functional and organic diseases of the vocal apparatus.

\section{CONCLUSION}

As a result, according to our observations, professions associated with voice tension are sometimes obtained by persons whose the vocal apparatus is obviously not adapted to large voice loads, that is, initially having contraindications to them. Violations of the voice function in childhood are quite common, which is associated with inadequacy and imperfection of primary screening. The most common pathology of the vocal apparatus in childhood - nodules of the vocal folds, is usually detected quite late and requires longterm treatment and phonopedic correction. Diagnosis of laryngeal pathology in children is difficult due to age characteristics. The attention and alertness of adults who are with the child (parents, teachers, doctors) to the problem of protecting the child's voice will reduce the prevalence of chronic forms of dysphonia in children and will contribute to the prevention of voice disorders in adults, including those of voice-speech professions.

\section{REFERENCES}

1. Botirov A. J. et al. Clinical and morphological results of xenografts to use in myringoplasty //The International Tinnitus Journal. - 2020. - T. 24. - №. 1. - pp. 1-6.

2. Djuraev J. A. et al. Results of Allergological and Immunological Research in Patients with Polipoid Rhinosinusitis //Asian Journal of Immunology. - 2020. - pp. 34-40.

3. Djuraev J. A., Khasanov U. S., Vokhidov $\mathrm{U}$. N. The prevalence of chronic inflammatory diseases of the nose and paranasal sinuses in patients with myocarditis //European Science Review. - 2018. - №. 5-6. - pp. 147-149.

4. Djuraev J. A. et al. Results of an immunogistochemical study in patients with polipoid rhinosinusitis //European Journal of Molecular \& 
Published: February 05, 2021 | Pages: 88-90

Clinical Medicine. - 2020. - T. 7. - №. 2.

- pp. 2526-2541.

5. Khasanov U. S., Djuraev J. A. Morphological characteristics of chronic polypous rhinosinusitis //Cutting edge-science. - 2020. - pp. 30.

6. Narmurotov B. K., Boymuradov S. A., Djuraev J. A. Comparative Characteristics of Rheological Properties Of Blood In Combined Face Injuries Before And After Treatment //The American Journal of Medical Sciences and Pharmaceutical Research. - 2021. - T. 3. - №. 01. - C. 67-75.

7. Shaumarov A. Z. et al. Role of Hemostatic Agents in Simultaneous Surgical Interventions in the Nasal Cavity.

8. Kurbonov Y. K., Boymuradov S. A., Djuraev J. A. Purulent-Necrotic Diseases of The Face: Aspects of Diagnostics And Treatment //The American Journal of Medical Sciences and Pharmaceutical Research. - 2021. - T. 3. - №. 01. - C. 24-30.

9. Nigmatov I. O. et al. Post-Traumatic Defects And Face Deformations: Features of Diagnostics And Treatment //The American Journal of Medical Sciences and Pharmaceutical Research. - 2021. - T. 3. - №. 01. - C. 55-66.

10. Jumanov D. A. U. et al. International Journal of Biological and Pharmaceutical Sciences Archive //International Journal of Biological and Pharmaceutical Sciences Archive. - 2020. - T. 1. - №. 1. - C. 011-015.

11. VOHIDOV U. N. et al. Current issues of the treatment of chronic polypous rhinosinusitis //Journal of Biomedicine and Practice. - 2020. - T. 2. - №. 5.

12. Khasanov U. S., Vokhidov U. N., Djuraev J. A. State of the nasal cavity in chronic inflammatory diseases of the nose and paranasal sinuses in patients with myocarditis //European science,(9 (41)).-2018. - 2018.

13. Salakhova, E. Z., \& Shamsitdinova, $M$. G. (2020). ADVANCED PEDOGOGICAL TECHNOLOGIES IN EDUCATION IN THE 21-ST CENTURY. Theoretical \& Applied Science, (5), 743-746.

14. Vohidov U. N. Djuraev JA ugli, Makhsitaliev, MI, \& Khamidjanov, s. O.(2020). Current issues of the treatment of chronic polypous rhinosinusitis //Journal of Biomedicine and Practice. - T. 2. - №. 5 .

15. Makhsitaliev $M$. et al. The Functional State Of The Mucous Membrane of The Nasal Cavity And Paranasal Sinuses After Radical And Minimally Invasive Surgical Interventions //The American Journal of Medical Sciences and Pharmaceutical Research. - 2021. - T. 3. - №. 01. - C. 31-40.

16. Давлатова, Р. Х. (2020). ПРОСТРАНСТВЕННЫЙ ДЕЙКСИС И ЕДИНИЦЫ ЕГО ВЫРАЖЕНИЯ В УЗБЕКСКОМ ЯЗЫКЕ. In Colloquiumjournal (No. 6-5, pp. 37-39). Голопристанський міськрайонний центр зайнятості= Голопристанский районный центр занятости.

17. Shamsitdinova, M. (2021). Difficulties In Teaching Law Students Listening Comprehension In English Language Teaching. The American Journal of Political Science Law and Criminology, 3(01), 1-8. 


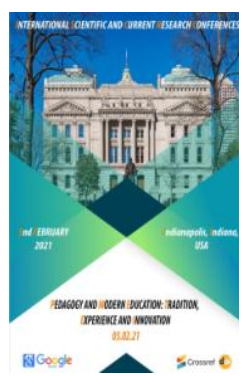

Adenoiditis: A Modern Look In Diagnostics And Treatment

J.Kh. Razzokov

Department Of Otolaryngology And Dentistry Tashkent Medical Academy

Tashkent, Uzbekistan

J.A. Djuraev

Department Of Otolaryngology And Dentistry Tashkent Medical Academy

Tashkent, Uzbekistan

\section{ABSTRACT}

Most of the visits of parents with children to an otorhinolaryngologist are associated with frequently recurring, protracted and chronic diseases of the ENT organs. The most common complaints are a runny nose, difficulty breathing through the nose, and a cough that does not go away for a long time and is often repeated. Some patients have complications of the common cold: sinusitis, recurrent acute catarrhal, less often purulent otitis media, tubo otitis, secretory otitis media with signs of hearing loss, exacerbation of chronic purulent otitis media, tracheitis, bronchitis, stenosing laryngotracheitis. Failure to treat ENT pathologies, short intervals between diseases, frequent acute respiratory infections are also a reason for consulting an ENT doctor. When interviewing parents, it was found that rhinopharyngitis, allergic rhinitis, and adenoiditis are most often diagnosed. For a clearer understanding of the nature and methods of treatment of these diseases, it is necessary to characterize those pathological changes that are observed in the upper respiratory tract, i.e., in the nasal cavity, nasopharynx and pharynx.

\section{KEYWORDS}

Upper respiratory tract infections, adenoiditis, etiology, diagnosis, clinical picture, treatment, children.

\section{INTRODUCTION}

The aim of the study was - increasing the effectiveness of treatment of chronic adenoiditis in frequently ill children by developing a therapeutic and diagnostic algorithm using endoscopic and functional monitoring.

\section{MATERIAL AND RESEARCH METHODS}

In accordance with the purpose of the study and to fulfill the assigned tasks, clinical studies will be carried out in patients with adenoiditis in 50 children who are often ill who were examined and treated at the ENT department 
of the multidisciplinary clinic of the Tashkent Medical Academy in 2020-2023. All patients with adenoiditis are planned to undergo examination methods, including clinical, functional research methods of the nasopharynx and X-ray examination. The data obtained in the course of the research will be processed using Microsoft Excel 10.0 software; Statistica 10.0 using Student's t test.

\section{SCIENTIFIC NOVELTY OF RESEARCH}

For the first time, a comprehensive examination of frequently ill children with chronic adenoiditis was carried out, including clinical, microbiological, serological, molecular biological, instrumental (endoscopy, tympanometry) and functional methods (ECG and recording of the peak expiratory flow rate) studies, which made it possible to obtain new data on the frequency of infection with herpes viruses and atypical flora. The features of the course of the disease, the development of complications, depending on the presence and absence of infection with herpes viruses and / or intracellular pathogens, were identified, as well as the structure of infection was determined. It was proved for the first time that in chronic adenoiditis in frequently ill children, the development of functional disorders of the bronchopulmonary system in the form of a decrease in the peak expiratory flow rate is facilitated by the presence of atypical pathogens (chlamydia and mycoplasma). For the first time, a scheme for the diagnosis and selection of the optimal method for the treatment of chronic adenoiditis in frequently ill children has been developed, as well as new data have been obtained on the most effective combination therapy (antiviral and / or antibacterial therapy followed by adenotomy).

\section{PRACTICAL SIGNIFICANCE}

The data obtained in the course of the study can be used in the practice of an otorhinolaryngologist to determine the diagnostic strategy and choose tactics for managing patients with the pathology under consideration.

\section{REFERENCES}

1. Botirov A. J. et al. Clinical and morphological results of xenografts to use in myringoplasty //The International Tinnitus Journal. - 2020. - T. 24. - №. 1. C. 1-6.

2. Djuraev J. A. et al. Results of Allergological and Immunological Research in Patients with Polipoid Rhinosinusitis //Asian Journal of Immunology. - 2020. - C. 34-40.

3. Djuraev J. A., Khasanov U. S., Vokhidov U. $\mathrm{N}$. The prevalence of chronic inflammatory diseases of the nose and paranasal sinuses in patients with myocarditis //European Science Review. 2018. - №. 5-6. - C. 147-149.

4. Djuraev J. A. et al. Results of an immunogistochemical study in patients with polipoid rhinosinusitis //European Journal of Molecular \& Clinical Medicine. - 2020. - T. 7. - №. 2. - C. 2526-2541.

5. Khasanov U. S., Djuraev J. A. Morphological characteristics of chronic polypous rhinosinusitis //Cutting edgescience. - 2020. - C. 30.

6. Narmurotov B. K., Boymuradov S. A., Djuraev J. A. Comparative Characteristics Of Rheological Properties Of Blood In Combined Face Injuries Before And After Treatment //The American Journal of Medical Sciences and Pharmaceutical Research. - 2021. - T. 3. - №. 01. - C. 6775.

7. Shaumarov A. Z. et al. Role of Hemostatic Agents in Simultaneous Surgical Interventions in the Nasal Cavity.

8. Kurbonov Y. K., Boymuradov S. A., Djuraev J. A. Purulent-Necrotic Diseases Of The Face: Aspects Of Diagnostics And Treatment //The American Journal of Medical Sciences and Pharmaceutical 
Research. - 2021. - T. 3. - №. 01. - C. 2430.

9. Nigmatov I. O. et al. Post-Traumatic Defects And Face Deformations: Features Of Diagnostics And Treatment //The American Journal of Medical Sciences and Pharmaceutical Research. - 2021. - T. 3. №. 01. - C. 55-66.

10. Jumanov D. A. U. et al. International Journal of Biological and Pharmaceutical Sciences Archive //International Journal of Biological and Pharmaceutical Sciences Archive. - 2020. - T. 1. - №. 1. - C. 011-015.

11. VOHIDOV U. N. et al. Current issues of the treatment of chronic polypous rhinosinusitis //Journal of Biomedicine and Practice. - 2020. - T. 2. - №. 5.

12. Khasanov U. S., Vokhidov U. N., Djuraev J. A. State of the nasal cavity in chronic inflammatory diseases of the nose and paranasal sinuses in patients with myocarditis //European science,(9 (41)).2018. - 2018.

13. Vohidov U. N. Djuraev JA ugli, Makhsitaliev, MI, \& Khamidjanov, s. O.(2020). Current issues of the treatment of chronic polypous rhinosinusitis //Journal of Biomedicine and Practice. - T. 2. - №. 5 .

14. Salakhova, E. Z., \& Shamsitdinova, M. G. (2020). ADVANCED PEDOGOGICAL TECHNOLOGIES IN EDUCATION IN THE 21ST CENTURY. Theoretical \& Applied Science, (5), 743-746.

15. Makhsitaliev $M$. et al. The Functional State Of The Mucous Membrane Of The Nasal Cavity And Paranasal Sinuses After Radical And Minimally Invasive Surgical Interventions //The American Journal of Medical Sciences and Pharmaceutical Research. - 2021. - T. 3. - №. 01. - C. 3140. 


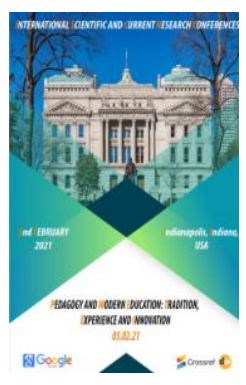

\title{
Central Bukantov Mineral Associations Of Gold Mining And Their Composition (On The Example Of Kaskirtov, Boztov, Jelsay Fields)
}

\author{
Marufjon Shodmonovich Moyliev \\ Phd Student, National University Of Uzbekistan Named After Mirzo Ulugbek, \\ Tashkent, Uzbekistan \\ Husniddin Akrom Ogli Boboyorov \\ Lecturer Faculty Of Geology And Geoinformation Systems National University Of Uzbekistan \\ Named After Mirzo Ulugbek, Uzbekistan
}

\begin{abstract}
This article investigates the mineral composition of endogenous gold ores in the regions northwest of Central Bukantov and the associations formed by them. According to the results, the endogenous ore consists mainly of pyrite, rare chalcopyrite, arsenopyrite, galenite, sphalerite and a small amount of sulfosols and silver. These minerals have formed mineralized mineralization in metamorphic rocks, mineral paragenic associations in the pyrite-arsenopyrite, polysulfide-silver-sulfosol gold series.
\end{abstract}

\section{KEYWORDS}

Central Bukantov, Kaskirtov, Boztov, Jelsay, gold, mineral associations, paragenic associations.

\section{INTRODUCTION}

An in-depth research of the mineralogical and paragenetic aspects of gold mining makes it possible to determine the formation and distribution of gold, as well as the physicochemical conditions of gold mining and the processes of ore formation $[1,3]$.

The studied area is geologically related to the South-Bukantov structural-formation zone, which is part of the Oloy-Kokshal structuralfacies zone of the Southern Tien-Shan, from the Okjetpes Mountains in the south to the Kaskirtov Mountains in the northwest [2].
To determine the possibility of using mineralogical data in predicting gold ores, the main minerals were studied using microprobe analysis (Superprobe JXA-8800R (Jeol, Japan)). The reason for the application of this method is the microminerality of the minerals studied in the main part of the research area according to the forms of location.

\section{RESULTS}

The primary mineralized ores in these areas consist mainly of pyrite, rare chalcopyrite, arsenopyrite, galena, sphalerite and a small 
PEDAGOGY AND MODERN EDUCATION: TRADITION, EXPERIENCE AND INNOVATION - INTERNATIONAL CONFERENCE

Published: February 05, 2021 | Pages: 94-96

amount of sulfosols, as well as silver and other minerals.

The rocks that make up the rock are quartz, albite, sericite, chlorite, kaolinite and carbonates.

Endogenous mineralization in the field formed mineral paragenic associations in the following sequence:

- Mineralization of minerals in metamorphic rocks;

- Pyrite-arsenopyrite

- polysulfide-silver-sulfosol.

Mineral minerals of metamorphic rocks are pyrite (pyrite-1), which is found in fine-grained form in the surrounding rocks. In metaevolites and sandstones, pyrite, formed in the form of grains of almost equally sparse isometric shape, is bounded by uneven surfaces. In quartz-mica shales, pyrite sometimes forms flattened grains between layers of rock, the particle size of which varies from $0.00 \mathrm{~nm}$ to $1.5 \mathrm{~mm}$. Sparse pyrite particles, their additives, and many aggregates cause irregularly shaped separations. The texture is hollow, the structure is hypidiomorphic.

The main mass of ore mineralization is associated with altered zones and quartzified rocks under the influence of hydrothermal processes. Such sulfide mineralization is often distributed in the zones of pre-mining change or in the periphery of the quartzation zones. They form cellular, lens-like clusters of different shapes in chlorinated rocks and in quartzation zones in different directions, sometimes between layers of rocks.

In some cases it can be observed that the pyrite, which accumulates in the form of cells and metazars, is located as a thin line in the cracks in the quartz veins, which is clearly visible in the fractured fragments along the crack. The location of the crystals in this state indicates that during the sulfidation process, pyrite passes through the zone of quartz metamorphic rocks and is formed between their layers. Sulfides consist mainly of pyrite, partly of chalcopyrite and arsenopyrite.

The pyrite-arsenopyrite paragen mineral association consists of pyrite-2 and arsenopyrite-1. The intensity of this association determines the industrial value of the ores. Pyrite, which is greater than arsenopyrite in terms of its quantitative ratio, is the main carrier of dispersed gold. Gold, the main important component of gold-sulfide ores in the research areas, occurs as a mixture in the composition of sulfide minerals in the endogenous and oxidized ore zones, as well as in pure form [2]. In ore bodies, this association has been shown to interact with rapidly serrated, quartzized, and chlorinated zone rocks (birch-listvenite metasomatites).

Pyrite-2 often forms irregularly shaped metacrystals with a diameter of $0.15-0.5 \mathrm{~mm}$. In the quartzated and altered zones of the rocks, their size ranged from 0.1 to $1.5 \mathrm{~mm}$, forming strata, cells, lenses, and veins. It is more chain-like, spotted, cellular, clustered, and xenomorphic-grained, and is sometimes observed in the form of separate cubic, pentagondodecahedral-shaped crystalline fragments. They are differently distributed in the quartz composition. Pyrite crystals formed more dense clusters, and they often have a chain-like property. This cluster of crystals is located at the contact of quartz and layered rocks.

The pyrite-2 association showed long arsenopyrite and the rare chalcopyrite-1. In this case, pyrite formed large (1-2 mm) isometric crystalline grains, arsenopyrite needle-shaped, prism-shaped, rhombic aggregates, chalcopyrite formed irregularly shaped separations near and in the composition of pyrite.

The polysulfide-silver-sulfosol association consists of quartz-carbonate cross-sections 
containing pyrite-3-sphalerite-chalcopyrite finely oriented in different directions. They contain arsenopyrite-2, micro-marcasite extracts, chalcopyrite, chalcocite, bornite, sphalerite and rare galinate. This association includes sulfide silver-acanthite, bleklaya ore, and pure gold.

Pure gold has a plate-like morphology and measures up to $0.4 \mathrm{~mm}$ in length. It is brighter than pyrite and brighter than chalcopyrite found here. Gold has a clearly visible yellow color, with no sulfides grown in association with it. The sulfides in the rocks are not oxidized, so in these rocks the gold is primary and is associated with changes in the rocks under the influence of metasomatic processes. According to the interaction of paragenic minerals, it can be noted that paragenesis was formed after gold pyrite-1 (metamorphogenic) and with a more quartzation zone, which was simultaneously intersected with quartz-pyrite-3-chlorite.

\section{CONCLUSION}

This article investigates the mineral composition of endogenous gold ores in the regions northwest of Central Bukantov and the associations formed by them. According to the results, the endogenous ore consists mainly of pyrite, rare chalcopyrite, arsenopyrite, galenite, sphalerite and a small amount of sulfosols and silver. These minerals have formed mineralized mineralization in metamorphic rocks, mineral paragenic associations in the pyrite-arsenopyrite, polysulfide-silver-sulfosol gold series. Pyritearsenopyrite is the major carrier of pyrite dispersed gold in the paragenic mineral association.

\section{REFERENCES}

1. Kremenetsky A.A., Mintser E.F. The universality of gold ore systems is a key criterion for the regional forecast of industrial mineralization // Domestic geology. 1995. № 1. - pp. 19-27.

2. Karabaev M.S.Typomorphic features of the main minerals of gold mineralization of the Karabugut area of the Auminzatau mountains (Central Kyzylkum) and their significance for forecasting // Mining and geological journal Republic of Kazakhstan. 2015, №3-4. -pp.55-59.

3. Ore formations and main features of gold metallogeny in Uzbekistan. Tashkent: Science, 1969. -p.395. 


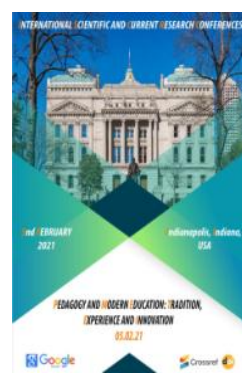

\title{
A New Worldview In Alisher Navoi's Commentary
}

\author{
Sapura Mustafakulovna Nematova \\ Lecturer Faculty Of Uzbek Language And Literature Jizzakh State Pedagogical Institute, \\ Uzbekistan
}

\section{ABSTRACT}

This thesis reflects the originality and new worldview of Alisher Navoi's Majolis un-nafois.

\section{KEYWORDS}

Tazkira psyche lyrical emotion interpretation worldview

\section{INTRODUCTION}

It is worth reading and studying the golden works of Hazrat Mir Alisher Navoi, the sultan of poetry, a unique talent, who made a worthy contribution to the Uzbek classical literature with his work. it is both a debt and an obligation for one of us. His name and legacy are immortal as the name and legacy of such great word artists as Homer and Dante, Rudaki and Ferdowsi, Nizami and Shota Rustaveli, Saadi and Jami, Shakespeare and Balzac, Pushkin and Tolstoy, Rabindranath Tagore and Lou Sin (1:38).

Navoi devoted all his activity and creativity to the struggle for human happiness, peace of the people, beautification, development of science, art and literature. The poet said, "I hope that my career will not go downhill, and that the triumph of my writings will not be to the liking of the earth" (2:341).

It is known that Alisher Navoi followed the cultural life of the whole country and did his best to develop literature and science, art and creative work in general. In this sense, his commentary on Majolis un-nafois is of special significance. Navoi first compiled the Majolis un-nafois in 1491. As noted by Suyima Ganieva, the author of the scientific-critical text of the Majolis un-nafois, he made many innovations and additions to the Majolis un-nafois, and in 1497-1498 his second, revised created a copy. Eliminated some biographical inaccuracies. Majolis un-nafois was a new and very valuable work in tazkirism and became the basis of Uzbek tazkirism (3: 542). 
PEDAGOGY AND MODERN EDUCATION: TRADITION, EXPERIENCE AND INNOVATION - INTERNATIONAL CONFERENCE

Published: February 05, 2021 | Pages: 97-98

\section{THE MAIN FINDINGS AND RESULTS}

Navoi aims to pass on the names and literary works of his contemporaries to future generations, to perpetuate their memory, and to create the first tazkira in his native language.There was a great need and necessity for the emergence of a new tazkira, such as Majolis un-nafois. The development of the Uzbek literary language required not only the creation of works of art in this language, but also the creation of scientific works, including literary works. It was on the basis of these needs that Alisher Navoi's scientific and philological heritage, the Majolis un-nafois, was born. Pre-Majolis un-nafois were written in Persian-Tajik and were dedicated to the representatives of this literature. The development of Uzbek classical literature in the 15th century required that it be mentioned and given a worthy place in many commentaries, such as Amir, Yaqini, Atoi, Sakkoki, and finally Lutfi. Navoi complied with this demand in the Majolis un-nafois. (4:321)

Alisher Navoi's tazkira "Majolis un-nafois", the incomparable artist and great patron of the poetic people, is the basis of Uzbek tazkira, and to this day it has not lost its value. The poet's book contains valuable and instructive words that are intended to be passed not only to his contemporaries, but also to future generations. In the eloquent language of Humamiddin's son Khandamir, he said: " This holy book describes some of the qualities and conditions of many of the scholars and poets who have adorned and adorned the earth with their vivid bodies since the reign of Hazrat Haqqan Shahrukh Mirza "(5: 287).

\section{CONCLUSION}

In conclusion, it is clear from these notes that Navoi's work has had a great positive impact on the development of Uzbek literature and culture over the centuries.

\section{REFERENCES}

1. Mallayev N. History of Uzbek literature. T., 1976. -P 349.

2. AlisherNavoiy. Works. 15 volumes. Volume 13 Majolis un nafois. -Tashkent: Fan, 1997.

3. Oybek. About Majolis un nafois. Tashkent, 1979

4. Hayitmetov A. About a unique edition of "Majlis-un nafois" // Uzbek language and literature. -T .: Fan, 2004. №2.

5. BorovkovA.K. Madjalisan-nafais (sobranieredkosnyx.

Otdelenieliteraturyiyazyka, 1927. Tom 6).

6. Akhmedova, S. (2021). Philosophy In" Why Me" By Omon Matjon's Epic. The American Journal of Social Science and Education Innovations, 3(01), 100-104.

7. Saydiyevna, A. S. (2020). OMON MATJONNING “QUSH TILI” DOSTONI GENEZISI. Сўз санъати халқаро журнали, 2(3). 


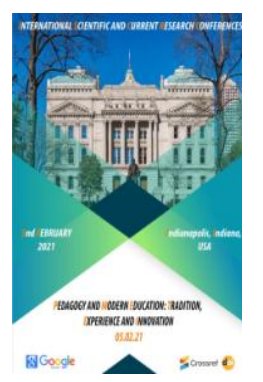

\section{Transformation Of Farhad's Image In The Diwan "Bada'i Al- Bidaya" By Alisher Nava'i}

Kh.Kholmurodov

Researcher Jizzakh State Pedagogical Institute, Uzbekistan

\section{ABSTRACT}

In this article it is discussed about the phenomenon of Farhad's image transformation in Alisher Nava'i's Bada'i al-Bidaya as a unique poetic problem. It examines the peculiarities of the transformation of the image in the poetry of Alisher Nava'i and its artistic and authentic features.

\section{KEYWORDS}

Classical tradition, lyricism, image, transformation, artistic detail, poetic function, literary law, interpretation and analysis

\section{INTRODUCTION}

In epic-lyrical interpretations of Eastern literature, the image of Farhad is an extremely productive poetic symbol. The scope of expression and interpretation of this image in the classical literature of the East is also extremely wide. The process of his transition from oral literature to written creation, from epics to lyrical poetry, from reality to emotion, manifests itself as a very deep and profound poetic phenomenon. In a word, classical literature connects the long historical stages of the art world with the interpretation of the same subject and image. In recent years, the issue of transformation of themes and images, plots and symbols in world philological research has been assessed as a separate poetic phenomenon from a scientific and theoretical point of view. In particular, the transformation of ancient and traditional poetic images, motifs are studied in detail in Russian literature. Transformation is derived from the Latin word "transformatio" (modification), which is used in various senses, in different forms of art. For example, in linguistic dictionaries it is interpreted as "creating a second structure by changing the basic syntactic structure on the basis of the rules of language." The term in Russian means 1) preobrazovanie - change, transformation, transformation, substitution,

2) 
PEDAGOGY AND MODERN EDUCATION: TRADITION, EXPERIENCE AND INNOVATION - INTERNATIONAL CONFERENCE

Published: February 05, 2021 | Pages: 99-101

prevrashchenie - $\quad$ transformation, transformation, transformation, transformation, transformation of a dome into a butterfly, increase or decrease of electric current in physics [5.168]. From this is understood the phenomenon of transformation from one state to another, or from one form to another, change, change from one state to another, change. There is a similar concept of transformational analysis, which is a method of bringing different structures into a simple nuclear structure. In literary criticism, it is understood that a literary event changes from one form to another in a broad sense in terms of form and content, while in a narrow sense, a symbol, image or plot changes in different genres, artistic expressions, acquires different meanings in a particular creative world. One of such symbols effectively used in Alisher Nava'i's poetry is the image of Farhad. The statistics of expression in his poetic lyrical diwans are around three hundred, each with its own meaning and appearance. For example, if we look at the Bada'i al-Bidaya, Alisher Nava'i refers to the image of Farhad fifty times in various artistic, symbolic and structural aspects. At this point, in the classical literature, when it comes to the etymology of the image of Farhad, changes in various formal-genre and semantic expressions, it seems that the transformation of the image is manifested on a very large scale. It is the transformation of Farhad's image from epic interpretations into lyrical expressions, and the changes in this process, the transformation of this image into a stable expression of artistic thought - all through the immortal laws of classical literature. The image of Farhad, described more than 50 times in Alisher Nava'i's lyrical diwan Bada'i alBidaya, creates colorful landscapes in terms of form and structure. For example, Farhad 14, Farhad and Shirin 12, Farhad and Majnun 19, Vomiqu Farkhodu Majnun 3, Vomiqu Farkhod 2, Shirin are mentioned 7 times. It is obvious that in the poet's lyrics the image of Farhad in parallel with the image of Majnun is much more effective. Also, the interpretation in the style of Farhad and Shirin is not large. In Alisher Nava'i's office, the image of Farhad is used alone, along with other symbols and motifs on the theme "Farhad and Shirin". However, in this case, all the symbols serve to convey symbolic meanings.

Besutungakim sutun Farkhod boldi kafi ishq,

\section{THE MAIN FINDINGS AND RESULTS}

He made the pillar "nun" under Besut [BB.47.5]. Apparently, the phenomenon of the transition of Farhad's image to lyricism as an artistic symbol allows other images and symbols related to this theme to move with him, even though they express other symbolic-figurative tones. As a result, different external and internal, external and internal interpretations in the sense of imagesymbol emerge. In particular, Besutun - "this rock is mentioned in legends and myths in connection with the name of Farhad. Farhad is described as a hero who dug a canal at the foot of the mountain and crossed the mountain" [3.97]. Farhad is a perfect image of a creature, which entered the written literature from oral stories and was interpreted at the level of the protagonist as a product of the artistic thinking of Hazrat Alisher Nava'i. Qaf - "the name of the legendary mountain", "the peg that ensures the tranquility of the earth", "the address of the legendary birds such as Simurg, Ango, is the end of the world", "in mysticism the people of Qaf" [2.145]. In poetry, love is not a symbol, but a semiotic point, that is, the center of meaning of the work. Now let's focus on the content of the couplet, then move on to the definition of other symbols. At this point, "Ishq Qafi (Mount of Love), that is, Farhad's pillar (column) for Besutun, made this column" nun "under Besutun." There is a dot at the bottom of the letter "Be" and above the "nun". Accordingly, Farhad is the pillar of love. So, all the images depicted together with Farhad have a symbolism that 
PEDAGOGY AND MODERN EDUCATION: TRADITION, EXPERIENCE AND INNOVATION - INTERNATIONAL CONFERENCE

Published: February 05, 2021 | Pages: 99-101

creates an expression of love. This can also be seen in the parallel lines of Farhad and Shirin.

If he keeps his promise, he will be the mountain of sorrow

I scratched my nails with a razor blade [BB.72.4].

In Alisher Nava'i's lyrical diwan Bada'i albidaya, the interpretation of this couplet in one place does not seem very productive, but when we talk about Farhad, we usually refer to Farhad in the interpretation of Shirin or Shirin, that is, romantic couples are not logically understood in literary texts. For example, in these verses, the lyrical protagonist says, "If he promises Shirinsifat the mistress of the mountain of grief, I will dig him, even if my nails are pierced by Farhad." In this case, the "mountain of sorrow" symbolically refers to the pains in the path of love, such as the Besutun above, the "rhyme of love." No matter how great he is, the lover does not tire of conquering him, and the hardship in this way is the goal for the lover. In conclusion, the image of Farhad in Alisher Nava'i's "Bada'i' al-bidaya" serves to perform a variety of poetic functions. In it, changes in the lyrical expressions of the emblem give rise to various artistic-symbolic meanings. Along with this image, various artistic details, episodic scenes and characters are depicted in parallel.

\section{REFERENCES}

1. Alisher Nava'i. A perfect collection of works. Bada'i al-bidaya. - T .: “Fan”, 1987. 724 pages.

2. Nava'i A. Dictionary. 1 - vol. - Tashkent: Sharq, 2016. -536 pages.

3. Nava'i A. Dictionary. 1 - vol. - Tashkent: Sharq, 2016. - 480 pages.

4. Dictionary of Nava'i works. - Tashkent: G. Gulom Publishing House of Literature and Art, 1972. - 784 pages.
5. Annotated dictionary of the Uzbek language. - T .: "National Encyclopedia of Uzbekistan" State Publishing House, 2006. - 606 pages.

6. Akhmedova, S. (2021). Philosophy In" Why Me" By Omon Matjon's Epic. The American Journal of Social Science and Education Innovations, 3(01), 100-104.

7. Saydiyevna, A. S. (2020). OMON MATJONNING “QUSH TILI" DOSTONI GENEZISI. Сўз санъати халқаро журнали, 2(3).

8. Shamsitdinova, M. (2020). IMPLEMENTATION OF IT AND ICT INTO EDUCATION: MULTIMEDIA TECHNOLOGIES IN CREATING AND USING ELECTRONIC BOOKS. Theoretical \& Applied Science, (11), 5-10.

9. Shamsitdinova, M. (2021). Difficulties In Teaching Law Students Listening Comprehension In English Language Teaching. The American Journal of Political Science Law and Criminology, 3(01), 1-8. 


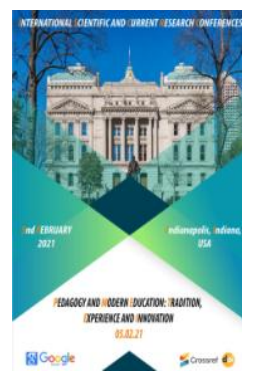

\author{
About A Poem \\ Shohista Saydievna Ahmedova \\ Lecturer Department Of Uzbek Language And Literature Jizzakh State Pedagogical Institute, \\ Uzbekistan
}

\title{
ABSTRACT
}

The role of Babarahim Mashrab's socio-philosophical, religious-mystical and moral views in the cultural and spiritual life of the society is very important. He dedicated himself to the truth and to the people who were the truth. It is known that our world-famous scientists have a wide spirituality, but their fate is difficult. Indeed, "the great names of our great ancestors, the memory of the people and their destiny deserve to continue with dignity" [4, 15].

\section{KEYWORDS}

Bu-Mashrab, Mashrab, Babarahim Mashrab's, Omon Matjon, the hearts of the people

\section{INTRODUCTION}

In particular, Omon Matjon followed in the footsteps of Babarahim Mashrab's predecessors and wrote the poem "BuMashrab, Mashrab", using the ideas they put forward. In this poem, the poet expresses Mashrab's universal qualities in a wonderful way with his worldview.

From the tree of the heavens this morning,

Who scared the black and white birds ?!

Eighteen nights before the summer party,

Who taught the nightingale to sing ?!
Who is he?

This is Mashrab, Mashrab! [2; 68].

\section{THE MAIN FINDINGS AND RESULTS}

The three-celestial tree, the black-and-white birds, and the merry melodies in the verses summarize the main idea that the poet is trying to convey. The celestial tree is like the branches of a tree, the birth of Mashrab, the birth of the successor of mankind. Black and white birds represent the violent officials of the time, while merry melodies are grassy poems written by the poet, a symbol of joy 
and hope in people's hearts. Thus, while the birth of the poet frightened the ravens, it entered the hearts of the common people like a nightingale. Mashrab scholar Momin Hashimkhanov said: "Mashrab lived like a fire, burning and creating like a fire without words. The people sang their sorrows, won the love of the people because of their incomparable talent, and took a deep place in the hearts of the people" (4; 313).

He caught the thief

Who cares about cowardly judges ?!

That's the decent thing to do, and it should end there

Who cares, who cares ?!

Who is he, the wrath of injustice,

This is Mashrab, Mashrab!

In doing so, the poet compares today with yesterday, with the past.

In this regard, it is appropriate to quote the following views of the literary scholar J. Jumabayeva. "Omon Matjon tries to show that the unjust treatment of the literature and art of each nation in the past at that time made other biggest mistakes. It is not for nothing that the poet expresses his sad and regretful thoughts through poetry "[3, 271].

It is known that Mashrab knew truth and truth as a motto throughout his life. In the poem, too, who is the lyrical hero who warns against thieves and cowardly judges? It is said that Mashrab is at the end of the rhetorical interrogation. He could not stand injustice and always defended the oppressed. He called those who were greedy to repent and love Allah. And when he saw the graves, he said, "Man, this is your destination, so why are you collecting so much wealth?" The story is told in Qissai Mashrab.
You still sleep a lot, be careful, heart

After all, sleep is the curry of the universe.

Thousands of years before it sinks

The dust of ignorance.

The wind blows the fogs away,

O Mashrab, Mashrab.

If we pay attention, the idea that the poet is trying to convey is specified in these lines. Because "too much sleep" is a sign that the Tsarist government has colonized Central Asia in the last century and deprived the people of spirituality. It is also acknowledged that if the people "sleep", they will be careless for thousands of years without achieving freedom and independence. At the same time, the poet feels himself and his people together with the spirit of Mashrab, and believes that good days will come when the clouds and fogs will dissipate in the clear sky. After all, thinking about the past, the present and the future, looking for solutions to today's problems, and most importantly, understanding and protecting people is the essence of the poetry of the poet Omon Matjon, the main goal of the lyrical hero $[1 ; 178]$.

Come, today, O poet, a tumultuous riot,

Raise controversy from different groups!

The past is slowly recovering

Raise this free flag with your people!

An honor to draw, an honor to your soul,

O Mashrab, Mashrab!

\section{CONCLUSION}

As the poet noted above, when the motherland thinks of the present of the country, its spiritual world is filled with 
worries about the plundered spiritual wealth of the people, the unappreciated culture, the disrespected human rights, the feelings. In the heart of the lyrical protagonist, the reader survives in dangerous situations, appreciates the examples of science, culture and literature that have come down to us, sheds light on the illuminated pages of today, adds to life, shares kindness to compassionate hearts tends to evoke feelings of aspiration with.

\section{REFERENCES}

1. Tursunoy Sodiqova. Mercy remains. $-T$ .: Literature and art, 1998

2. Omon Matjon. The light of faith. $-\mathrm{T}$.: Literature and art, 1992

3. Jumaboeva J. Psychological imagery in Uzbek poetry of the XX century. $-\mathrm{T}$.: Literature and art, 1998

4. Khoshimkhanov M. Mashrabi, I am honored. $-\mathrm{T}$.: Literature and art, 2004

5. www.ziyo.uz

6. Akhmedova, S. (2021). Philosophy In" Why Me" By Omon Matjon's Epic. The American Journal of Social Science and Education Innovations, 3(01), 100-104

7. Saydiyevna, A. S. (2020). OMON MATJONNING "QUSH TILI" DOSTONI GENEZISI. Сўз санъати халқаро журнали, 2(3)

8. Курбанова, Д. А. (2015). Об истории прикладного искусства Узбекистана XIX столетия и о предметах Государственного музея искусства народов Востока Российской Федерации. Молодой ученый, (10), 1513-1515

9. Азимбаев, М. С. (2014). Традиционное образование в Туркестанском крае по архивным материалам Центрального государственного архива Республики Узбекистан. Документ. Архив. История. Современность.Екатеринбург, 2014, 270-274

10. Shamsitdinova, M. (2021). Difficulties In Teaching Law Students Listening
Comprehension In English Language Teaching. The American Journal of Political Science Law and Criminology, 3(01), 1-8. 


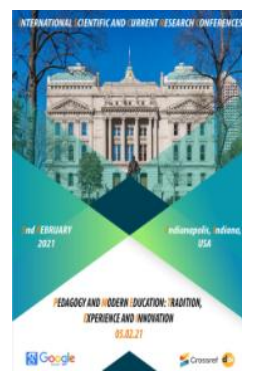

\section{Features Of Phrases In Uzbek Language}

Feruza Abdujalilova

Lecturer Uzbek Language And Literature Faculty Jizzakh State Pedagogical Institute, Uzbekistan

\section{ABSTRACT}

In this thesis, we reflect on phrases and their features in our language.

\section{KEYWORDS}

phrase polysemous language units semantic tag meaning syntactic

\section{INTRODUCTION}

Each language has its own history. In particular, Uzbek is one of the languages with a rich history. If we look at the field of phraseology of Uzbek linguistics, its formation and development was carried out by the great scholar Sh. We are sure that it is connected with Rakhmatullayev's name. At the same time, linguists YD Pinkhasov and M. Husainov contributed to the development of Uzbek phraseology (1: 456).

Phraseologisms are phrases in which there is no lexical connection between the meanings of the words and the meaning of the phrase. Phraseological confusion is based on the figurative meaning of parts, and as a result, this figurative meaning has become incomprehensible from the point of view of modern modern language. The imagery of phraseological confusions can only be revealed using historical analysis. For example, "pressing the iron in the heat".

\section{THE MAIN FINDINGS AND RESULTS}

Thus, in phraseological confusions, the connection between the original and the figurative meanings is completely lost, and the figurative meaning becomes peculiar to them. That is why it is very difficult to translate phraseological confusion into another language. Phraseological confusion has a number of unique features, which include:

1. The words in them are nowhere to be found except in confusion;

2. Confusions may include archaisms; 
PEDAGOGY AND MODERN EDUCATION: TRADITION, EXPERIENCE AND INNOVATION - INTERNATIONAL CONFERENCE

Published: February 05, 2021 | Pages: 105-107

3. They are not syntactically divided;

4. In most cases, the parts cannot be replaced;

5. They have a stable character and do not accept additional words. Words that have lost their independent lexical (lexical) meaning and become part of a phraseological complex become parts of a complex lexical compound and have the same meaning as a separate word. Therefore, phraseological confusions can be synonymous with a particular word. (2: 654)

M.Khusainov included the fourth group of idioms in the classification of phraseologies. Rakhmatullayev's contribution to the in-depth study and improvement of Uzbek phraseology on a scientific basis has been invaluable. He founded Uzbek phraseology with a series of researches. Scholar Uzbek phraseology

narrowed the scope of the phraseology and included in the phraseology only stable units based on figurative meaning (3: 231).

Uzbek linguists have also begun to deviate from VV Vinogradov's views in the interpretation of phraseology. As a result, phraseologies began to include not only stable stable compounds with a figurative meaning, but also all stable compounds that exist in the language in the form of pre-compounds and are ready to be introduced into speech. As a result, proverbs, sayings, and wise sayings began to be considered as phraseologies. (4:12) Thus, a narrow and broad understanding of phraseologies emerged.

Phraseology exists as a dialectical unit of form and content, like a word. The form of a phraseology is its appearance, and the plan of expression is called the component structure, structural structure, or material basis. The content of phraseology is its internal structure or semantics. (5: 456)

What we do know is that in recent years, a great deal of work has been done in the field of phraseology. Among the objectives of the study of phraseology are the analysis of semantic, lexical-semantic, morphological and syntactic relations. There are currently at least six classes of phraseology, which are:

1. Each of them represents the "core" of the phraseological structure - the idiom.

2. Phraseologism, which has the meaning of a complex type, is a phraseological combination that directly affects the lexical-semantic unity of the language system in terms of its structure.

3. Proverbs and sayings are units that have both direct and indirect meanings.

4. A unit with a speech pattern.

5. Phrases related to different rodv.b

\section{CONCLUSION}

So, summarizing the above, the following idea emerges. "Phraseologism is defined as a unit of language that is stable and reflective, has a distinctive character, consists of several components, is divisible and has whole meanings, and is compatible with other words" (6:54). )

\section{REFERENCES}

1. 1.Delija B. N. Phraseologie S .: 1975, S. 418

2. 2.Xusainov M. Phraseology prozypisatelnitsyAydyn, AKD, Samarkand, 1989, 24-p.

3. htpp // ziyo.net.uz / phraseology / en / 896055

4. $\quad$ http // google.uz / frazeolgiya / uz / 094090

5. That source

6. Shamsitdinova, M. (2021). Difficulties In Teaching Law Students Listening Comprehension In English Language Teaching. The American Journal of 
AND INNOVATION - INTERNATIONAL CONFERENCE

Published: February 05, 2021 | Pages: 105-107

Political Science Law and Criminology, 3(01), 1-8.

7. Rakhmatullaev Sh. Connection of verb phraseology in the Uzbek languageT .: Komuslar general editor, 1992 6-p. 


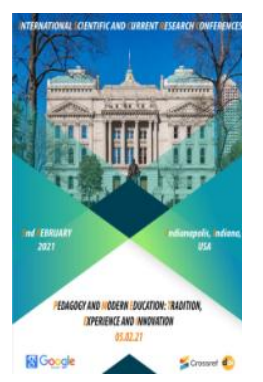

\section{Issues Of Introduction Of E-University In The Context Of Rapid Development Of Digital Technologies}

\section{I.Ergashev}

Independent Researcher Tashkent State University Of Law, Uzbekistan

\section{ABSTRACT}

This article examines the issues of introduction of e-University in the context of rapid development of digital technologies, improvement and implementation of information systems and resources, organization of electronic interaction, formation of unified electronic registers and databases. The proposals have been made for the widespread introduction of e-University.

\section{KEYWORDS}

Electronic system, electronic university, informatization, information and communication technologies.

\section{INTRODUCTION}

The Tashkent State University of Law plans to further develop legal science in Uzbekistan by attracting specialists and experts from the world's most prestigious international research centers and establishing a foresight center to conduct innovative research with the world's most famous universities. In our country, the principles of public information and freedom of information are protected by law. The state policy in the sphere of informatization is clearly defined in Article 4 of the law of the Republic of Uzbekistan "On
Informatization" ${ }^{1}$. According to this, "The state policy in the sphere of informatization is aimed at creating a national information system, taking into account the modern world principles of development and improvement of information resources, information technology and information systems". There is also a growing interest in the development of information and communication technologies, which fully embodies the

${ }^{1}$ Law of the Republic of Uzbekistan "On Informatization" on December 11, 2003 No. 560-II. Bulletin of the Oliy Majlis of the Republic of Uzbekistan, 2004, No. 1-2, Article 10. 
PEDAGOGY AND MODERN EDUCATION: TRADITION, EXPERIENCE AND INNOVATION - INTERNATIONAL CONFERENCE

Published: February 05, 2021 | Pages: 108-110

concepts of information, information resources, information technology and is now an important area at all stages of life of the state and society and citizens.

\section{THE MAIN FINDINGS AND RESULTS}

Information and communication technologies are one of the current topics and play a special role in the study of each area. It is advisable for each specialist to use modern information and communication technologies.

Modern professionals, regardless of their sphere of activity, must have a wide range of knowledge on information and communication technologies, sufficient skills in modern computer technology, information and communication systems and their use, as well as knowledge about the further development.

It should be noted that the Internet has a number of advantages over traditional Mas media. Internet is capable of combining text, image and sound at the same time; can deliver any necessary information directly to an individual or a group of individuals. As a result, it is possible to take into account the needs and desires of students; and it is interactive. Thus, it works in the form of a dialogue, not a monologue like traditional Mas media. Anyone can respond to an Internet message right awayand there is ability to transmit information quickly.

Some researchers say that the internet cannot be considered a full-fledged media outlet, citing a number of factors as the reasons for this. In conclusion, the Internet is not a single centralized media, but an environment that includes a variety of structures, including Mas media. There are also sites on the Internet whose purpose is only to disseminate information, more precisely, which is not socially insignificant.
Today the term e-university has also become more common. In short, this is the transition to an Internet-based electronic educational portal system.

The main purpose of e-university project is to increase productivity and efficiency in the management and administrative activities of university, on the basis of which to provide high quality services to students and faculty, to create an optimal environment for their activities. To achieve these goals, first of all, it is necessary to introduce innovations in the activities of the university, to reform or repeal unnecessary regulations, to shorten documents, to make decisions electronically, to establish general access to information through standardized document exchange. The implementation of this work will provide innovative services that allow students and professors to apply, receive references and other documents with the click of a button, without unnecessary hassle and bureaucratic barriers.

For example, the Decree of the President of the Republic of Uzbekistan No. 5987 "On additional measures to radically improve legal education and science in the Republic of Uzbekistan" was adopted on April 29, 2020.

According to the Decree, the creation of an open, transparent, subjective and non-abusive learning environment with the introduction of the "Electronic University" (E-University) system is identified as a particularly important task.

In order to ensure the execution of these tasks, Tashkent State University of Law has created a special innovative project platform "Electronic University", through which systematic work is being done to expand access to legal education. The World Bank has allocated \$140,000 for this project under a grant from the Academic Innovation Fund. In general, the project "Electronic University" (EUniversity) is being implemented to improve 
PEDAGOGY AND MODERN EDUCATION: TRADITION, EXPERIENCE AND INNOVATION - INTERNATIONAL CONFERENCE

Published: February 05, 2021 | Pages: 108-110

electronic document exchange and digitization of the educational process, including the formation of lesson schedules, examinations, assessment, formation of student ratings, etc.

As a result of the grant project, the most modern and innovative scientific and educational e-learning programs will be created in a single global program, such as eresearch, e-learning, e-pedagogue, e-student, e-library, e-legal propaganda through the integration into the platform, the university resources can be used from anywhere, without excessive difficulties, the introduction of the latest information and communication technologies in the educational process.

The software platforms such as "Marketing.Tsul.Uz", “Degree.Tsul.Uz", "Job.Tsul.Uz", "Topic.Tsul.Uz" and "Legalreport.Tsul.Uz" were created and launched in the framework of the project "Electronic University" at Tashkent State University of Law.

\section{CONCLUSION}

Based on the above, we can conclude the following.

1.) It is necessary to form a sufficient reserve of staff for the management of projects of the "electronic university" system, their technical organization, information security (which can respond to international hacking attacks).

2.) It is necessary to form an integrated information system among the university and its sub-organizations as a part of the introduction of the "electronic university" system.

3.) It is necessary to create an adequate infrastructure in universities for the installation and use of information systems and databases created on the basis of projects of the "electronic university" system. (Regular updating of hardware, organization of local and corporate networks, etc.).

\section{REFERENCE}

1. The Decree of the President of the Republic of Uzbekistan No. 5987 "On additional measures to radically improve legal education and science in the Republic of Uzbekistan" on April 29, 2020.

2. Law of the Republic of Uzbekistan "On Informatization" on December 11, 2003 No. 560-II. Bulletin of the Oliy Majlis of the Republic of Uzbekistan, 2004, No. 1-2, Article 10.

3. Law of the Republic of Uzbekistan "On exchange of electronic documents" on April 29, 2004 No. 611-II. Collection of Legislation of the Republic of Uzbekistan, 2004, No. 20, Article 230. 


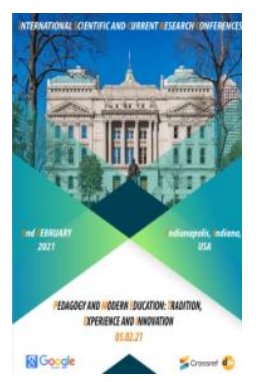

\author{
About Togay Murad's Novel “The Fields Left By My Father” \\ Lola Akhrorova Iminovna \\ Candidate Of Philology Deputy Director Of Youth Affairs Of The Academic Lyceum, \\ Jizzakh State Pedagogical Institute,, Uzbekistan
}

\title{
ABSTRACT
}

The article analyzes the novel "The fields left by my father" by the Uzbek folk writer Togay Murad, which has a unique style and content.

It includes the reasons for the tragedy that happened to a person loyal to the ideals of the communistic system of the state, a system where religious education is prohibited. In addition to this it shows the advantages and disadvantages of a cotton farmer's collective image who does not know his rights, is not interested in the surrounding society, and does not even care about his own health, which is the result of a direct social impact on the fate and behavior of a person.

\section{KEYWORDS}

Togay Murad, novel, Uzbek prose, Russian empire and the tragedies of the Soviet era, the image of an unhappy person who does not know his rights.

\section{INTRODUCTION}

The element of the subject and the contradiction of the events in Togay Murod's "The fields left by my father" novel. Togay Murod's "The fields left by my father" fiction has its own structure and meaning which is unique among novels that could describe the real life of cotton farmers.

With his prose the writer shows not only the farmer's life but also the reality which belongs to the difficulties of Uzbek cotton farmers' life. And certainly the core meaning of the fiction is the following: the destiny of the nation who constantly repeats "The patience is gold" but one never finds it. Firstly, its concept includes national and international culture relationships, secondly, the tragedy of the nation is defined originally and spectacularly. 
PEDAGOGY AND MODERN EDUCATION: TRADITION, EXPERIENCE AND INNOVATION - INTERNATIONAL CONFERENCE

Published: February 05, 2021 | Pages: 111-114

Togay Murod revealed that it is impossible to solve the whole nation's problems without alleviating their hassles, paying due to their labour and without increasing the level of economic security.

The novel begins with the following sentence: "I am the grandson of Jamaluddin hoe from Fergana". All the events and incidents are told from the words of Dehkhonkul. However, it is obviously felt that the author set a goal showing a reality by the prototype of Dehkonkul not only the ordinary life of the villagers but also he presented him as the factor which leads to the tragedy and the problems that belong to the nation.

\section{THE MAIN FINDINGS AND RESULTS}

The fiction includes 10 chapters and it is divided into 273 narratives. In addition to this, its size is 195 pages - shorter than the usual novels.

The plot of the novel, the events are given by chronological order. This kind of approach comes handy to the novelist to show the past with its epic size and to represent the hero's life, his character, and the developing process of his character at the periodic consistency. Because of this, the fiction is covered with huge vital materials.

Retrospective plot, where Dehkonkul's thoughts about his grandfather in the first chapter of the novel, about his father in the second chapter, his own childhood memories in the third chapter are written in flashback technique. In the end a reader concludes that the novel covers the hardest days of Uzbek life lasting longer than a century.

Togay Murod explores artistic influences of the social-historical conditions to the people's destiny and their personal characters. Dehkonkul is described as workaholic, conscientious, professional, naive as the most of Uzbeks and hospitable. Despite being rewarded with "October Revolution" and "Red flag of Labour" orders, you wouldn't wish being in his place on anybody.

$\mathrm{He}$ is a victim of the system in which religious education is forbidden and communistic ideas are deeply rooted in his society. His civic stance, which instilled in him the idea that a workaholic is the best person, that he thought of nothing but work, caused flaws in his character. He is an indifferent person who does not know his rights, has nothing to do with those around him, and does not even care about his own health.

Togay Murod never tries readers to feel pity about Dehkonkul, on the contrary, he shows the real condition of the hero, social environment, events which happen with him are displayed genuinely with all the difficulties of his life.. If we apply the proverb of our people "After hard work comes pleasure" to the Uzbek peasants, it will motivate us to look for the reason why the fate of peasants ended like this.

There is a common rule, artistic yarns are used less in literature devoted to historical people and events. His achievement is that he portrays almost all the events described in the novel as they were in real life, without exaggerating despite his main hero is not a historical figure. In addition to acquainting the reader with a great deal of information about the fate of historical figures of the recent past, the

creator also requires him to have related knowledge accordingly. As a result, in the imagination of the reader, the life of a farmer who has been growing cotton for almost a century and whose lifestyle has not improved, is embodied in all its complexity.

Dehkonkul and his wife's fate are shown with more details than other images of the novel, 
due to that it serves to be told as the characters have their own unique features and to be appeared as alive. The external conflict that causes the internal conflict in the family is expressed in detail and convincingly.

Unfortunately, the prose ends with the tragedy of Dehkonkul and his imprisonment for a term of eight years. Convicted Jamoliddin Dehkonkul Akbarovich will have the last words. His last request was to ask permission to "see his fields ..." which is normal for Dehkonkul, who has spent his life in the fields and has become the essence of cotton life, which is not the norm for us.

Besides only positive comments were given to this fiction by literary critics, however at some parts the difference between the subject element and the logical condition was not taken into consideration. In the novel, there is a gap in the events related to the fate and activities of the grandfather, father, grandson - three generations, as well as in the description of the system.

In our view, Togay Murod described his student period in Chapter 3, ignoring almost a quarter of a century in the middle. Another reason to say this is that: his protagonist carries a flag guiding $\mathrm{AN}-2$ plane sprinkling butyphos on a cotton field. Airplanes "Annushka" and "Kukuruznik" used in agricultural work and transportation were invented by O.K Antonov and passed the first test on August 31, 1947. They have been made in Kiev since 1949-1952's. That's why we come to this point that the events occurred within the 6o's of the last century and beyond.

The first cotton picking machine was invented in 1947 and was included in the author's novel.

As well as, on this chapter the other question comes to our mind that one of the novel's hero Akrab was died before this events which is contrary to that time and so far from the reality that his wife, Dehkonkul's mother, is obliged to pick cotton in the field of named after Stalin even thought she said many times to the officials that she was a pregnant. And the officials told her that the field did not understand what is pregnant. It is narrated that as a result Bolhin, his wife's name, picked cottons from early morning till night and earlier than its time she gave birth to a disabled child. By adding this information about the destiny of a cotton picker woman who does not know her rights the author tries to show the rudeness of the Russian Empire time, and their attitudes to women, their injustice, but he totally shut his eyes from event contradictions.

\section{CONCLUSION}

According to our theory, it could be right and better if the fourth generation was added to the novel: a grandfather, a father, grandson, his child and if Dehkonkul was greatgrandchild. If it was written as we said there were no questions as on top.

However, you want to read his novels again and again, your respect increases one more time because of his heritage to the Uzbek language and its literature that continues world and uzbek novels' traditions, his style of perfection. description of all events without

\section{REFERENCES}

1. Literary theory. 2 volumes. Volume 1 Literary work. - Tashkent: Fan, 1978. $416 \mathrm{p}$.

2. Literary theory. 2 volumes. Volume 2nd. Literary-historical process. Tashkent: Fan, 1978. - 416 p.

3. Abdulla Kahhor. Works, Six volumes, 6 vols. T,F. Gulom Publishing House of Literature and Art, T. 1971. $350 \mathrm{p}$. 
AND INNOVATION - INTERNATIONAL CONFERENCE

Published: February 05, 2021 | Pages: 111-114

4. V.Faizullah. Eternity // Togay Murod. Selected works. - Tashkent: Sharq, 2018. - 702 p.

5. Togay Murad. Selected works. Tashkent: Sharq, 2018. - 702 p.

6. Kuranov D., Mamajonov Z., Sheralieva M. Dictionary of Literary Studies. Tashkent: Akademnashr, 2010. - 397 p. 


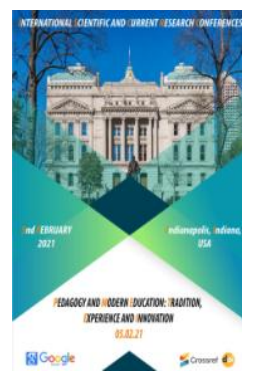

\title{
Stages Of Development Of Interaction Between Society And Nature In The Soviet Period (Late Xx - Early Xxi Century)
}

\author{
A.Sh. Kaipnazarov \\ Nukus State Pedagogical Institute, Uzbekistan
}

\section{ABSTRACT}

The article discusses the stages of studying the history of the environment in Karakalpakstan. The objectivity of the consideration of the problem is determined by the importance of solving program problems in the transitional stage of mankind to the sustainable development of society. The main task is the need for an integrated approach to solving the problems of the environmental crisis in society, combining the efforts of various organizations in solving environmental problems and the legal framework.

\section{KEYWORDS}

Environmental problems, Karakalpakstan, stages of development, society, history of interaction.

\section{INTRODUCTION}

In recent years, the formation of ecology as a science has increased the theoretical and practical importance of related earth sciences such as meteorology, climatology, hydrology, soil science, oceanology, geophysics, and geology. Also, the significance and role of related sciences, such as geography, which is aimed at presenting the full and large-scale reality of our land, but also to develop the scientific foundations for its rational use of natural resources, to form a progressive theory of environmental management, is significantly differentiated [1].
In the history of interaction between society and nature, it is necessary to consider various stages: based on socio-economic formations; by the nature of man's assimilation of natural resources, by the degree of development of productive forces, etc. In this regard, global ecology in various states of the world has creatively assimilated the most rational aspects of many sciences and scientific theories [2].

Starting from the evolutionary understanding of living nature, modern ecology at the same 
time takes into account the specifics of the anthropogenic impact on the biosphere, unprecedented in scale and nature. This impact is largely associated with the transition of the scientific and technological revolution to a higher stage of development, objectively requiring an understanding of the many contradictory processes and phenomena generated by it in nature and society and the weakening of the most dangerous of them [3].

\section{THE MAIN FINDINGS AND RESULTS}

We also note that among the most contemporary topical problems in the history of Karakalpakstan remains the issue of studying the history of the environment, which takes a priority place. From a scientific and practical point of view, the objectivity of the consideration of this problem is determined by the importance of solving program problems, especially in achieving the transitional stage of all mankind to sustainable development. As an example, one can consider dynamic changes in the natural environment of the South Aral Sea region, in particular, the drying up of the Aral Sea and the subsequent ecological crisis.

The formation of a scientifically developed environmental policy is not only a schedule of certain stages of environmental activity, but also a specific human attitude and worldview. Its implementation largely depends on how justified it is. A person with his socioecological status, his behavior, his principles should be in conjunction with the general principles of the biosphere [4].

By the end of the 2oth century, the emergence of environmental problems became so acute that they became one of the factors in the formation of general historical and social significance. Traceable feedback in the interaction of man and nature, that is, anthropogenic impact on the environment, endangers the life of modern civilization.
At the All-Union Seminar-Meeting on Nature Protection and Rational Use of Natural Resources (held at the USSR Exhibition of Economic Achievements on November 13-16, 1967), it was noted that in a number of regions of the country an extremely unfavorable situation had been created with the protection and rational use of natural resources, especially with the protection of soils, water resources, fish stocks and atmospheric air. The meeting spoke in favor of the creation of a unified state body for nature protection (and the publication of a special journal) [5].

By the beginning of the 70s there have been positive changes in the organization of environmental protection. The memorandum of the Central Laboratory for Nature Conservation of the USSR Ministry of Agriculture to the CPSU Central Committee on preparations for the UN conference on environmental problems said: the relatively recent, rather narrow concept of "nature protection" has now been transformed into the problem of scientifically based accounting, rational use reproduction and enrichment resources of the biosphere. The very same protective part of the problem was transformed not only and not so much into the protection of endangered rare species of plants and animals (which is also important), but into the science of studying ecological systems in order to predict their changes as a result of violation of permissible examples of human intervention.

In January 1988, by a joint resolution of the Central Committee of the CPSU and the USSR Council of Ministers (No. 32) "On a radical restructuring of nature protection in the country" in order to organize rational use of natural resources, implement a unified scientific and technical policy in this area and coordinate the activities of ministries and departments, a union Republican State Committee of the USSR for Nature Protection. The formation of this structure has put 
PEDAGOGY AND MODERN EDUCATION: TRADITION, EXPERIENCE AND INNOVATION - INTERNATIONAL CONFERENCE

Published: February 05, 2021 | Pages: 115-117

forward the prerequisites for the creation of environmental management [6].

In the gos of the twentieth century, new factors of complication for environmental movements appeared: the collapse of the former USSR and, as a consequence of the real system of environmental protection, the termination of many large-scale projects and programs for the improvement of the natural environment in this regard, the prevalence in public consciousness, including among members of the environmental movement are convinced of the advantages of a regionalnational way of solving environmental problems. As a result, there was sharp exacerbation of a number of contradictions inherent in the modern ecological situation [7].

\section{CONCLUSION}

Thus, concrete historical analysis allows a more objective assessment of both the experience of the past and modern problems of the relationship of the system "mansociety-nature", and this, in turn, makes it possible to more carefully approach the development of the theoretical and practical basis of ecology as a whole and social ecology in particular. As an important task of scientists from different branches of knowledge, there is a need for an integrated approach to solving the problems of the environmental crisis in society, combining the efforts of state and public organizations in solving environmental problems and the legal framework.

\section{REFERENCES}

1. Zagladin V.V. Global problems and social progress of mankind. Moscow: 1985;

2. Frolov I.T. Prospects for Ecodevelopment, Moscow: 1990.

3. Kovalev A.M. The interaction of society and nature. 1.1. , 1980;
4. Kostin A.I. Global problems of our time and the logical struggle. Moscow: 1989.

5. RGAE. f. 7486. Inventory 33, file 116, II. 11-13.

6. Theory and history. Problems of the theory of the historical process. - I., 1981;

7. Vasilyeva VN Historical development of nature management and principles of its organization. Moscow:1985; 


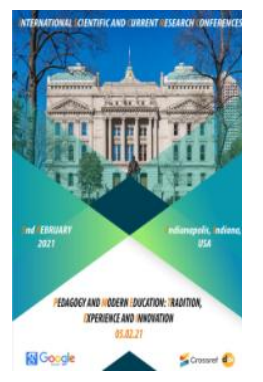

\title{
Increasing The Responsibility Of Lawyers And Ensuring The Human Right To Professional Legal Assistance
}

\author{
Shahzoda Fayzullaeva \\ Master Student Advocate Of The Law Firm “Advokat Best Legal” Tashkent State University Of \\ Law, Uzbekistan
}

\section{ABSTRACT}

This thesis is devoted to the improvement of the legislation of the Republic of Uzbekistan "On the Bar" and insurance of the liability of lawyers and lawyers to clients (individuals and legal entities receiving legal services on the basis of a contract) in order to increase their loyalty to the use of the constitutional right to qualified legal assistance.

\section{KEYWORDS}

Professional liability insurance, mistakes of attorneys and lawyers, foreign jurisdiction.

\section{INTRODUCTION}

According to article 116 of the Constitution of the Republic of Uzbekistan, the right to professional legal assistance is guaranteed at any stage of the investigation and legal proceedings. The advocacy operates to provide legal assistance to citizens, enterprises, institutions and organizations. The practice of the functioning of lawyers' formations shows that the quality of the work of lawyers has deteriorated. The number of complaints against lawyers remains high. Citizens' confidence in this institution is being lost. Complaints against lawyers from individuals and legal entities are checked by the Chamber of Lawyers and as of December
2020, complaints against lawyers account for $80 \%$ of the total number of complaints that were simply discussed, i.e. lawyers are not legally responsible. They do not compensate for damage caused by non-performance or improper performance of their professional duties. In this part, it is necessary to consider liability in the framework of legal aid treaties.

\section{THE MAIN FINDINGS AND RESULTS}

The OSCE Office for Democratic Institutions and Human Rights (ODIHR) provides support, assistance and expertise to participating States and civil society to advance democracy, 
rule of law, human rights, tolerance and nondiscrimination. ODIHR observes elections, reviews legislation, and advises governments on developing and maintaining democratic institutions. The Office conducts training programs for government and law enforcement agencies and non-governmental organizations on the protection, promotion and monitoring of human rights [8]. According to the standards for ensuring human rights developed by this institution, one of the requirements is public lawyers (and not just lawyers!), who must be bound by ensuring their liability through professional liability insurance. Most foreign jurisdictions require professional liability insurance for clients to provide professional legal assistance.

For example, in France, in accordance with the Law "On the Organization of the Bar" from 1991 professional liability insurance for lawyers is compulsory. It covers all professional mistakes of lawyers that may cause harm or loss of expected benefits for their clients or third parties. Errors may consist in violation of procedural deadlines for filing applications or appeals (violation of procedural deadlines; improper filling of documents; failure to notify third parties about the consequences of legal actions, causing harm to such persons; loss or damage to documents received by the insured person (policyholder) from the client (trustee) for the provision of legal assistance; illegal disclosure of information subject to attorney secrecy, etc.).

In the United States, each of the 52 states has its own insurance system with a predominantly individual insurance model. Only Oregon has a collective insurance system. In Georgia, lawyers are required to insure their professional compensation in the manner and in the cases provided for by law in order to compensate clients for possible material damage. In Estonia, professional insurance compensation is compulsory. Article 12 of the Swiss Federal Law on the Freedom of the Advocate Movement 2000 provides for compulsory professional liability insurance, depending on the risks associated with advocacy [8].

In Kazakhstan, in accordance with the Law of the Republic of Kazakhstan dated July 5, 2018 No. 176-VI "On advocacy and legal assistance" from January 1, 2021, lawyers and legal consultants are not entitled to provide legal assistance in the absence of a professional liability insurance contract. In accordance with the innovation:

1. A lawyer is obliged to conclude a professional liability insurance contract for obligations arising as a result of causing harm to third parties (principal), to whom, in accordance with the contract, legal assistance is provided, as a result of such assistance.

A lawyer does not have the right to start providing legal assistance in the absence of a professional liability insurance contract.

2. The object of insurance of a lawyer's professional liability is the property interests of the policyholder (insured person) related to his obligation, in the manner prescribed by the legislation of the Republic of Kazakhstan, to compensate for harm caused to third parties who, in accordance with the contract, are provided with legal assistance in connection with the implementation of advocacy.

3. An insured event under a lawyer's professional liability insurance contract is the fact of the insured's civil liability for compensation for damage caused to the property interests of third parties who are provided with legal assistance in accordance with the contract as a result of professional mistakes made by the insured person in the provision of legal assistance.

For the purposes of this article, professional errors mean:

1) Skipping due process; 
Published: February 05, 2021 | Pages: 118-121

2) Incorrect paperwork;

3) Failure to notify the person to whom legal assistance is provided in accordance with the contract about the consequences of legal actions that have caused him harm;

4) Loss or damage to documents received by the policyholder (insured person) from the client for the provision of legal assistance;

5) Unlawful disclosure of information constituting an advocate secret.

The professional liability insurance contract may determine other actions (inaction) that caused damage to the property interests of third parties (the principal), who, in accordance with the contract, are provided with legal assistance, as a result of the provision of such assistance by the insured person.

4. An insured event is considered to have occurred if the harm caused to third parties to whom, in accordance with the contract, legal assistance is provided, was the result of an unintentional violation of professional duties by the policyholder (insured person).

The procedure and other conditions for insurance of the professional liability of a lawyer are determined by agreement of the parties on the basis of a standard contract for insurance of professional liability of a lawyer [9].

The study and analysis of international standards, the experience of the countries of Europe and the CIS makes it possible to think about amending the legislation of the Republic of Uzbekistan on the legal profession in terms of civil liability insurance of a lawyer and legal consultant. Such a change will give such advantages as,

Compliance of the responsibility of a lawyer and a lawyer with the standard of democracy;
Improving the quality of services provided by

lawyers and legal consultants;

Guarantees of compensation for harm caused to the property interests of third parties (principal), who are provided with legal assistance in accordance with the contract, as a result of professional mistakes made by the insured person in the provision of legal assistance.

\section{CONCLUSION}

What is the responsibility of the legislation of the Republic of Uzbekistan on the Bar for violation of the procedure for the provision of legal assistance?

And so, according to article 14 of the Law of the Republic of Uzbekistan "On the Bar" dated December 29, 1996, No. 349-I, for violation by a lawyer of the requirements of the legislation on the legal profession, the Rules of Professional Ethics of Lawyers, advocate secrecy and the lawyer's oath entails the application of disciplinary measures to him.

Disciplinary proceedings are initiated by a decision of the qualification commission or the Higher Qualification Commission.

The grounds for initiating disciplinary proceedings are:

Revealing by the territorial administration of the Chamber of Advocates or by the justice body that a lawyer has violated the requirements of the legislation on the Bar, the Rules of Professional Ethics of Lawyers, advocate secrecy and the lawyer's oath;

Appeal of an individual or legal entity to illegal actions of a lawyer;

Issuance of a private court ruling in relation to a lawyer.

$>$ Based on the results of the consideration of disciplinary proceedings, the following 
disciplinary measures may be applied to a lawyer:

$>$ warning (based on the decision of the qualification commission);

$>$ Suspension of the license for up to six months;

$>$ Termination of the license.

And the law does not provide for who will compensate the client for damage. No insurance - no guarantee of compensation. Thus, the introduction of the practice of professional liability insurance for lawyers and lawyers in Uzbekistan will enable individuals to enjoy constitutional rights without the risk of certain harm.

\section{REFERENCES}

1. Constitution of the Republic of Uzbekistan. Tashkent: Uzbekiston, 2019

2. Law of the Republic of Uzbekistan "On the Bar" dated December 29, 1996 No. 349-I

3. https://www.osce.org/files/f/documen ts/c/c/376189.pdf

4. http://www.legislationline.org/

5. https://www.norma.uz/nashi_obzori/n e_kajdyy_yurist_-_advokat\#

6. Turdialiev, M. A., \& Komilov, B. (2020). The Legal Issues of International Investment Activity In Uzbekistan: Critical Analysis And Legal Solutions. The American Journal of Political Science Law and Criminology, 2(12), 1621.

7. Mamanazarov, S. (2021). LEGAL REGULATION OF FREELANCING IN THE REPUBLIC OF UZBEKISTAN AND ABROAD. Збірник наукових праць $\Lambda$ 'ОГО 22-25. https://doi.org/10.36074/25.12.2020.v4. 06

8. https://www.osce.org/

9. https://online.zakon.kz/ 


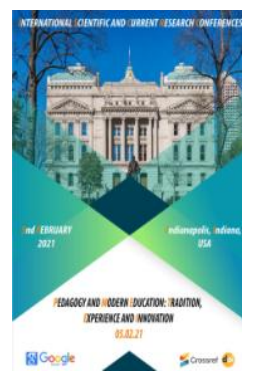

\section{The Modernization Of Education System In Uzbekistan Is A Actual Problems In Public Policy}

Umida Farxadovna Elmuratova

Assistant, The Tashkent Institute Of Textile And Light Industry, Uzbekistan

\section{ABSTRACT}

This article is revealed the important measures taken in the education system of Uzbekistan in the context of the pandemic. The state policy is analyzed on improving the quality of education, the introduction of innovations in this sphere. It justifies reforms aimed at shaping the system of innovative schools.

\section{KEYWORDS}

Education, pandemic, staff quality, innovative schools, mentality, public policy, remote areas, education.

\section{INTRODUCTION}

From the first years of his independence the Republic of Uzbekistan first and second presidents has paid particular attention to the issues of training modern creative-minded specialists, fostering the young people as patriotic and highly ethical personalities, as well as improving the education system to achieve these goals. In the world, as well as in Uzbekistan absolutely have no right to postpone work on improving the education system under the pretext of the pandemic.

Speaking about the measures taken in country to reform the school system and the urgent tasks in this area, must be emphasized words outstanding enlightener Mahmudkhuja Behbudi: "School is the greatest shrine in the world”.

During the pandemic, the educational process adjusted based on remote technologies, 500 thousand students and 7 million children from more than 10 thousand education institutions are covered by online lessons. This new mechanism ensures uninterrupted learning. Taking into account the experience of foreign countries and the current situation, it is 
PEDAGOGY AND MODERN EDUCATION: TRADITION, EXPERIENCE AND INNOVATION - INTERNATIONAL CONFERENCE

Published: February 05, 2021 | Pages: 122-124

planned to conduct online final exams at higher education institutions.

\section{THE MAIN FINDINGS AND RESULTS}

Currently, there are four Presidential and nine creative schools in Uzbekistan. This year it is planned to commission 5 more Presidential and 2 creative schools.

Due to the pandemic, the concept of social distance has firmly entered our lives. Indeed, the historical experience of developed nations shows that reforms aimed at changing the society's life began primarily with modernization of the education system. For, without changing schools it is impossible to change a person, a society. And the school is the foundation of education and upbringing, and teachers constitute its cornerstone. In the difficult years of the transition period, as it is known, the spiritual and educational environment in schools turned out to be vulnerable, the authority and prestige of the teaching profession declined, attention to the training of teachers of a new formation, the development of pedagogical science, and the introduction of innovative learning technologies decreased, which led to a number of serious problems. In recent years, large-scale reforms have been carried out to effectively address these shortcomings and to radically improve the training system. In particular, in accordance with the public education system, 6 decrees and resolutions of the President, 21 resolutions of the Cabinet of Ministers were adopted, and the legal framework for transformation in the sphere was strengthened.

Based on the wishes of parents and the general public, the 11-year school system was restored. Over the past three years, 157 new general schools have been built. Schools of a new type were organized, including those for gifted children, and those named after the great scientists Mirzo Ulugbek and Muhammad al-Khorezmi, along with literary- creative schools named after Hamid Alimjan and Zulfiya, Erkin Vahidov, Abdulla Aripov, Ibraim Yusupov, Iskhokkhon Ibrat, Muhammad Yusuf, Halima Khudoyberdiyeva, as well as Temurbeklar Maktabi schools, Presidential and private schools, which remarkably enhanced access to education.

Also, the SUE "Center for innovation, technology and strategy" under the Ministry of Public Education has been appointed the responsible organization for assessing institutions of general secondary education based on the requirements for "modern schools". General secondary education institutions that meet the requirements for "modern schools" will be issued a certificate of conformity of the appropriate level.

The document states that from March 1, 2020, the construction, reconstruction, overhaul and equipment of state institutions of general secondary education is carried out on the basis of standard construction and reconstruction projects and standards for equipping "modern schools", regardless of funding sources.

Given the importance of men's role in the education system, their participation in the effective pedagogical activities, 12 thousand 871 male teachers returned to schools as a result of specific encouragement packages taken.

Extensive work was also underway to stimulate the work of teachers. Over the past three years, their salaries have been increased by an average of 2.5 times. Clear criteria for motivating the work of teachers working in remote areas are defined; they are paid allowances of up to 50 percent. This facilitated the attraction of more than a thousand teachers to remote areas where there was a shortage of such specialists. Teachers who continue to work at retirement age was paid the full pension. 
The Concept of Public Education Development System through to 2030 was approved by a decree of the President of the Republic of Uzbekistan, signed April 29 this year. It identifies specific mechanisms for achieving 48 targets.

For example, the goal was set for Uzbekistan to join the ranks of top 30 nations of the world by 2030 in the rating of the PISA student assessment program. The Cabinet of Ministers, the ministries of finance and public education were instructed to increase the wages of public education workers in 2020. It was that a separated division created under the Cabinet of Ministers to coordinate and ensure the effectiveness of the activities of the Presidential schools and creative schools.

The necessity was noted of organizing spiritual and educational work in schools in accordance with the new system, the introduction of a single subject "Ethical enlightenment" on the basis of combining such disciplines as "National Idea", "Moral Principles", "History of Religions", "Sense of Patriotism". The importance of naming the schools with the names of prominent scientists of our people, statesmen and politicians, well-known military commanders was emphasized.

Special attention was paid to issues of upbringing in the family, parental responsibility and their cooperation with teachers. To this very end, radical reforms are undertaken lately in our education system, along with those in all areas, in order to promote comprehensive development of our country, to create a new Uzbekistan.

\section{Conclusion}

You are well aware that dozens of important decrees, resolutions and programs have been adopted on this front. Approved recently, the Law on Education will undoubtedly open new horizons in the development of this area. In accordance with the act, distance learning, inclusive forms of education are introduced, and educational institutions are allowed to establish joint faculties and training centers with foreign counterparts. Teachers are entitled to introduce their own individual syllabi and training methods, to freely opt for modern pedagogical forms, teaching and enlightenment methodologies.

\section{CONCLUSION}

In conclusion, it should be noted that in the context of the pandemic, the education system of Uzbekistan continues to be active.

\section{REFERENCES}

1. Decree of President of Uzbekistan SH. Mirziyoyev about "Strategy of actions on development of Uzbekistan for 20172021".

2. Resolution of the Cabinet of Ministers of the Republic of Uzbekistan "On the State nationwide program of school education for the years 2004-2009" (321 of June 9, 2004)

3. Resolution of the Cabinet of Ministers of the Republic of Uzbekistan "On further improvement of system of training and re-training of teachers» ( 25 of 16 February 2006).

4. Resolution of President Shavkat Mirziyoyev "On the establishment of presidential schools" (February 20, 2019). 


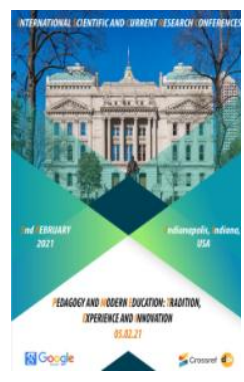

\title{
Morpho-Biological Properties Of Hibiscus Syriacus L. And Hibiscus Hybrid
}

\author{
Allaberdiev R.X. \\ National University Of Uzbekistan Jizzakh State Pedagogical Institute National University Of \\ Uzbekistan \\ Raximova M. \\ National University Of Uzbekistan Jizzakh State Pedagogical Institute National University Of \\ Uzbekistan \\ Esov R.A. \\ National University Of Uzbekistan Jizzakh State Pedagogical Institute National University Of \\ Uzbekistan
}

\begin{abstract}
In the next period of advanced science and technology, the situation requires attention to improving the ecological situation, managing the balance of nature, creating a favorable ecological environment for the population, improving the climate of large cities and so on.
\end{abstract}

\section{KEYWORDS}

HIBISCUS HYBRID Rusanov Flora

\section{INTRODUCTION}

In the next period of advanced science and technology, the situation requires attention to improving the ecological situation, managing the balance of nature, creating a favorable ecological environment for the population, improving the climate of large cities and so on. On the basis of the instructions of paragraph 3 of the minutes of the meeting of the Cabinet of Ministers "On measures to accelerate the reconstruction of the city of Urgench 01-05 / 1$833 "$ The need to increase the number of ornamental plants "Hibiscus" in the landscaping of the city of Urgench, Khorezm region, was noted by the leadership of our government.
There are currently about 200 forms and varieties of hibiscus. Hibiscus began to grow in the botanical gardens of European countries in the early XVIII century. Hibiscus (Hibiscus) is a plant belonging to the family Hibiscus, which grows mainly in tropical regions of Southeast Asia. Hibiscus is a shrub or small tree up to $3 \mathrm{~m}$ tall. It covers about 300 species.

Institute of Flora and Fauna gene pool of the Academy of Sciences of the Republic of Uzbekistan named after F.N. Rusanov, Hibiscus has been grown as an ornamental plant since 1940. 
PEDAGOGY AND MODERN EDUCATION: TRADITION, EXPERIENCE AND INNOVATION - INTERNATIONAL CONFERENCE

Published: February 05, 2021 | Pages: 125-128

Object of research: Hibiscus syriacus L. and Hibiscus hybrida species of the family Malvaceae.

H. syriacus L. (Syrian hibiscus) is native to China, India. A deciduous shrub with light green leaves and flowers of different colors. In landscaping it is possible to grow it individually and in groups, to build green walls or alleys. Syrian hibiscus grows slowly, begins to bloom in 3-4 years. Lives up to 100 years. With age, it becomes more resistant to cold and can withstand temperatures down to 220C. Syrian hibiscus grows well in moderate humidity (does not like calcareous soil), resistant to transplanting and pruning. In early spring the old and old branches are cut, the very long branches are shortened. Syrian hibiscus grows well from cuttings, grafting and seeds. Widely used in landscaping in Uzbekistan.

Hibiscus hybrida or (Cotton flower) was developed in the 40-50s of the last century by the well-known breeder F.N. Rusanov. A perennial ornamental plant. Demands heat and humidity. Hibiscus flowers are large, longblooming. Very attractive flowers - simple, large, up to $15-20 \mathrm{~cm}$ in diameter. Hibiscus hybrida flowers vary in color and size. The flowers are white, white-yellow, rose-colored, red, pink, nastarin (siren), purple varieties. Hibiscus hybrida is characterized by landscape, rapid growth, adaptability to different climates. Hibiscus hybrida is one of the perennial plants that blooms for a long time in warm regions and blooms from the first decade of June until frost. Hibiscus hybrida is less demanding to soil.

But it grows well in well-drained soils. Hibiscus hybrida is resistant to gas and smoke and can be used in urban landscaping. Hibiscus hybrida seeds retain their viability for 3-4 years and require a temperature of $20-240 \mathrm{~S}$ for the seeds to germinate. Seeds germinate 9-12 days after sowing. Hibiscus hybrida is shade tolerant, but in the absence of light development slows down and blooms less. Relatively drought tolerant, grows and thrives well in open, sunny areas. In winter, the above-ground branches of hibiscus dry out. Strong roots overwinter in the soil - new shoots sprout forth the following year.

At present, a $\mathrm{H}$. hybrid nursery has been established in the Botanical Garden, the seeds of which ripen in late August and early September and are harvested at this time. Hibiscus seeds are sown in spring (MarchApril). Seeds are not stratified before sowing, they are sown directly. The sown seeds are finely sprinkled with $0.5 \mathrm{~cm}$ of sand in spring and $1.0 \mathrm{~cm}$ in autumn. wood chips on top of the sand, covered with manure. When the top of the seed is covered with sand, etc., the thickness should not exceed $1.5-2.0 \mathrm{~cm}$. Then lightly watered with a watering can. Seeds are easy to germinate and can be stored for 3-4 years. 1 pog. per meter is sown 4-5g of seeds, it is not necessary to shade the seedlings.

Hibiscus is also easily propagated vegetatively, i.e. by cuttings, rootstocks and grafting. In autumn, hybrid hibiscus bodies are cut, leaving $8-10 \mathrm{~cm}$ from the ground, and covered with soil, humus or sawdust, and in spring the bottom is opened. Hybrids of hybrids are propagated by planting, separating the branches from the bushes (in the spring the buds swell). Propagated by green cuttings in spring and early summer.

Hybrid varieties of hibiscus are propagated vegetatively, that is, by division of the bush, by pruning and grafting. In the first case, the cultivation of hibiscus begins with this - in the spring in late April is dug up an adult bush (with twigs), from which the soil is removed, divided into several parts. It is necessary to have roots and growth point in the allotted part. Divided plant branches are planted.

Cuttings should be prepared in early spring before the arrival of hot days. Usually the branches close to the root collar are cut or 
separated from it by the heel. The separated area should be cleaned with a knife. Cuttings prepared in this way should be $10-15 \mathrm{~cm}$ long and $6-8 \mathrm{~mm}$ in diameter. Planted cuttings are sprayed with water 3-4 times a day, and the plant is rooted for $3-4$ weeks.

In summer, hibiscus is well watered, softened when the top layer of soil dries, fed regularly. From time to time it is necessary to spray the surface of the hibiscus to remove dust. Protected from diseases and pests. After watering, the soil is loosened. In autumn, watering is reduced.

They can grow in one place for several years. Hibiscus is a perennial shrub that is drought tolerant, but this negatively affects their flowering. If the plant is not watered enough, it may lose some of its flower buds. Therefore, hibiscus needs special care during the scorching heat of the year. It should be watered once or twice a week (the more it is watered, the better). Irrigated areas are sprinkled with peat humus or straw. Even though his body is strong, he needs to be tied up.

Hibiscus is fed with complete mineral fertilizers. It is considered to be well fertilized even if it is watered from time to time by mixing manure (juice) with water. Hibiscus is fed once a week from spring to mid-August, the rest is fed half a dose of phosphorus and potassium once a month.

With the onset of cold, hybrid hibiscus bodies are cut, leaving $8-10 \mathrm{~cm}$ above the ground, and covered with wood or rice chips, dry peat humus or manure. Hibiscus grows well and blooms for a long time when properly and regularly cared for.

Thus, the results obtained on the basis of many years of scientific experience of scientific institutions of the republic in the cultivation and propagation of hibiscus flowers are reflected.

\section{REFERENCES}

1. Kurbanova, D. A. (2016). ANCIENT PEARLS IN GREAT WORLD MUSEUMS WHICH BELONG TO THE HISTORY OF UZBEKISTAN AND LEARNING THEM. Социосфера, (3), 55-61.

2. Mukhamajanovich, S. S., Gayratovna, S. S., \& Ravshanovich, G. M. (2020). The use of the mountain kars in the tourism sphere in cort and recreation zone of Chimgan-Charvak. Journal of Critical Reviews, 7(3), 475-481.

3. Alibekov L, Alibekova S, Hazarov I, Gudalov M. About some regularities of degradation geosystems in Central Asia. Tatranka Javorina, Slovakia, 2012, Vol 21, № $-1,42-44 r$

4. 4.Gudalov M. Foundation of AydarArnasay lakes system and their effects on the environmental landscape. Nature and Science.Volume 17, Number 11 November 25, 2019 USA New York.

5. 5.Gudalov M., Zikirov B. Metnods of studying the landscapes around the Aydar-Arnasay lake system. International engineering journal for research \& development. Vol - 5, Issue - 7, 2020 India.

6. 6.Gudalov M., Zikirov B., Imamova D. Predicting changes in landscares around the Aydar-Arnasay lake system. Accerted in the journal The American of Engineering and Technology. Volume - 02, Issue - 10, October 2020.

7. 7.Gudalov M., Gozieva M. Ways to develor modern ecoturism in the Zamin basin. International engineering journal for research \& development. Vol - 5, Issue - 7, 2020 India.

8. 8.Sharipov Sh, Gudalov M, Shomurodova Sh. Geolologic situation in the AydarArnasay colony and its atropny. Journal of Critical Reviews. Volume 7, Issue 3, 2020 Malaysia Kuala Lumpur.

9. 9.Sharipov Sh, Shomurodova Sh, Gudalov $M$. The use of the mountain in the tourism sphere in cort and recreation zone of Chimgan-Charvak. Journal of 
AND INNOVATION - INTERNATIONAL CONFERENCE

Published: February 05, 2021 | Pages: 125-128

Critical Reviews. Volume 7, Issue 3, 2020 Malaysia Kuala Lumpur.

10. Kurbanova, D. (2020). Tent Of The Emir Of Bukhara (Second Half Of The 19th Century)(History Of One Exhibit From The Collection Of The State Hermitage). The American Journal of Social Science and Education Innovations, 2 ;(12), 180-183. 


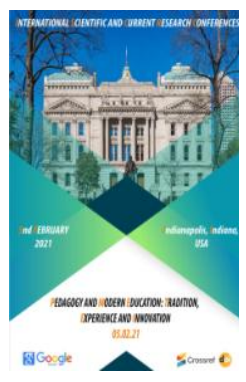

\title{
Artistic Interpretation Of Events In Nadira Poetry
}

\author{
Eshonkulova Surayyo Isomiddinovna \\ Doctor Of Philosophy, Associate Professor Of The Department Of Uzbek Language And \\ Literature, Jizzakh State Pedagogical Institute, Jizzakh 130100, Uzbekistan
}

\section{ABSTRACT}

This tezis is devoted to an analysis of the artistic depiction of life events in Nodira's poetry; to transmission of her philosophical views to further generations on how a kind ruler, a true beloved, loving father, perfect man should be, through creating the image of his fiance Umarkhan.

\section{KEYWORDS}

Nadira, divan, Umarkhan, lyrical image, firoknoma poems about parting), genre.

\section{INTRODUCTION}

In the poetry of Nadira, the images of historical figures living in her era and associated mainly with the history of the religion of Islam are reflected in poetic form. The literary critic M.Kodirova, in an appendix to the publication of Nadira's divan in 1963, gives more than forty historical and mythical images used in the poems of the poetess [7, 621]. It is also known that the scholar, based on new perspectives, assessed the images of historical figures in the lyrics of Nadira [5, 112].

The most common used historical image in the poetry of Nadira is undoubtedly the image of her husband, Khan of Kokand - Amir Umarkhan. The prologue to Komila divan, for example, also proves this statement. There she writes about the memories associated with Umarkhan:

"She is shy, confessed, and deprived of the right to seek love. She is among lovers. She acted according to Sharia, and had a pseudonym Komila. She expresses and sets out her condition that for a long time in a separation she was alarmed from the anxieties of separation. And there was restlessness from pain in the heart because of separation. Since, like a flower and a fruit of the tree of noble origin, the mentor of the poor, and important sultans, Sayid Muhammad Umar Bahadirkhan (may he rest in 
the grace of the Allah) was her support on the throne of union of love and was an ally on the throne of consensus. For some time, she was happy in conversation with her majesty and was protected from the seizures of accidents. In the palace of conjunction, she was happy, and on the throne of communication was powerful with the enjoyment of life and joy. She was glad from the happiness of seeing the face of the Sultan and was proud meeting him. Content of the beit:

Oh, how good it is, those days when at the feast of the union of lovers I was glad,

From the happiness to see, his joyful and cheerful face, I was proud.

Neither there was sadness from separation in the heart, nor suffering from the pain of parting in the soul. From the shine of his face, her eyes were clear and her heart was happy and joyful. The sun of her honor rose from the east of greatness and dignity. Her sun, happiness, and states shine in the palace of reign, her dominance was clear to all partials; the nobility was obvious to all the people. And even their dominance was connected with the Emir's clan, maybe for this reason dominance passed to their clan." [8, 19-20].

Based on the above examples, Z. Kobilova concludes that Amiriy (the pen name of Umarkhan) "seems to us to be a good family man, a sincere person" $[4,38]$. M. Kodirova writes about the family environment of two creative personalities: "We can say that love reigned in the family of Nadira and Umarkhan. Amiriy is known as a lyric poet and statesman. All readers know the work of Nadira, and the well-being of her family. However, readers were not presented in a holistic form that the family life of Umarkhan and Nadira was based on a deep sense of love, joyful minutes of raising children, and sad feelings of Nadira after the death of Umarkhan. Because in the recent past it was quite difficult to talk not only about the personal qualities of Umarkhan and his role in the family, but also about the initiations written by Nadira in honor of the deceased husband " $[5,19]$.

The sources contain valuable information about the poet's love for Amir Umarkhan: "This great lady, pure in heart, faithful, pious, rare pearl from the sea of nobility and knowledge, cherishing the welfare of the state, during the period of the mentioned Khanate and emirates, when the oppression of fate became infinite, when fidelity was so rare when humanity and condescension remained only their definition, remained faithful and sincerely devoted to her life partner Amir until the end of their life " [3, 32].

Erstwhile, Uvaysi wrote about the mutual feelings of Nadira and Umarkhan. Content:

He is Yusuf, she is Zuleikh.

He is Vomik - she is Uzro.

She is Leili, he is Majnun.

In love with each other [6, 21].

M.Kodirova writes that the mutual feeling of love between two artistic personalities was also reflected in the following lines of Amiriy. Content:

If the soul rejoices in the native land,

Recklessness is given to a loving soul

Drinking a cup of love at a fun feast

Always a cup of red wine thirsts for the soul.

M.Kodirova also writes that the lines "Glory to Allah, the flower of favor and love blossomed" were written in response to rubai of Umarkhan [5, 21-22].

"Regarding the artistic relationship between Nadira and Amiriy, it can be noted that there are a number of legends about the pure love 
and fidelity of these famous personalities, their mutual respect, life in peace and harmony, a poetic contest. And the presence of such traditions is to some extent justified. For example, in one of the legends, a romantic event sets out a life event that served as the reason for writing the famous ghazal by Amiriy, beginning with the lines. Content:

Do not touch the eyebrow with a pencil

Do not spoil the word with one letter.

The legend says that these lines are written in relation to Nadira ... "[1, 178$]$.

The literary scholar also points out that: "In the works of Nadira, Umarkhan is represented mainly in three guises:

1) beloved man, beloved father, majestic, spiritually mature, physically strong man;

2) an accomplished artistic personality, an excellent poet, a caring mentor and a generous patron;

3) a fair, kind, ambitious ruler, by the definition of the poetess - "sahibkiran" ... " [1, 181].

From the above comparisons, it cannot be concluded that the life of the poetess and the khan has always been cloudless. Among the poems of Mokhlaroyim (the real name of the poetess of Nadira) there are such motives as the bitterness of separation, infidelity, the heartlessness of the beloved. Though, of course, it cannot be argued that the lyrical hero of all Nadira's poems is the prototype of Umarkhan and that poetry on the separation, infidelity and censure of a loved one is dedicated to him $[2,46]$.

Many of them are a traditional interpretation of love lyrics. Nevertheless, in most poems of the poetess her emotional feelings and attitude to reality are felt.
Poems dedicated to Umarkhan can conditionally be qualified in the following order:

1. Chanting of the khan.

2. Accusations of separation, estrangement and infidelity.

3. Mentorship on ruling the government.

4. Firoknoma (Poems about separation).

The traditions of eastern literature are continued in Nodira's "Firoknoma" and the subtle hearty experiences of an unmarried woman are effectively illuminated. In the examined "Firoknoma", the center of attention is not traditional as in "marsiya" genre - the images of a lover, friend, loving father, and another lyrical hero - but it focuses at a woman who has lost her beloved man as a lyrical hero" [8, 88]. Indeed, in "Firoknoma" love, the bitterness of separation is often mentioned.

Another aspect of the "Firoknoma"- in the works written after the death of Umarkhan, Mokhlaroyim reflected her pleas for a better future for her children. And therefore, poems of such a plan deserve attention because they include the call of the heart of the poetess as a mother and a woman. In particular, her state of mind after her husband's death, her desire to see support in her children, her appeal to the Almighty with a request to give children happiness and a long life are described in the ghazal with "Yo rab" radif. Content:

Darling, left this world as pure as morning

With your mercy, may him rest in peace, oh my God.

The grave of my benefactor, the sanctuary of the universe,

With your mercy, may it be like Kaba to him, oh my God. 
PEDAGOGY AND MODERN EDUCATION: TRADITION, EXPERIENCE AND INNOVATION - INTERNATIONAL CONFERENCE

Published: February 05, 2021 | Pages: 129-132

Let the young khan to live a very old age,

Make his life longer than all nations, oh my God.

Make it true also for an honest emir Mahmud Aminkhan, and their children too,

Make these three a friend of yours till the end of the world, oh my God. [8, 51-52].

Her wishes towards sons are also reflected in the ghazal, beginning with the lines. Content:

In the days of the righteous khan, hundreds of thanks to him

It has become completely peaceful time.

In the ghazal, Nadira acts both as a mother and as a female politician, thinking about the future of the state. This appears in the beit. Content:

Khans with recognition say to you: well done,

Persistent sultan himself supports you with a love in his soul. [9, 128-129].

So the poetess once again illuminates the relations of Umarkhan and the Ottoman sultans who patronize him and hints that they can be relied upon while maintaining the stability of the state.

We can say that with regard to the historical images of her era, the leading place in the work of the poetess is occupied by the image of Umarkhan. When portraying the image of Umarkhan, the poetess used two completely different positions:

1) a woman who is faithful to her beloved, overwhelmed with a sense of pride in his achievements, suffering from separation from him;
2) a wise politician who puts the interests and future of the state and nation above the interests of one person.

In conclusion, we can draw the following observations. Nadira's poems dedicated to Amir Umarkhan can be studied by dividing into the following groups: 1) glorifying the khan; 2) accused of separation and infidelity; 3) instructions for managing the state; 4) firoknoma. The poems of this cycle are also significant in that they give an artistic interpretation of the events of their life as a poetess.

Moreover, we also became convinced that Nodira was twofold in relation to her children. In the first case, she is a mother who loves her children infinitely, in the second she is a wise adviser, constantly urging children not to stay away from the fate of the people and nation.

\section{REFERENCES}

1. Abdugafurov A. Values in the depths of the heart. -T.: Teacher, 1998.

2. Jurakhonov A. The image of Umarkhan in Nodira's lyrics // Uzbek language and literature, 1997. - № 5.

3. Kodirova M. Nadira (essay on life and work). - T.: Science, 1967.

4. Kobilova Z. Amir and his literary activity: PhD diss. - T.: 2007.

5. Kodirova M. Queen of Poetry and Love. -T.: Literature and art, 1998.

6. Amiriy. Divan. The Museum of Literature of the Republic of Uzbekistan, Manuscript No. 403.

7. Nodira. Divan. -T.: Science, 1963.

8. Nodira-Komila. Divan. -T.: Folk heritage, 2001.

9. Nodira-Komila. Divan. -T.: The National Library of Uzbekistan, 2004. 


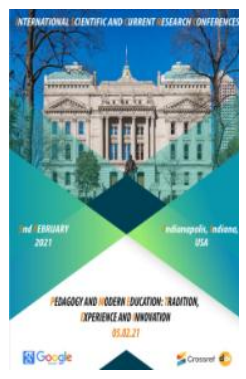

\section{On The History Of Training Of Cartographers In Uzbekistan (20s-30s Of The XX Century)}

Primov Mukhiddinjon Omonovich

Doctorate Student Of National University Of Uzbekistan

\section{ABSTRACT}

The article is devoted to the study of the work done in Uzbekistan in the field of cartography in the 20-30s of the XX century, the creation of educational maps and network atlases. The article describes the emergence of cartographic scientists, scientific societies and institutions engaged in cartography, the problems in their activities, information on the shortcomings.

\section{KEYWORDS}

Geodesy, cartography, USSR, Aerial Photography, Cartography Engineers, Land Cadastre, Aerial Survey, the Great Soviet Atlas, geobotanical maps, small-scale maps, Sredazvodkhoz, cotton sovkhozes

\section{INTRODUCTION}

The great achievements in the development of Soviet cartography are mainly due to the thorough training of personnel, the organization of systematic scientific research and, consequently, the formation of cartography as an independent science. In 1917 the Faculty of Geodesy was opened at the USSR Landscape Institute, and in 1923 the first higher school of cartography appeared.

Another condition for the growth of cartographic production was the development of equipment and new methods of work that would increase labor productivity. Aviation photography has undergone radical changes in topographic work and geographical research. Its systematic introduction into production in the USSR dates back to 1923, when the first aviation research company was established. Aerial photography has helped to significantly increase labor productivity; the opportunity to conduct specific research in areas that were previously difficult to access; finally opened up new ways of enriching and improving topographic and thematic maps due to the 
PEDAGOGY AND MODERN EDUCATION: TRADITION, EXPERIENCE AND INNOVATION - INTERNATIONAL CONFERENCE

Published: February 05, 2021 | Pages: 133-136

objectivity of aerial photography and the clear presentation of the interrelationships between the various elements of the landscape[5].

The first higher school of cartography in the Union was established in 1923 at the Faculty of Geodesy of the Moscow Institute of Land Cadastre (now the Moscow Institute of Geodesy, Aerial Photography and Cartography Engineers) and in 1929-1930 at the Department of Geography of Moscow and Leningrad Universities. The opening of cartography specialties allowed cartographers to have a broader understanding of engineering training, cartography production technology. Although there is a certain difference between the two schools of cartography, they were based on the general idea that if a cartographer does not understand the essence of any area on a map, he cannot describe it correctly unless he sees its characteristic features. Later, the training of specialist cartographers was organized in other universities.

The research activity, which initially developed mainly in higher education, was further strengthened in 1928 with the establishment of the Central Research Institute of Geodesy, Aerial Survey and Cartography, as well as other research institutes.

All this contributed to the formation of cartography as a special field of knowledge. In the 1920s, his tasks included the development of scientific and technical methods and processes for compiling and reproducing maps, which was a major step forward compared to previous pure geometric interpretations of cartography. However, while more emphasis was placed on mapping methods, the study of their nature was overshadowed, although it was important to develop their methods, collect, analyze, and evaluate resources to create new maps. This difference was especially noticeable when Soviet cartography began to create major cartographic works, such as the Great Soviet Atlas of the World.

Prominent figures in Soviet science were the surveyor F.N. Krasovsky and the geographer A.A. Borzov's influence ensured that cartographers were trained on a solid geodetic and geographical basis. In 1929-1930, cartographic work expanded rapidly, and cartographic specialties were established in the geography departments of Moscow and Leningrad universities.

In 1930 the Faculty of Geodesy of the Institute of Land Cadastre was merged with the Moscow Institute of Geodesy, then in 1936 the Moscow Institute of Geodesy, Aerial Photography and Cartography Engineers was merged with the Faculty of Special Cartography. Later, training of cartographers was organized in other universities. Secondary qualified cartographers graduated from topographic technical schools with cartographic departments.

From the late 1930 s onwards, cartography began to be considered as a science that studied cartographic maps (as a special method of representing reality) and processes[4]. All this contributed to the formation and development of cartography as a science.

Significant work has been done in Uzbekistan in this regard. In particular, the Central Asian State University (now the National University of Uzbekistan) in the 1920 s created original geological, hydrogeological, soil-geobotanical and other maps based on scientific imagination, which played an important role in thematic cartography not only in Uzbekistan but also in Central Asia. In particular, in 1920-1932, the Institute of Soil Science and Geobotany at the University compiled soil and vegetation maps of almost the entire territory of Uzbekistan on the basis of field expedition materials[3]. In 1923, the institute staff N.A. Dimo, R.I. Abolin, M.A. 
PEDAGOGY AND MODERN EDUCATION: TRADITION, EXPERIENCE AND INNOVATION - INTERNATIONAL CONFERENCE

Published: February 05, 2021 | Pages: 133-136

Orlov, M.N. Voskresenskiy, K.M. Klavdienko compiled the first survey soil map of Central Asia at a scale of 1: 1,000,000. This card was reworked in 1927 and was also exhibited at the Washington International Congress. From 1920 to 1931, the institute conducted more than 150 expeditions in Central Asia, compiling special soil and plant maps with scales of 1, 2, 5, 10, and scales of 1:50 000, 1: $100000,1: 500$ 000 , most of them on a colored background, published topographically.

In 1926, scientists from Central Asian State University received a B.A. Fedchenko and O.E. Knorring created the Turkestan Vegetation Map, one of the first geobotanical maps of the Soviet era. E.P. Korovin also developed a 1: 3,000,000 scale map of Central Asia and South Kazakhstan in 1933. In the 1930s, this work continued and I.I. Granitov and Sh.M. Agababyan Uzbek Plants 1: 500,000 scale, I.I. Granitov developed geobotanical maps of the South-West Kyzylkum vegetation at a scale of 1: 200,000. Published in 1926, D.V. Nalivkin's book "Essays on the Geology of Turkestan" includes a 40-gauge geological map.

The development of methods of stereo drawing of relief by Soviet scientists and the creation of a number of photogrammetric instruments necessary for this played a major role in the development of the science of cartography. The development of cartographic work has led to the growth of topographic knowledge of the country. Numerous sheets of topographic maps at scales of 1:25 000, 1:50 000 and 1: 100000 were produced, while various special and general geographical maps of medium and small scale were created to meet the different needs of the national economy. In 1927, a reference map of the European part of the USSR was published at a scale of 1: 1,500,000, and in 1929, a map of the Asian part of the USSR was published horizontally at a scale of 1: 5,000,000. These maps served as reference maps for various institutions and were the basis for other small-scale maps. After that, work will begin on the creation of 1: 500,000 and 1: 1000000 scale maps and a number of special maps, in particular geological and economic maps. In 1929, the "Industrial Atlas of the USSR" was published with a collection of maps for various industries[2].

While the Central Asian republics were very simply depicted on all maps until the 1920s, there were almost no maps about our country. Therefore, the work on creating new cards has begun. However, due to the fact that the work was not carried out in an organized manner and the plan was not followed, the necessary documents arrived late. Some of them are considered to be inaccurate, which leads to errors in the direction. Lack of contracts, urgency and uncertain numbers have led to unnecessary costs. A clear example is the mistakes of the Sredazvodkhoz (Central Asian Water Resources) administration. The lack of groundwater drawings would have affected crop yields in the organization of the necessary irrigation works. It was necessary to ensure the accuracy of economic statistical work in order to correct errors and properly organize topogeodesic work. Because these reports were conducted separately, the areas given to the organizations in general were not photographed. Some areas were photographed two or three times. Most of the pictures could not be used because they were taken at the wrong scale[6].

In the late 20 s and early 30 s of the XX century, scientists of the USSR Institute of Soil Science and Geobotany M.A. Orlov Uzbekistan's, M.A. Pankov Tajikistan's, K.M. Klavdienko created survey soil maps of Karakalpakstan, Turkmenistan and Kyrgyzstan, and the whole of Central Asia. According to N.V. Kimberg, in 1931-1932, the staff of the institute drew 1: 100,000 scale soil maps of about 30 cotton sovkhozes (200,000 hectares) in Central Asia[1]. 
In short, Uzbekistan in the period up to the 30 s of the XX century has not yet been fully studied in a comprehensive way. This was due to the insufficient formation of local cartographic personnel, the lack of typological views about the components of nature, the fact that they form a whole on the basis of natural-geographical laws, and that they are constantly interacting. As a result, mapping in perfect condition was not scientifically possible. However, the research served as a conceptual basis for future perfect maps.

\section{REFERENCES}

1. Galkov Ch.V., Rahimbekov R.U., Yugay R.L. Maps of Uzbekistan. - Tashkent: Teacher, 1975. - P. 96-97.

2. Garaevskaya L.S. Cartography. - M.: Nedra, 1971. - P. 330.

3. Rahimbekov R.U. From the history of studying the nature of Central Asia. Tashkent: Teacher, 1970. - P. 71-87.

4. Salishchev K.A. Cartography. - $M$.: Vysshaya shkola, 1982. - P. 257.

5. Salishchev K.A. Kartovedenie. $-M$.: Publishing house of Moscow University, 1990. - P. 369.

6. NAUz R-9 fund, list 1, case 1520, page 19. 


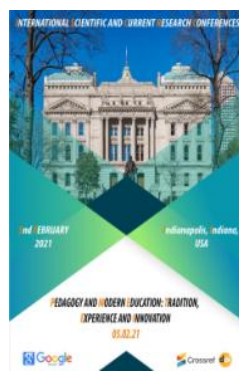

\section{Requirements For The Adoption And Administration Of An Administrative Document (Act) By Public Administration Bodies}

Javlon Karimjon O'G'Li Zoilboev

Lecturer Department Of Administrative And Financial Law, Tashkent State University Of Law, Uzbekistan

\section{ABSTRACT}

The article analyzes the most urgent and problematic aspects of the administrative document adoption phase, which is considered the main process in the activities of the bodies of state achievement, administrative bodies.

\section{KEYWORDS}

Public administration, document, administrative body, rights, democratic reform

\section{INTRODUCTION}

Each state body, including public administration bodies, administrative bodies that carry out management, in the course of its activities enter into relations with third parties. This relationship is directly and indirectly related to any event affecting the rights and interests of individuals and legal entities. In this situation, the administrative body, because of its activities, that is, activities related to the provision of public services to individuals and legal entities, will have to adopt an official document based on specific facts and legal grounds. With this document, the applicant may have a certain right, change or become invalid.

\section{MAIN PART}

The fundamental essence of the reforms carried out in the Republic of Uzbekistan and, ultimately, for the purpose of ensuring the rights and freedoms of citizens, further liberalization of the entrepreneurial environment, formation of the personality of each layer of the population from the state, further raising their confidence for the next day, is an indicator of awakening the nature of initiative. In this regard, many works are being conducted in the field of Public Administration, in particular in connection with the organization of administrative bodies, modernization of powers and 
PEDAGOGY AND MODERN EDUCATION: TRADITION, EXPERIENCE AND INNOVATION - INTERNATIONAL CONFERENCE

Published: February 05, 2021| Pages: 137-141

functions, the legal power of documents that are not in the normative acts adopted by them, their practical application.

The basis of these reforms is reflected in the decrees of the president of the Republic of Uzbekistan "On the strategy of actions for the further development of the Republic of Uzbekistan," "On the concept of Administrative Reforms in the Republic of Uzbekistan," and normative-legal acts such as the laws of the Republic of Uzbekistan "On administrative procedures."

In particular, it is appropriate to touch on the reforms conducted in accordance with the "Priority directions of improving the system of state and society construction" and the second direction "Priority directions of ensuring the rule of Law and further reform of the judicial and legal system " $[1]$, which is considered the first direction of the strategy of action. Socio-political implementation of the laws adopted in these directions, numerous works are being conducted to radically improve the quality of the activity of law-making activities, directing its impact on the process of socio-economic and judiciallegal reforms.

Simultaneously, it is thought of to centralize public administration, raise the status of civil servants, the level of professional training, and reform the system of public administration bodies. In addition, changes are being introduced in the field of ensuring the openness of activities of state authorities and management bodies, ensuring effective rights and freedoms of individuals and legal entities, as well as the legitimate interests.

The adoption of the decree of the president of the Republic of Uzbekistan "On the concept of Administrative Reforms in the Republic of Uzbekistan" adopted as a result of reforms in this regard [2] and the adoption of the laws of the Republic of Uzbekistan "On administrative procedures" and the work carried out in the field of Public Administration with the help of normative-legal documents. If we say that with the law of the Republic of Uzbekistan "On administrative procedures" a new system has entered the legislation of the Republic of Uzbekistan, there is no exaggeration.

In this law to the administrative bodies "In the field of administrative and legal activity, the bodies to which administrative management is authorized, including public administration bodies, local executive authorities, selfgovernment bodies of citizens, as well as other organizations and specially formed commissions authorized to conduct this activity, and the administrative document is intended to establish public legal relations of the administrative body, for some individuals or legal entities aimed at changing or liquidating, or for a group of persons to be separated by certain private signs, certain legal consequences have been described as a measure of impacting [3], and their procedures have also been individually regulated. According to the explanations of the lawyer scientists, The administrative document is a document that is accepted because of the actions of the administrative body in the field of administrative and legal activity in relation to individuals and legal entities [4] and which imposes an obligation on individuals, cancels or modifies it. Additionally, in accordance with "Administrative Procedure Act" (Verwaltungsverfahrensgesetz, VwVfG) : An administrative act shall be any order, decision or other sovereign measure taken by an authority to regulate an individual case in the sphere of public law and intended to have a direct, external legal effect. A general order shall be an administrative act directed at a group of people defined or definable on the basis of general characteristics or relating to the public law aspect of a matter or its use by the public at large . I. I. Maskayeva, considering the concept of "administrative act" as an" external expression of will", 
particularly touches on the question that it is important to express the power of authority.

As an example, we can cite a document on the registration of business enterprises, a license, a permit, documents (decisions) of local government bodies. Here, it is expedient not to refer to the documents in the normative act. In this regard, it is appropriate to bring individual features of the administrative document.

The main features of the administrative document are:

- The administrative document is accepted by the administrative body;

- The administrative document is closely related to public legal relations;

- $\quad$ Administrative document establishes, changes or terminates public legal relations;

- $\quad$ An administrative document is drawn up for a particular individual or legal entity, or for a community of several persons;

- $\quad$ Administrative document generates certain legal consequences.

Based on these features, it is also necessary to give the requirements for this document. The law of the Republic of Uzbekistan "On Administrative Procedures" According to article 53: the administrative document must be legal, reasonable, fair, accurate and understandable. The existence of these requirements is explained by the fact that the administrative document should not create any difficulties for individuals and legal entities to which it is directed. Because it is individuals and legal entities that are the plaintiffs of the adopted administrative document. In addition, in accordance with the law[5], an administrative document must contain:

1) the name of the administrative document and the date of its acceptance;
2) administrative hujjatni the name and location (postal address of the receiving administrative body);

3) information on participants in administrative proceedings;

4) description (part of the description of the issue to be solved through the administrative document);

5) the basis (substantive part of the administrative document);

6) statement of the decision taken (summary part);

7) the period and procedure for filing a complaint against the administrative document;

8) the position, name and surname of the official (members of the collegial body) adopted by the administrative body. Accurate and complete indication of this information not only ensures stability in the activities of the administrative body, but also guarantees the execution and implementation of the administrative document.

The importance of administrative act is evident in its four aspects:

1. The material is considered significant. Through administrative acts, administrative management and regulation become more convenient.

2. Procedural significance. During the adoption of the act, of course, administrative organs follow to certain laws. These rules are expressed in the laws of the states "On administrative procedures."

3. It is considered significant in terms of its focus on performance. Through administrative ICT, the administrative bodies will be able to conduct direct execution actions within the framework of their powers.

4. The importance of administrative court proceedings. The administrative act and its content, the legality of which will later be 
considered a fact, if a dispute arises, the Administrative Court will be the most important object of contention in the proceedings[6].

At the same time, based on statistical data, we can say that in recent years, local government authorities, in particular khokimiyats, have adopted administrative documents, including decisions of local khokimiyats by courts invalid for 9 months of 2020: the total number of cases considered was 2,422, of which 1110 cases were invalidated by acts of local khokimiyats, 971 cases were refused, in 215 cases the proceedings were terminated, in 126 cases left without consideration). From this, it can be seen that in most cases, the practical application of the requirements to the administrative document is still lame. To avoid such negative consequences, in all respects it is advisable that only and exclusively administrative bodies ensure the legality of their activities.

\section{CONCLUSION}

In conclusion, we can say that the administrative document expresses the competence, power of the judicial authority of the administrative body. This document is considered to reflect the activities of the state aimed at regulating a particular sphere. At the same time, the administrative document also establishes certain rights for citizens, it can change the rights or abolish it. In this respect, both the state body and the citizens must actively participate in the process that the administration accepts. That is, the administrative document that will be accepted will be perfect in all respects.

\section{REFERENCES}

1. Collection of legislative acts of the Republic of Uzbekistan, 11.12.2019y 06/19/5892/4134-number.
2. The collection of legislation of the Republic of Uzbekistan, 19.03.2020-y., 06/20/5968/00331-number.

3. The national database of legislation data, 09.01.2018-y., 03/18/457/0525San; 07.01.2020-y., 03/20/600/0023number.

4. S.A.Muratayev, B.T.Musayev, D.R.Artikov. Ma'muriy huquq va protsess. - Toshkent: Toshkent davlat yuridik universiteti, 2020. B. 373

5. National database of legislation data, 09.01.2018-y. 03/18/457/0525-San; 07.01.2020-y., 03/20/600/0023-number

6. Nematov J.N. Ma'muriy akt - ma'muriy huquqning markaziy institute: qiyisoyhuquqiy tahlil. Monografiya/J.Nematov. - T.: Top Image Media, 2021. p- 18-19. UDK 342.924(035.3)(575.1)

7. https://stat.sud.uz/file/2018-2019-20209\%20oylik/сайт\%2омаъмурий.pdf

8. O'G'Li, Zoilboev Javlon Karimjon."Administrative Reforms In The Republic Of Uzbekistan: Some Problems and Prospects." The American Journal of Political Science Law and Criminology 2.12 (2020): 1-4.

9. Ахроров, А. (2021). ТЕНДЕНЦИИ УПРОЩЕНИЯ ПРОЦЕДУР ЛИЦЕНЗИРОВАНИЯ И РАЗРЕШЕНИЯ В РЕСПУБЛИКЕ УЗБЕКИСТАН. Збірник наукових праць SCIENTIA.

10. Abdusattarova D., Yusupov S. Improvement of Organizational and Judicial Frameworks of State Bodies with Appeals of Legal and Physical Entities //Архив научных исследований. - 2019.

11. Yusupov S. B. The right to the treatment and its evolution //European Journal of Humanities and Social Sciences. - 2016. - №. 1. - C. 72-73.

12. Yusupov S. B. THE ESSENCE AND ACTIVITY OF THE INSTITUTE OF THE TREATMENTS OF PHYSICAL AND LEGAL ENTITIES IN STATE BODIES OF THE REPUBLIC OF UZBEKISTAN 
Published: February 05, 2021 | Pages: 137-141

//Theoretical \& Applied Science. - 2015.

- №. 11. - C. 140-143.

13. ЮСУПОВ С. Б. СОВЕРШЕНСТВОВАНИЕ

ОРГАНИЗАЦИОННО-ПРАВОВЫХ

OCHOB

ОСУЩЕСТВЛЕНИЯ

ПРАВОВОЙ ПОЛИТИКИ СО

СТОРОНЫ ГОСУДАРСТВЕННЫХ

ОРГАНОВ HA MECTAX //Review of law

sciences. - 2020. - №. 4.

14. Юсупов С. Б. Институт обращений физических и юридических лиц в Узбекистане: развитие и современное состояние //Государственная власть и местное самоуправление. - 2017. - №. 5. - С. 36-38.

15. Ю.Саидазимов, МАЪМУРИЙ ОРГАНЛАР ТОМОНИДАН ДИСКРЕЦИОН ВАКОЛАТНИ ҚЎЛЛАШНИНГ ЎЗИГА ХОС ХУСУСИЯТЛАРИ. Бакалавриат ва магистратура талабаларининг илмий ишлари // Халқаро масофавий илмийамалий конференция якунлари бўйича илмий ишлар тўплами. Тошкент: ТДЮУ, 2020. - 5626.

16. Y.Saidazimov ADVOKATLIK FAOLIYATI TASHKILIY TUZILMASI HISOBLANGAN ADVOKATLIK BYUROSINING TASHKILIY-HUQUQIY MAQOMI VA TUZILISHIDAGI AYRIM MASALALAR “Юридик фанлар ахборотномаси Вестник юридический наук - Review of law sciences" илмий-амалий хуқуқий журнали Ўзбекистон матбуот ва ахборот агентлигида 2017 йил 18 августда о931-сонли гувохнома билан давлат рўйхатидан ўтказилган. 